\title{
EFEITOS DA APLICAÇÃO DE MICRONUTRIENTES E DE NIVEIS DE CALAGEM EM QUATRO LEGUMINOSAS FORRAGEIRAS TROPICAIS
}

\author{
FRANCISCO ANTONIO MONTEIRO
}

Orientador: Prof. EURÍPEDES MALAVOLTA

\begin{abstract}
Dissertação apresentada à Escola Superior de
Agricultura "Luiz de Queiroz", da Universidade de São Paulo, para obtenção do título de Mestre em Solos e Nutrição de Plantas.
\end{abstract}

PIRACICABA

Estado de São Paulo - Brasil

Sotembro, 1980 
Aos meus pais, por terem me dado a vida e o máximo de si pela minha educação e

As minhas irmãs, pela satisfação de: tê-las

$$
\text { o fereço }
$$

\author{
A minha esposa Marisa, com quem pelo amor \\ felizmente me uni, e \\ A Juliana, fruto desse amor e \\ felicidade maior do \\ nosso lar
}




\section{AGRADECIMENTOS}

São apresentados os sinceros agradecimentos às seguintes pessoas e Instituições:

- Ao Prof. Dr. Euripedes Malavolta pelas orientações seguras, ensinamentos e atenção dedicadas à nossa pessoa.

- Ao Engo Agro PhD Joaquim Carlos Werner pela transmissão de conhecimentos técnicos e pela forma fraterna com que sempre nos distinguiu.

- Ao Engo Agro Dr. Edgard Leone Caielli, Diretor Geral do Instituto de Zootecnia, pelas facilidades concedidas.

- Ao Engo Agro Geraldo Leme da Rocha pela oportunidade de aperfeiçoamento e incentivo prestado.

- Aos Engos Agrọs Dr. Josē Vicente Silveira Pedrei ra e Dr. Herbert Barbosa de Mattos pelo apoio à realização do trabalho.

- Aos amigos do Instituto de Zootecnia, e em espe cial ao grupo da Seção de Nutrição de Plantas Forrageiras, pe la colaboração prestada.

- Ao Estat. Antonio Alvaro Duarte de 0liveira, pe la colaboração durante as anālises estatísticas.

- Aos Engos Agros Dr. Bernardo Van Raij e Dr. Alcyr Cesar do Nascimento pela colaboração na fase de anālises de solo. 
- Aos professores da Area de Solos e Nutrição de Plantas da ESALQ pelos ensinamentos ministrados.

- Aos Senhores Rodolfo Leandro Mauerberg, Luís Muscio e Antonio Marco Pigatto pela ajuda em värias etapas do trabalho.

- A Senhorita Fernanda Meconi, Senhora Sandra Apa parecida Folegatti Zanini e Senhor José Bonetto pela colabora ção durante as anālises em laboratōrio.

- A Senhora Maria Alice Crestani pela ajuda na tabulação dos dados e datilografia do trabalho.

- A minha esposa Marisa e à minha filha Juliana pelo sacrifício e compreensão sempre prestados.

- A Bibl. Maria Elisabeth Ferreira de Carvalho pe la ajuda na citação de literatura.

- As funcionārias da Seção de Pōs-Graduação da ESALQ pela amizade e distinção sempre manifestadas.

- A Companhia Industrial e Comercial Brasileira de Produtos Alimentares (NESTLE) pela ajuda financeira.

- Ao Conselho Nacional de Desenvolvimento Cientifico e Tecnológico pela concessão de uma bolsa de pesquisa no ano $75 / 76$.

- E a todos que, de alguma forma, contribuiram pa ra a realização do presente trabalho. 
I NDI CE

Página

RESUMO . $v i$ i

SUMMARY $x$

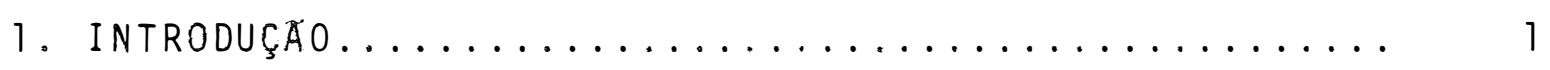

2. REVisao de Literatura................... 4

2.1. Calagem...................... 4

2.1.1. Acidez e necessidade de calagem em

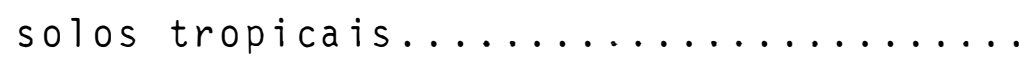

2.1.2. Efeitos da acidez do solo em leguminosas........................ 6

2.1.3. Respostas das leguminosas forrage ras tropicais à calagem............. 10

2.2. Micronutrientes................... 23

2.2.1. Micronutrientes para leguminosas....... 24

2.2.2. Respostas das leguminosas forrageiras tropicais à aplicação de micronutrientes no solo............... 26

3. MATERIAL E METODOS........................ 39

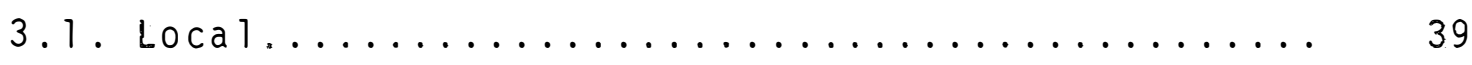

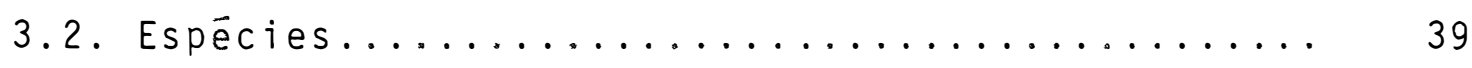

3.3. Solo ........................... 40

3.4. Preparação dos vasos e calagem............. 40

3.5. Plantio, adubação, irrigação e desbastes...... 41

3.6. Delineamento experimental............. 42 
Pāgina

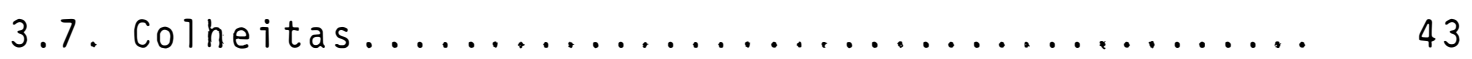

3.8. Amostragens de solo.................... 44

3.9. Anälises químicas das plantas.............. 45

3.10. Anālises químicas de solos................ 46

3.11 . Anāitises estatîsticas................. 47

4. RESULTADOS E DISCUSSÄO.................... 49

4.1. Efeitos quimicos da calagem no solo.......... 49

4.2. Efeitos da calagem nas leguminosas........... 54

4.2.1. Soja perene var. Tinaroo............ 54

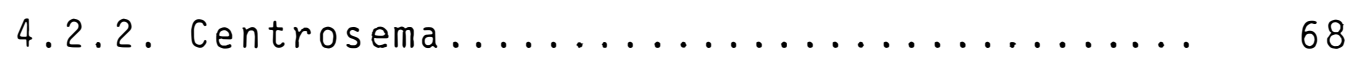

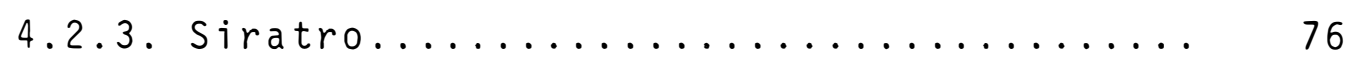

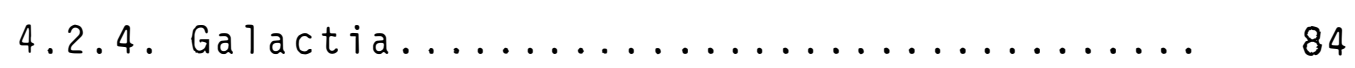

4.3. Efeitos dos micronutrientes nas leguminosas.... 96

4.3.1. Soja perene var. Tinaroo............ 96

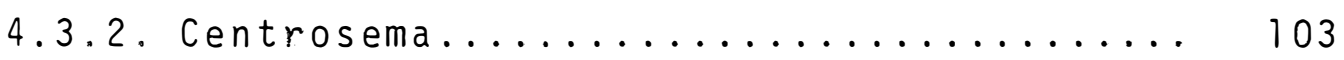

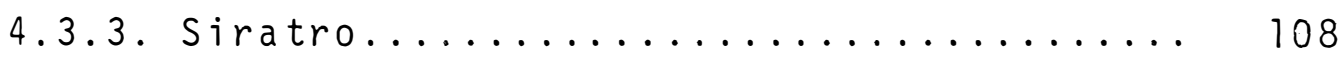

4.3.4.Galactia........................113

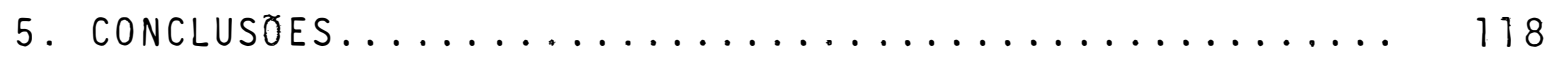

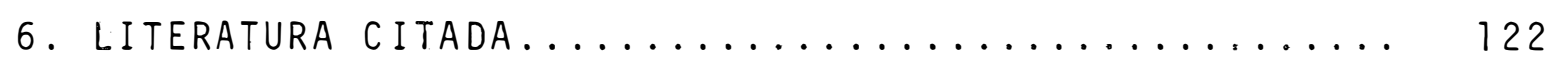

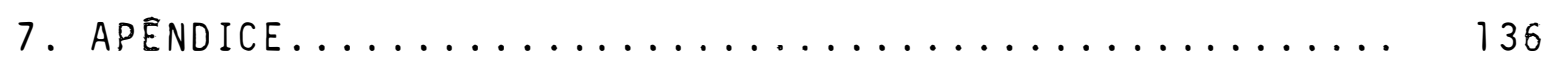




\section{EFEITOS DA APLICAÇAOO DE MICRONUTRIENTES E DE NIVEIS DE CALAGEM EM QUATRO LEGUMINOSAS FORRAGEIRAS TROPICAIS}

Francisco Antonio Monteiro Orientador: Prof. Euripedes Malavolta

RESUMO

o presente trabalho foi desenvolvido com o objetivo de estudar a influēncia de micronutrientes e de nĩveis de calagem na produção de matéria seca, na nodulação, na quantidą de de nitrogēnio fixada e na composição mineral de soja perene Tinaroo (Glycine wightii (R. Grah. ex Wight \& Arn) Verdc. var. Tinaroo), centrosema (Centrosema pubescens Benth), siratro (Ma croptilium atropurpureum D.C. CV. siratro) e galactia (Galac tia striata (Jacq.) Urb.).

o experimento foi conduzido em vasos, em casa-de - vegetação situada na Estação Experimental Central do Instituto de Zootecnia, em Nova Odessa, Estado de São Paulo. Utilizou -se um solo Podzōlico Vermelho Amarelo - variação Laras Alico e foram testados quatro níveis de calagem $(0 ; 0,83 ; \quad 1,66$ e 
2,49 toneladas de calcário dolomítico por hectare). Dentro de cada nivel de calagem estudou-se o efeito de molibdenio ou boro + cobre + zinco (aplicados conjuntamente), segundo a técnica do fatorial. Os dezesseis tratamentos obtidos foram dispostos em blocos ao acaso, com trés repetições.

A aplicação do calcário dolomítico foi realizada cerca de 42 dias antes do plantio das espécies enquanto os micronutrientes foram aplicados na forma de solução e momentos a pós o plantio, em 19.03.75. Realizou-se uma adubação básica, em todos os vasos, com fósforo, potássio e enxofre.

Em 12.05.75 efetuou-se o corte único do siratro e o primeiro corte da soja perene e da galactia. A centrosema sofreu o ünico corte em 02.06 .75 enquanto o segundo corte da soja perene foi realizado em 23.06.75 e o da galactia em 30.06 .75 .

A produção de matéria seca, nodulação e nitrogènio total da soja perene e da centrosema foram crescentes até a maior dose de calcārio aplicada. Os valores máximos para essas variäveis e nessas espēcies, seriam obtidos com níveis de calagem superiores aos empregados. Em ausência de calagem, a soja perene exibiu sintomas visuais de toxidez de manganés.

Para o siratro os máximos valores da quantidade total de nitrogénio seriam obtidos com o emprego de uma tonela da de calcário por hectare, enquanto para a galactia no segundo corte esses vaiores máximos ocorreriam mediante a aplicação de 0,72 toneladas do corretivo por hectare. Relacionaram-se es 
ses pontos de máximo com os resultados das anālises químicas do solo.

Entre os micronutrientes, o molibdēnio foi o que proporcionou as respostas mais favoráveis para as leguminosas testadas e seus efeitos somente ocorreram quando se aplicou cal cārio. As doses de calcário em que ocorreram as respostas ao mo libdēnio variaram de uma espēcie para outra.

0 emprego de boro, cobre e zinco em conjunto apenas mostrou efeitos positivos, para o siratro e quando em pre sença da maior dose de calcário aplicada.

A calagem resultou em variações significativas na composição mineral das leguminosas enquanto a aplicação de boro, cobre e zinco juntos proporcionou elevação nos teores de boro em todas as leguminosas estudadas e em presença de qualquer dos níveis de calcário. 


\section{EFFECTS OF LIMING AND MICRONUTRIENT ADDITION \\ ON FOUR TROPICAL FORAGE LEGUMES}

Francisco Antonio Monteiro

Adviser : Prof. Eurípedes Malavolta

SUMMARY

This experiment was carried out in order to study the effects of 1 iming and micronutrient addition on dry mat ter yield, amount of nitrogen fixed and on the mineral composi tion of perennial soybean (Glycine wightie (R. Grah. ex Wight \& Arn.) Verdc. var. Tinaroo, centro (Centrosema pubescens Benth), siratro (Macroptilium atropurpureum D.C. cv. siratro) and galactia (Galactia striata (Jacq.) Urb.) under controlled conditions.

Plants were grown in pots containing a Red-yellow Podzolic Soil Laras variation. Four levels of dolomitic li mestone were applied $(0,0.83,1.66$ and 2.49 tons per hectare) before planting. Each limestone level was split intofour treat ments consisting of a combination of Mo and B plus Cu plus Zn, arranged in a factorial design. Three replications were used. 
A basal dressing of $\mathrm{P}_{2} \mathrm{O}_{5}, \mathrm{~K}_{2} \mathrm{O}$ and $\mathrm{S}$ was used in all pots.

Centro and siratro received only one cutting whe reas two were performed in perennial soybean and galactia.

It was found that dry matter yield, nodulation and total amount of nitrogen fixed of perennial soybean and centro increased with lime rates. Maximum values were to be expected with levels higher than the maximum used in the experiment. Symptoms of Mn toxicity were observed in perennial soy bean in the absence of 1 ime.

In the case of siratro the highest amount of nitrogen was observed to occur when 1 ton of 1 imestone per hecta re was used. In the second cutting of galactia maximum value of total amount of nitrogen would occur when 0.72 tons of $1 j$ mestone per hectare had been applied. These points of maximum were correlated with the results of soil analysis.

Molybdenum caused the most significant responses, always in the presence of limestone. The rates of limestone which allowed for the molybdenum effect varied according to the species.

Joint application of $B, C u$ and $Z n$ showed favoura ble effect only for siratro and in the presence of the highest level of limestone.

Liming brought about significant changes in the mineral composition of the forages, whereas the joint application of $B, C u$ and $Z n$ caused an increase in $B$ concentration in all legumes irrespective of the level of limestone. 
1. INTRODUÇAOO

Tradicionalmente as leguminosas tem sido utili zadas na agricultura, especialmente nas regiões temperadas. Nas ültimas décadas o emprego de plantas dessa famîlia nas āreas tropicais tem se mostrado perfeitamente viāvel e bem su cedida.

E ponto bem estabelecido que o fornecimento de nitrogēnio, de forma adequada e contínua, constitui-se num fa tor chave na melhoria da produtividade e do valor nutritivo de uma pastagem.

Alternativamente, esse nitrogènio pode ser acrescentado à pastagem através do emprego de adubo mineral ou do aproveitamento do potencial de fixação biológica do nitrogênio, pelas leguminosas forrageiras. Dada a problemática 
atual da produção do adubo nitrogenado a partir de derivados do petróleo, grande ènfase se tem dado à pesquisa com leguminosas forrageiras.

Entre os vārios fatores que afetam a fixação de nitrogênio pelas leguminosas, um dos principais ē a nutrição mineral do sistema leguminosa-Rhiz•bium. No contexto da nutrição mineral os aspectos relativos à calagem e ao emprego de micronutrientes nos solos tropicais tem sido enfatizados.

A afirmação de que "não hā justificativa para propor que as leguminosas tropicais precisem de calagem porque o solo é ácido, pois elas são capazes de prosperar e nodu lar quase normalmente em solos nitidamente ácidos" não é nova (NORRIS, 1958). Para acrescentar à afirmação, ANDREW e NORRIS (1961), ao comparar o desenvolvimento de leguminosas tropicais e o de temperadas, tambēm apresentaram nítida evidência de que o grupo das tropicais tolera mais as condições de solos ácidos que o das temperadas.

Todavia, MUNNS e FOX (1977), trabalharam com maior nümero de espēcies tropicais e de temperadas e verifica ram não haver distinta diferença entre os dois grupos, estando a resposta à calagem mais diretamente ligada à espécie con siderada.

A reconhecida variação da disponibilidade dos micronutrientes em função das condições de acidez do meio bem realçam a necessidade de estudos em que se relacionem ambos os fatores e se deixe clara a posição de um quando se obtém a 
resposta com o outro.

Dentro desse contexto de resposta controvertida à calagem e da necessidade de obtenção de dados para micró nutrientes quando se relaciona calagem com micronutrientes pa ra leguminosas forrageiras tropicais é que se desenvolveu o presente trabalho. Nele se procurou estudar quatro legumino sas forrageiras situadas entre as mais indicadas por JONES (1974) para as condições do Estado de São Paulo.

0 presente trabalho, desenvolvido com um solo de distribuição expressiva na região de estudo, tevie por obje tivos:

- observar a influência de quatro níveis de calagem e de quatro micronutrientes na produção de matēria seca, na no dulação, no nitrogênio fixado e nos teores de macro e micronutrientes de quatro leguminosas forrageiras tropicais.

- determinar a real necessidade de calagem e de aplicação de micronutrientes dentro de cada nivel de calagem, para cada uma das leguminosas.

- verificar as possíveís alterações quïmicas no solo resultantes do emprego do calcário dolomitico. 
2. REVISÁO DE LITERATURA

2.1. Calagem.

2.1.1. Acidez e necessidade de calagem em solos trop $\underline{i}$ cais.

De acordo com MALAVOLTA (1976), admite-se atua I mente que a acidez do solo é constituída pela fração trocāvel correspondente ao aluminio adsorvido ao complexo de troca e pela fração titulāvel devida ao ĩon hidrogènio ligado à matéria orgānica e, possivelmente, aos polímeros de alumínio. YUAN (1963) trabalhou com solos da Flörida e estabeleceu que em condições de elevada acidez hā predomināncia dos ions hidrogénio sobre o aluminio; com o aumento do pH - aluminio passa a predominar sobre o hidrogēnio e acima de pH 5, 8 ambos tornam-se insignificantes. 
Para COLEMAN e THOMAS (1967) o alumīnio trocável é o cátion dominante nas condições de solo ảcido, com o que concordam KAMPRATH (1970 e 1972) e MALAVOLTA (1976).

TISDALE e NELSON (1975) mostram que a hidrólise do alumīnio é a responsável pelo baixo pH das soluções con tendo o ion aluminio.

Existe uma série de métodos de se determinar a necessidade de calagem dos solos (COLEMAN e THOMAS, 1967; CATANI e ALONSO, 1969; DEFELIPO et a 1 ii, 1972; WERNER e MATTOS, 1972, VAN RAIJ, 1975 e MALAVOLTA, 1976). Entre eles, o método da incubação de amostras do solo com quantidades crescentes de carbonato de cálcio ou óxidos de cálcio e de magnésio, com posterior leitura do $\mathrm{pH}$, tem sido um dos aconselhados (CATANI e ALONSO, 1969; DEFELIPO et alii, 1972; WERNER e MATTOS, 1972 e MALAVOLTA, 1976). Geralmente, por esse método procura-se atingir o pH 6,5 (MALAVOLTA, 1976) e, através desse procedimen to normalmente se obtém necessidades de calcārio maiores que por outros métodos comuns (CATANI e ALONSO, 1969).

A multiplicação do teor de aluminio trocável do solo por um fator 1,5 ou 2,0 (VAN RAIJ, 1975 e MALAVOLTA, 1976) tem sido amplamente usada no Estado de São Paulo, para avaliar a necessidade de calagem para uma série enorme de cuI turas.

A calagem tem como um dos papéis o de elevaros teores de cálcio e de magnésio do solo. Dentro dessa premissa, VAN RAIJ (1975) propõe a adoção de um valor 2 (solos de textú 
ra leve e com baixo teor de matéria orgānica) ou 3 (para os demais solos) para se subtrair o valor encontrado para a soma de cālcio e magnésio na anālise química do solo e assim se fí xar a quantidade de calcārio necessāria.

2.1.2. Efeitos da acidez do solo em leguminosas.

De acordo com JACKSON (1967) os diversos fatores da acidez do solo que afetam o desenvolvimento das plantas são o pH do solo, o alumínio trocāvel, as bases trocāveis, o manganês solūvel e a disponibilidade de nutrientes às plantas. Acrescenta ainda, que a separação entre a ação desses fá tores é difícil, dada a sua interdependéncia.

ANDREW (1976), trabalhando com cinco leguminosas tropicais e seis temperadas verificou que a nodulação e o subsequente crescimento da leguminosa teve efeito dominante do ion hidrogēnio sobre o cálcio, que o efeito benêfico do cálcio somente foi notado dentro de certa faixa de pH e que o pH teve pequeno efeito nas plantas bem supridas com nitrogé nio combinado.

Apōs revisar uma sērie de trabalhos

ANDREW

(1978) afirma que as leguminosas diferem na sua habilidade de nodular em substratos com variáveis valores de pH e suprimento de cālcio e que o crescimento ōtimo bem como a māxima produção de nitrogênio são dependentes de pH e nível de cālcio satisfatōrios.

A nutrição em cālcio tanto da planta hospedeira como do Rhizobium è extremamente complexa (ANDREW, 1962). 
Para MUNNS (1970) o inīcio da infecção das raízes pelos Rhizó bia é a fase que mais exige cālcio na nodulação da leguminosa. Acrescenta ainda que uma vez iniciada aquela fase em meio com adequado suprimento de cālcio, os nōdulos se desenvolvem normalmente mesmo que a planta seja removida para uma solução com baixa concentração de cālcio.

A influência do cálcio para o crescimento do Rhizobium foi estudada por NORRIS (1959) que mostrou ser esse elemento requerido em muito pequenas quantidades por esse microrganismo. Todavia, deixou evidente ser o magnésio essencial e exigido em maiores quantidades que o cálcio para o nor mal desenvolvimento do Rhizobium.

Com relação ao magnēsio, Michael citado por ANDREW (1962) obteve aumentos na produção de proteina e no ta manho dos nódulos quando empregou esse macronutriente para o cultivo de uma espécie do gènero Phaseolus.

De acordo com KAMPRATH (1972) nas condições de solo àcido o molibdénio tende a ser firmemente preso pelas a gilas e óxidos hidratados de ferro e aluminio, podendo sua disponibilidade às plantas ser inadequada. Neste aspecto, SIQUEIRA e VELOSO (1978) trabalhando com nove solos do cerrado brasileiro, verificaram que a máxima adsorção do molibdato ocorreu nas proximidades de $\mathrm{pH} 4,0$ e que acima de $\mathrm{pH} 6,0$ a adsorção tornou-se muito baixa.

ASHER (1979) descreve o aumento da disponibili dade do molibdēnio e a redução da capacidade de absorção des- 
se elemento pelas raỉzes da planta, com a elevação do pH. Acrescenta que o incremento na disponibilidade $\bar{e}$ de magnitude maior que a redução daquela capacidade da planta, de tal forma que a quantidade do elemento absorvida pela planta aumenta com a elevação do pH.

LINDSAY (1972) discute a variação da solubilidade dos micronutrientes boro, cobre, ferro, manganés e zinco em função do pH do meio. Mostra que a solubilidade desses nutrientes, em geral, tem máximos valores em pH baixo $(4,0$ a $5,0)$ e que essa solubilidade decresce com a elevação do pH, embora esse decréscimo tenha proporções diferentes para cada um dos elementos discutidos.

0 efeito depressivo do excesso de aluminio para as plantas tem sido ressaltado hä algumas décadas (ANDREW, 1962 e KAMPRATH, 1972). Para RORISON (1958) o excesso de alumīnio é especialmente prejudicial à leguminosa no desenvolvimento da plàntula e o principal efeito negativo desse excesso estā na inibição do crescimento radicular.

ANDREW et alii (1973) estudaram os efeitos do emprego de quatro nĩveis de alumīnio $(0 ; 0,5 ; 1,0$ e 2,0ppm de A1) em solução nutritiva onde cultivaram cinco leguminosas for rageiras tropicais e seis temperadas. Constataram, dentro de ambos os grupos, espécies que não tiveram suas produções de matéria seca afetadas por qualquer dos nîveis de alumínio empregados; outras em que o efeito prejudicial foi ressaltado somente na mäxima dose de aluminio e outras ainda que foram 
negativamente afetadas a partir do nível $0,5 \mathrm{ppm}$.

Conforme ANDREW (1978) a toxidez de manganês o corre mais comumente nas leguminosas que em plantas de outras famîlias. O mesmo autor afirma que a toxidez de manganés exer ce sua maior influência na germinação e no desenvolvimento da nascediça.

ANDREW e HEGARTY (1969) cultivaram oito legumi nosas forrageiras tropicais e quatro temperadas, em solução nutritiva recebendo seis nî̀veis de manganês $(0,5 ; 2,5 ; 5,0$; $10,0 ; 20,0$ e 40,0 ppm de $M n)$. Verificaram não haver diferença de tolerância ao excesso de manganês entre os dois grupos de leguminosas, mas dentro de cada grupo constataram ampla varia ção na produção de matēria seca como resultado do emprego des se micronutriente. No grupo das tropicais, em geral, marcan tes decrēscimos na produção de matēria seca e concomitantes aumentos na concentração de manganês na parte aẻrea foram observados nos niveis de 10 ou mais partes por milhão de manganês.

SOUTO e DÖBEREINER (1969) testaram a aplicação de quatro níveis de manganès $(0 ; 50 ; 100$ e 200 ppm de $\mathrm{Mn})$ a um solo da baixada fluminense, no qual cultivaram seis legumi nosas forrageiras tropicais. Puderam observar, já aos 22 dias apōs a semeadura, a maior ou menor sensibilidade das espécies ao excesso de manganés no solo. Essas diferenças entre as espécies foram ressaltadas por ocasião do corte do experimento. Também constataram que a dose de $50 \mathrm{ppm} M n$ jā reduziu conside 
ravelmente o peso de nōdulos e o nitrogênio fixado pelas leguminosas. Neste aspecto, FRANCO e DÖBEREINER (1971) verificaram que a nodulação e a fixação de nitrogênio foram mais sensiveis à toxidez de manganès do que a produção de matéria seca da soja.

Sintomas tỉpicos da toxidez de manganès em le guminosas forrageiras são descritos por SOUTO e DÖBEREINER (1969) e ANDREW e PIETERS (1970).

2.1.3. Respostas das leguminosas forrageiras tropicais à calagem.

Dentro do contexto do presente trabalho a tónica desse item é para o estudo dos efeitos resultantes da calagem quando aplicada a solos cultivados com a soja perene, centrosema, siratro ou galactia.

2.1.3.1. Estudos com a soja perene.

0 efeito do calcário aplicado em doses de 0 ;

4; 6 e 8 toneladas por hectare a um solo de cerrado no qual cultivaram a soja perene, foi estudado por NEME e LOVADINI (1967). O pH do solo ao final do ensaio foi de 4,21; 5,05; 5,55 e 5,56 enquanto a produção total de matéria seca da soja perene teve indices 100; 169; 154 e 214 para as respectivas doses de calcārio. Acréscimos na produção de matéria seca da soja perene também foram obtidos por RIBEIRO et alii (1970), num solo com pH 4,5, com aplicações de 0; 2 e 4 tone ladas de calcário dolomítico por hectare e por Neptune cita- 
do por NEPTUNE (1975) num Latosol arenoso de pH 4,9 recebendo 2,5 toneladas de calcário por hectare.

SOUTO E DOBEREINER (1969) aplicaram carbonato de cālcio em dois solos, com o objetivo de elevar o pHa 6,5 e eliminar a toxidez de manganès dos mesmos. Estudaram o comportamento de duas variedades de soja perene (Tinaroo e SP-1) e puderam verificar que a calagem proporcionou um aumento da ordem de 10 a 30 vezes no nitrogènio fixado e na produção de forragem. Também observaram que a variedade Tinaroo é muito mais sensível à toxidez de manganēs que a SP-l, sendo principalmente sua simbiose mais afetada pelo excesso desse elemento.

QUAGLIATO e NUTI (1969) realizaram ensaios de vasos com soja perene em dois solos e empregando quatro níveis de calcário $(0,35 ; 0,70 ; 1,40$ e 2,80 t/ha no solo de $\mathrm{Pi}-$ rassununga e $0 ; 0,70 ; 1,40$ e 2,80 t/ha no solo de Nova Odessa). observaram que a produção de matéria seca da leguminosa, em ambos os solos aumentou até a dose de 1,4 toneladas de calcário por hectare, a qual elevou, aproximadamente, o pH do solo de Pirassununga a 5,7 e o de Nova Odessa a 5,2.

As respostas da soja perene a quatro níveis de calagem em dois latosolos ácidos 10 a 2.000 quilos de calcário dolomitico por hectare num Latosol Vermelho Amarelo e 0 a 4.200 quilos por hectare num Latosol Vermelho Escuro), foram estudadas por LOVADINI (1972). Constatou que a aplicação do calcārio provocou acréscimos na produção de matéria seca e na 
absorção de nitrogênio, cālcio, magnésio, potāssio, enxofre e aluminio da leguminosa desenvolvida em ambos os solos.

Cultivando a soja perene Tinaroo num Latosol Vermelho Escuro, FRANÇA et alii (1973) verificaram efeitos po sitivos marcantes da calagem no peso seco das plantas e nos teores de nitrogênio, fósforo, cālcio e magnésio das mesmas. 0 peso dos nódulos foi reduzido pela calagem, em auséncia de boro. A calagem envolveu a aplicação de 6 toneladas de carbonato de cálcio por hectare, a qual elevou o pH do solo de 4,3 para 5,7 .

MUNNS e FOX (1977) trabalharam com um 0xisol do Havaí cultivando dezoito leguminosas(entre as quais esta vam a soja perene Cooper e Tinaroo) sob doses de carbonato de cálcio de 0 a 22 toneladas por hectare, as quais elevaram 0 pH do solo de 4,7 até 7,1 . Para a obtenção de $90 \%$ da produção máxima alcançada de matéria seca a soja perene Cooper necessi tava de 6 toneladas de calcārio por hectare enquanto a Tina roo requeria 5 toneladas por hectare. A magnitude de aumento de produção de matēria seca devido à calagem foi de cinco vezes para a variedade Tinaroo e de trés vezes para a Cooper. A avaliação dos efeitos da calagem na nodulação e fixação de ni trogénio nesse experimento foi realizada por MUNNS et alii (1977). Estes autores observaram que o número de nódulos nas duas variedades de soja perene aumentava com a elevação do $\mathrm{pH}$ a té em torno de 6,0 , enquanto o tamanho dos nōdulos sofria acréscimos devido a calagem até em pH ligeiramente superior a 
6,0 para a soja perene Tinaroo e para a faixa de pH 5,0 a 5,5 para a soja perene Cooper. Na variedade Tinaroo a eficiéncia dos nódulos em fixar nitrogènio acompanhou a tendēncia do número deles e na cooper a fixação de nitrogênio continuou sendo mais eficiente, embora o número de nōdulos diminuĩsse em pH mais elevado. Conclusivamente, afirmam esses autores que o aumento no tamanho dos nōdulos seria o maior responsāvel pelo aumento da produção de matéria seca na variedade Tinaroo, como consequência da aplicação do calcārio.

os efeitos do emprego de trés doses de calcário dolomitico (0; 1,5 e 4,0 toneladas por hectare) num Latosol Vermelho Amarelo com pH 5,0 e o aluminio trocāvel de 1,0 equivalente miligrama por 100 mililitros de solo, cultivado com soja perene, foram estudados por LOVADINI et alii (1977). Realizaram cinco cortes na leguminosa e verificaram que a maior dose de calcārio aplicada resultou em produção de mais matéria seca que as outras duas menores e que estas duas não diferiram entre si, quanto a esse parámetro. Quando compararam os da dos relativos ao conjunto dos cortes realizados, obtiveram $44 \%$ de aumento na produção de matéria seca, $13 \%$ de diminuição na porcentagem de proteína e $8 \%$ de aumento na produção total de proteína, mediante a aplicação de 4 toneladas de calcārio por hectare.

\subsubsection{Estudos com centrosema}

ANDREW e NORRIS (1961) cultivaram nove leguminosas forrageiras em um solo com pH 5,5 e com 0, l equivalen - 
tes miligrama de cálcio trocável por 100 gramas de solo que re presentava $3 \%$ da capacidade de troca total do referido solo, empregando oito níveis de carbonato de cālcio ( 0 a $2.500 \mathrm{~kg} / \mathrm{ha}$ ). Uma das espécies estudadas foi a centrosema que mostrou acréscimos na produção de matéria seca e no nitrogénio total da par te aérea até a dose de 1.250 quilos de carbonato de cálcio por hectare (a qual elevou o pH do solo a 6,4). A avaliação da nodulação efetuada para os tratamentos entre a dose 0 e 750 quilos de carbonato de cálcio por hectare mostrou crescentes nümero e peso de nódulos da centrosema. O teor de cálcio na parte aérea da leguminosa foi crescente do menor até os dois maio res niveis de calagem.

DÖBEREINER e ARONOVICH (1966) estudaram, em cen trosema, o efeito da aplicação do calcário num solo com proble mas reconhecidos de toxidez de manganès. Verificaram aumentos significativos na produção de matēria seca, no nūmero de nōdulos e no nitrogènio total da centrosema, mediante a aplicação do calcário que elevou 0 pH do solo de 4,7 para 5,8. 0 teor de manganès das plantas oriundas de vasos com calcário e dependen tes do nitrogênio fixado biologicamente foi menor que $100 \mathrm{ppm}$, enquanto nos vasos sem calcārio esse teor foi ligeiramente superior a $300 \mathrm{ppm}$.

Cultivando a centrosema em dois solos da Nigéria, nos quais estudaram a calagem na forma de carbonato de cálcio, odU et alii (1971) puderam verificar que os mais altos valores para a produção de matéria seca e para o nūmero de nō- 
dulos bem como as mais eficientes fixações de nitrogênio ocor reram em pH final de 6,1 e 6,4 para cada um dos dois solos.

TEITZEL e BRUCE (1972) realizaram uma série de onze experimentos em vasos com solos originados de basaltos, na Austrália e em um deles cultivaram a centrosema. Esse solo tinha pH 6,0; cālcio trocável de 1,92 miliequivalentes por cento e magnésio trocável de 0,88 miliequivalentes por cento. Verificaram respostas significativas e positivas em termos de produção de matéria seca e porcentagem de nitrogênio na leguminosa, para uma aplicação de 560 quilos de carbonato de cālcio por hectare.

Realizando um ensaio em casa-de-vegetação WERNER e MATTOS (1972) cultivaram a centrosema num Latosol Verme Tho Escuro-orto e testaram, entre outros tratamentos, três ni veis de calagem. O solo original tinha pH 5,30 e aluminio tro cável de 0,70 equivalentes miligrama por 100 mililitros de so 10. A calagem para neutralizar o aluminio trocável além de realmente conseguir essa neutralização elevou o pH do solo a 5,8 enquanto a calagem para pH 6,5 elevou esse indice para 6,1. A produção de matéria seca e o peso de nōdulos decresceram à medida que se aplicou as doses de calcário. Estas, por sua vez, resultaram em aumentos nos teores de nitrogēnio, cál cio, fósforo, molibdénio e cobre nas plantas. Os teores de zinco e de manganès, bem como o nitrogènio total nas plantas sofreram aumentos com a calagem para neutralização do alumí nio trocável, mas voltaram a decrescer com a mais alta dose 
de calagem.

SOARES e VARGAS (1974) estudaram o efeito da ca lagem na centrosema cultivada em três latosolos coletados na região de cerrado. Esses solos tinham pH e aluminnio trocável (equivalentes miligrama por 100 gramas de solo) de 5,2 e 0,9; 5,2 e 0,7 e 4,2 e 2,0 e receberam calagem à base de 1,$8 ; 2,8$ e 6,0 toneladas de calcário, respectivamente. Verificaram, em todos os solos que a aplicação de calcārio resultou em efeitos significativos e benéficos na produção de matéria seca da par te aérea, no sistema radicular e no teor de proteína da leguminosa.

\subsubsection{Estudos com siratro}

FREITAS E PRATT (1969) conduziram experimentos em casa-de-vegetação, com oito solos do Estado de São Paulo (quatro latosolos e quatro podzólicos), testando o efeito de níveis de calcário em três leguminosas forrageiras, entre as quais estava o siratro. Os solos estudados tinham pH, por oca sião da semeadura, no tratamento sem calcário, variando entre 4,4 e 4,7. Puderam verificar um aumento médio de produção de matéria seca de 93\% no siratro, pela adição do calcário, elevando o pH do solo de 4,5 para 6,0. A maior produção dessa le guminosa ocorreu em pH 6,1 e ligeiro decréscimo de produção foi notado quando o pH ascendeu a mais que 6,2. Acrescentam, também, que o siratro parece ser altamente sensivel à toxidez de manganēs.

Os efeitos da aplicação de duas doses de calcá- 
rio num Latosol Vermelho Amarelo - fase arenosa, cultivado com siratro, foram estudados por BRAZON (1971). O solo tinha um pH inicial de 5,0 e o aluminio trocável de 0,8 equivalen tes miligrama por 100 gramas de solo. Concluiu o autor que a calagem não teve efeito sobre a produção de matéria seca da parte aérea e dos nōdulos; teve efeito depressivo sobre a pro dução de matéria seca das raízes; incrementou o conteūdo de nitrogênio na parte aérea e nos nódulos; não resultou em alte ração no conteüdo de nitrogēnio nas raízes e proporcionou aumento no teor de magnésio na parte aérea da leguminosa.

$$
\text { Em ensaio de casa-de-vegetação, MATTOS }
$$

trabalhou com o siratro num Latosol Vermelho Escuro-orto que tinha pH 5,5 e aluminio trocável de 0,8 equivalentes miligrama por 100 gramas de solo. Aplicou cinco doses de calcārio (0; $1 ; 2 ; 3$ e 4 toneladas por hectare) e obteve efeitos significa tivos nos aumentos de produção de matéria seca da parte aérea e das raízes, na quantidade de nitrogênio extraîdo, no nümero de nōdulos e na massa nodular até a dose de 2 toneladas de calcārio por hectare. 0 emprego do calcārio resultou em incre mentos positivos nos teores de câlcio e de magnésio na parte aérea, contribuiu para deprimir os teores de boro, manganés e zinco da parte aérea mas não alterou os teores de nitrogènio da leguminosa.

KOLLING et alii (1974) empregaram um U1tisol

ácido $\left(\mathrm{pH}=5,3\right.$ e $\mathrm{Al}{ }^{+++}$trocāvel $\left.=1,00 \mathrm{mE} / 100 \mathrm{~g}\right)$ para, entre ou tros, estudar o efeito da calagem em siratro. o calcārio foi 
utilizado nas doses de $0 ; 1,1 ; 2,2 ; 3,3$ e 4,4 toneladas por hectare, o que proporcionou valores de pH do solo, após incubação, de 5,$0 ; 5,1 ; 5,7 ; 5,8$ e 6,4 , respectivamente. Constata ram que o calcário proporcionou aumento significativo na produção de matéria seca do siratro e as maiores produções estiveram nas doses 1,1 e 2,2 toneladas por hectare. A nodulação da leguminosa não foi afetada pelo calcārio e os teores de ni trogênio não mostraram clara tendéncia de variação em função da calagem.

Trabalhando com um Latosol Vermelho Escuro Eutrōfico, GAVAZONI et alii (1979) aplicaram 0 e 1,5 toneladas de calcário calcitico por hectare, para o cultivo de siratro em canteiros experimentais. 0 solo tinha um pH inicial de 5,6 e o alumínio trocável de 0,5 equivalentes miligrama por 100 mililitros de solo. Juntamente com o calcário distribuíram = 375 quilos de sulfato de magnésio por hectare. Com base nos dados coletados em cinco cortes nas parcelas do ensaio, concluiram que o calcário não proporcionou efeitos significati vos na produção de matēria seca da leguminosa, mas que o efe to do adubo fosfatado na porcentagem de proteina bruta somente ocorreu na presença do corretivo. Acrescentaram ainda que a aplicação da calagem resultou em aumento no teor de magné sio, em redução no teor de zinco e não alterou significativamente os teores de cālcio, cobre e manganés na leguminosa.

2.1.3.4. Estudos com galactia

MATTOS e ALCÂNTARA (1976) descrevem que a pri- 
meira coleta e introdução dessa leguminosa foi realizada em 1963 e que mais tarde se iniciaram os estudos a respeito dela em Nova Odessa, SP. Embora descrevam uma sērie de características favorāveis da galactia para uso na alimentação animal, os estudos sobre a nutrição mineral dessa espēcie são ainda muito escassos. Com relação à este aspecto, os referidos auto res mencionam que a galactia tolera os solos de baixo pH e se desenvolve bem mesmo em solos de baixa fertilidade.

MATTOS e WERNER (1972) realizaram ensaio de vasos com a galactia num solo Podzōlico Vermelho Amarelo - va riação Laras com pH iniciāl de 5,8. Verificaram que a omissão de calagem não resultou em redução significativa na produção de matéria seca da leguminosa.

Em trabalho com uma Areia Quartzosa coletada no cerrado de Brotas $\left(\mathrm{pH}=4,8\right.$ e $A 1^{+++}$trocável=0,8 equivalentes miligrama por 100 mililitros de solo), MONTEIRO et alii (dados não publicados) verificaram que a calagem foi um dos três fatores mais limitantes a um a dequado desenvolvimento da galactia nesse solo.

\subsubsection{Estudos com mais de uma leguminosa}

Duas variedades de soja perene (Comum e Tinaroo), centrosema e siratro foram cultivadas por FRANל̧A e CARVALHO (1970) num solo de cerrado com pH=4,3, cálcio trocável baixo, traços de magnésio trocável e alumínio trocāvel de 0,62 equivalentes miligrama por 100 gramas de solo. Aplicaram calcārio que elevou o pH a 6,0 e constataram que a produção 
de matéria seca e o nitrogènio total nas plantas foram esta. tísticamente superiores na presença do calcārio. Mediante o emprego do calcário, o peso de nōdulos somente foi alterado na centrosema onde o corretivo teve efeito negativo.

As respostas de soja perene, siratro e centrosema à sete níveis de calagem em um latosolo de cerrado, foram estudadas por JOṆES e FREITAS (1970). As adições de calcāa rio fizeram variar o pH do solo na fase inicial do cultivodas plantas, de 4,5 a 6,8 . Verificaram que a soja perene foi a es pécie menos produtiva em ausência de calagem e que a produção das três leguminosas aumentaram até o quinto nīvel de calagem (pH de 6,4 no inicio do experimento). As doses subsequentes determinaram decréscimos na produção de matēria seca das legu minosas. Observaram tambēm, elevações nos teores de proteina, de cālcio e de magnésio e redução na porcentagem de potās sio, mediante a aplicação do calcārio.

JONES et alii (1970) éstudaram as respostas à aplicação de calcārio a um solo Latosol Vermelho cultivado com oito leguminosas forrageiras, entre as quais estavam a centro sema e a soja perene. A calagem, que elevou o pH do solo de 4,7 a 7,6 , resultou em aumentos significativos na produção de matéria seca e no nitrogênio total bem como em redução nos teores de boro, zinco, manganés e ferro das duas leguminosas citadas.

Os efeitos da aplicação de uma calagem que elę you o pH de um Latosol Vermelho Escuro de 4,7 para 5,8, em so 
ja perene comum, soja perene Tinaroo, centrosema e siratro, foram estudados por CARVALHo et a 1 i i (1971). Em termos de pro dução de matéria seca, a calagem somente teve influéncia para a soja perene comum, na qual foi benéfica. o nitrogènio total nas plantas, embora estivesse na faixa de 60 a $70 \%$ dos valores obtidos na presença de calagem para as duas variedades de soja perene e para a centrosema, não mostrou variação signifi cativa em decorrência do emprego da calagem. Também, a calagem não teve efeito significativo sobre o nümero e peso de nô dulos dessas quatro leguminosas.

o cultivo da soja perene Tinaroo e do siratro

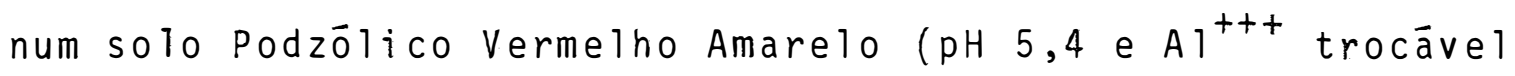
de 0,1 equivalentes miligrama por 100 mililitros de solo) foi efetuado por EIRA et alii (1972). Adicionaram o calcārio para elevar o pH a 6,5 e verificaram, nessa condição de menor acidez, significativos aumentos no nitrogénio total da soja pere ne e na porcentagem de nitrogénio do siratro, bem como significativo decréscimo no peso das raízes do siratro. Em termos de produção de matēria seca e de nūmero e peso de nōdulos não constataram efeito da calagem, em qualquer das leguminosas.

KORNELIUS e STAMMEL (1973) realizaram ensaio de vasos, com um Molisol de pH inicial 5,5, trabalhando com soja perene Cooper e siratro. Empregaram o calcārio nas doses de $0 ; 1,2$ e 2,4 toneladas por hectare e concluíram que a produção total de matéria seca da soja perene sofreu aumentos significativos com a calagem, enquanto para o siratro esses 
efeitos foram negativos. Observaram as maiores produções de matéria seca em pH final de 5,4 para o siratro e de 5,9 para a soja perene.

Um Ultisol ácido da Costa Rica foi utilizado por TRIGOSO e FASSBENDER (1973) para cultivo de soja perene, centrosema e siratro. Em termos de calagem, verificaram sua influência positiva na produção de matéria seca, na massa nodular, na quantidade de nitrogènio fixado e no nitrogènio absorvido pelas leguminosas estudadas.

Trabalhando com um Latosol Vermelho Escuro - fa se cerrado, CARVALHO et alii (1974) aplicaram 4.300 quilos de calcário dolomítico ou 3.100 quilos de calcário calcítico para o cultivo da soja perene e do siratro. Tendo analisado os dados relativos a quatro cortes, constataram que o corretivo do solo teve efeito positivo sobre a produção de matéria seca e de proteina, a partir do segundo corte, para as duas legumi nosas. Acrescentaram, também, que não houve diferenças entre as duas fontes de calcário testadas.

MIRANDA (1979) trabalhou com um solo Podzólico Vermelho Amarelo (pH 5,7 e Al ${ }^{+++}$trocāvel $=0,08$ equivalentes miligrama por 100 gramas de solo) e uma Areia Quartzosa Distrōfica $\left(\mathrm{pH} 5,0\right.$ e $\mathrm{Al}^{+++}$trocável $=1,04$ equivalentes miligrama por 100 gramas de solo), nas quais cultivou soja perene co mum, siratro e galactia. A calagem na forma de carbonato de cálcio compreendeu a aplicação de 2,0 toneladas por hectare na Areia Quartzosa e 1,5 toneladas por hectare no solo Podzó- 
lico. A aplicação de cālcio e de magnésio como nutrientes tam bém constou da série de tratamentos. No solo Podzólico, a ausência somente de calagem não resultou em variação significativa da produção de matéria seca nas très espécies, enquanto a omissão conjunta de calagem e de cālcio resultou em redução significativa naquela variāvel para as trés leguminosas. Na Areia Quartzosa a omissão exclusiva da calagem resultou em acréscimos na produção de matéria seca do siratro e da galactia. Nesse mesmo solo o tratamento "menos calagem e cálcio" concorreu para díminuir a produção de matéria seca da soja pe rene e para aumentar a da galactia. A calagem resultou em aumento no teor de cālcio e em diminuição nos teores de boro, ferro, manganès e zinco nas três espécies desenvolvidas nos dois solos.

\subsection{Micronutrientes}

De acordo com FRANCO (1978) a deficiência de micronutrientes pode se constituir num sério problema de fertilidade nos solos tropicais altamente lixiviados e com baixo pH. Afirma que, nessas condições alguns elementos (por exem plo, boro e zinco) podem ser deficientes devido à lavagem do solo, enquanto outros (por exemplo, molibdênio) podem estar indisponíveis às plantas devido a adsorção às partículas do solo. Por outro lado o uso de calagem para esses solos ácidos influi diretamente na disponibilidade dos micronutrientes para as plantas. WERNER (1975) revisando a literatura sobre o uso de micronutrientes em pastagens concluiu que seria neces- 
sārio apenas o acrēscimo de molibdēnio na adubação, quando se adota o critério da aplicação de calagens baixas a moderadas. Entretanto, quando se usam doses mais elevadas de corretivos da acidez, seria mais importante o fornecimento de outros micronutrientes cuja disponibilidade diminui com a elevação do pH.

Esta revisão é dirigida diretamente a quatro micronutrientes dentre os sete que jā tem reconhecida sua essencialidade para o normal desenvolvimento das plantas. Serão aqui tratados: boro, cobre, molibdēnio e zinco.

\subsubsection{Micronutrientes para leguminosas}

2.2 .1 .1$. Boro

ANDREW (1962) menciona que o boro é essencial para o desenvolvimento das raĩzes e tambēm para a formação dos nōdulos nas leguminosas. De acordo com MALAVOLTA (1976) a menor nodulação em leguminosa deficiente em boro seria o resultado da dificuldade de translocação de carboidrato na plan ta, quer pela não formação de complexos àcido bōrico - carboi dratos, quer pela desorganização nos vasos condutores.

Sob condições de caréncia de boro, quando os nōdulos se desenvolvem, eles são pequenos e possuem falhas no seu sistema vascular e nos bacteróides (FRANCO, 1978).

Borshchenko e Sherstnew citados por PRICE et alij (1972) relatam decréscimo na sĩntese de proteĩna em raízes de leguminosa deficiente em boro. 


\subsubsection{Cobre}

HALLSWORTH (1958) descreve um efeito definido do cobre na fixação de nitrogênio através de uma adequada for mação de nódulos, quando se acrescenta cobre à solução nutridora da leguminosa.

Jà CARTWRIGHT e HALLSWORTH (1970) referem-se à necessidade de cobre para o desenvolvimento das bactérias do gênero Rhizobium, bem como para a atividade dos nódulos.

PRICE et alii (1972) relacionam vārias proteínas contendo cobre, entre elas estando a oxidase de diamino e a proteina azul, originadas em leguminosas.

MALAVOLTA (1976) menciona que plantas carentes de cobre mostram menor sintese proteica.

De acordo com FRANCO (1978) as leguminosas deficientes em cobre tem nódulos menores e menor número de bacteróides nos nódulos que as bem supridas com esse elemento.

\subsubsection{Molibdènio}

HALLSWORTH (1958) afirma ser muito claro o papel do molibdēnio na eficiência da fixação e não na nodulação da leguminosa. Conforme ANDREW (1962) o requerimento de molibdēnio pelo Rhizobium é maior que o da planta hospedeira e que esse micronutriente é essencial em duas fases da nutrição da leguminosa: no eficiente funcionamento do Rhizobium e no metabolismo do nitrogênio nas plantas. A influência do molibdênio nessas duas fases està relacionada à duas enzimas, a ni 
trogenase e a redutase do nitrato, respectivamente (PRICE et alii, 1972 e EPSTEIN, 1975). Na nitrogenase a função do molib dēnio seria o enfraquecimento da ligação entre os dois àtomors de nitrogēnio, o que os tornaria suscetiveis de redução (EPSTEIN, 1975 ).

\section{2 .1 .4$. Zinco}

Mulder, citado por HEWITT (1958) verificou que com a deficiēncia de zinco houve formação de nōdulos pequenos, a capacidade de fixação de nitrogênio foi alterada e o cresci mento da leguminosa foi deprimido. Essa interferéncia no cres cimento da planta pode ser atribuída a uma deficiēncia de āci do indolacético, como consequẽncia da falta de triptofano na planta, o qual por sua vez tem sua sintese diminuida em planta carente de zinco (MALAVOLTA, 1976).

FRANCO (1978) ao analisar o papel dos micronutrientes no sistema leguminosa - Rhizobium, afirma que a deficiēncia de zinco, primariamente limita o crescimento da planta hospedeira.

2.2.2. Respostas das leguminosas forrageiras tropicais à aplicação de micronutrientes no solo.

$\bar{A}$ semelhança do procedimento adotado ao se ana lisar a calagem, tratar-se-ā aqui somente dos resultados expe rimentais obtidos com soja perene, centrosema, siratro e galactia. 


\subsubsection{Estudos com soja perene}

Quagliato e Jones, citados por QUAGLIATO (1966), cultivaram a soja perene em solo de Nova Odessa, com pH inicial de 4,5. Em presença de calagem e como média de três cortes, verificaram reduções na produção de matéria seca da legu minosa, da ordem de $23 \%$ para a omissão de boro e de $6 \%$ na ausência de cobre ou molibdénio no tratamento completo. A omissão de zinco não proporcionou variação na produção da planta.

Trabalhando com solos de Pirassununga e de Nova Odessa, QUAGLiato e NUTI (1969) testaram a aplicação, respectivamente, de boro + zinco e de boro + molibdènio, em presença de níveis de calagem. Verificaram, para o Regosol de Pí rassununga que as maiores produções de matēria seca e nūmero de nōdulos na soja perene ocorreram com a aplicação de 1,4 to neladas de calcārio por hectare (pH em terno de 5,7) e na presença dos dois micronutrientes. No solo de Nova Odessa, a presença de boro e molibdénio se fez sentir no aumento da pró dução de matēria seca, especialmente quando se passou de $\mathrm{pH}$ 5,2-5,3 para 5,7-5,9. Sem esses dois micronutrientes, essa elevação do pH pela calagem não resultou em maior produção da leguminosa, enquanto sensível aumento nessa variāvel foi cons tatado em presença de boro e molibdēnio juntos.

os efeitos de boro, molibdēnio e zinco em soja perene Tinaroo cultivada num Latosol Vermelho Escuro - fase cerrado, foram estudados por FRANÇA et alii (1973). Esses micronutrientes foram empregados em solo sem calagem $(\mathrm{pH}=4,3)$ e 
com calagem $(p H=5,7)$. Em pH mais baixo, a adição de molibdénio resultou em sensiveis aumentos na porcentagem de nitrogê nio total na planta. Em pH mais elevado, foram boro e zinco que proporcionaram os acréscimos na produção de matéria seca, no nitrogénio total e no peso dos nödulos. A aplicação do bo ro, em presença da calagem, reduziu o teor de nitrogénio na planta. 0 molibdēnio em presença da calagem e o boro e zinco em ausēncia de calagem, não mostraram efeitos significativos nas variāveis citadas, o que bem ilustra a mudança na disponibilidade desses micronutrientes em função do pH do meio, conforme proposto por LINDSAY (1972) e ASHER (1979).

WERNER e MATTOS (1974) cultivaram a soja pere ne comum em um Latosol Vermelho Escuro-orto, testando os micronutrientes boro, cobre, molibdēnio e zinco, num pH final de 6,0. Verificaram que o molibdēnio foi o que apresentou os efeitos mais marcantes, tendo influenciado significativamente em aumentos da produção de matēria seca, da porcentagem de nitrogēnio, do nitrogénio total e da massa nodular da leguminosa. A aplicação de boro resultou em aumentos significa tivos na produção de matéria seca e no nümero e peso de nōdu los, mostrando porēm tendēncia em reduzir o teor de nitrogénio na planta. o cobre provocou aumentos significativos no peso de nōdulos e mostrou interação positiva com o molibdé nio no aumento da porcentagem de nitrogénio nas raízes. 0 emprego do zinco não influenciou significativamente em qualquer das variāveis abordadas. Relatam ainda que a aplicação 
conjunta dos quatro micronutrientes resultou em efeitos negativos e significativos para a produção de matéria seca, teores de nitrogénio e para o nitrogēnio total das raízes da planta.

\subsubsection{Estudos com centrosema.}

\section{ANDREW e THORNE (1962) testaram as respostas}

de leguminosas temperadas e tropicais (entre as quais estava a centrosema) ao emprego de niveis de cobre. A aplicação de seis niveis de cobre (0 a 8 quilos de sulfato de cobre por hectare) a um solo com pH inicial de 5,5 e recebendo 625 quilos de carbonato de cālcio por hectare, resultou em expressivos aumentos na produção de matéria seca e no teor desse micronutriente na parte aērea da centrosema. 0 tratamento que não recebeu cobre mostrou uma produção de matéria seca de $45 \%$ da māxima alcançada no ensaio. Em outro experimento, com solu ção nutritiva, tambēm ocorreram expressivas elevações na produção de matēria seca e na concentração de cobre na parte aérea da planta. Nesse segundo ensaio, as plantas crescidas na solução que não recebeu cobre, tiveram produção de $17 \%$ da máxima alcançada.

Trabalhando com solos de origem basāltica do Queensland (Austrälia), TEITZEL e BRUCE (1972) realizaram uma sērie de experimentos com leguminosas forrageiras, nos quais testaram a deficiēncia geral de nutrientes. Em um dos experimentos, cultivaram a centrosema em solo com $p H=6,0$ e verifica ram que o molibdênio contribuiu para aumentos na produção de 
matēria seca e no teor de nitrogénio da planta, quer em presença ou em auséncia de calagem. Acrescentam ainda que em amostragens realizadas em pastagens cultivadas próximo aos seus experimentos, puderam constatar aumento de $27 \%$ na porcentagem de nitrogēnio da centrosema, bem como maior lotação da pastagem, devidos ao acréscimo do molibdénio ao superfosfa to na adubação da pastagem consorciada.

A adição de boro, cobre, molibdēnio e zinco jun tos a uma adubação completa para centrosema cuitivada num Latosol Vermelho Escuro-orto, foi estudada por WERNER e MATTOS (1972). O pH do solo estava em torno de 5,8 a 5,9. Verifica ram que a adição conjunta dos quatro micronutrientes resultou em decréscimos na produção de matēria seca, no nūmero e peso de nōdulos, no nitrogēnio total da planta, bem como nos teores de cobre e zinco na leguminosa. Posteriormente, WERNER e MATTOS (1975) trabalharam com a centrosema cultivada em solo coletado no mesmo local que o ensaio anterior, testando os quatro micronutrientes num esquema fatorial. $0 \mathrm{pH}$ do solo ao final do ensaio estava em 6,03 e puderam constatar que o molib. dénio provocou aumentos significativos na porcentagem de nitrogēnio e no nitrogénio total na planta. o boro produziu aumento significativo no nümero de nōdulos enquanto o cobre e o zinco isoladamente não provocaram efeitos significativos nas variāveis estudadas. 0 cobre e o molibdēnio mostraram interação significativa e positiva na produção de matēria seca e de nitrogēnio total na leguminosa,ao passo que as interações trí 
plice de boro, cobre e zinco ou a quádrupla (boro, cobre, molibdénio e zincol foram significativas e negativas para o nitrogênio total na centrosema. Ainda, aquela interação trîplice foi prejudicial à concentração de nitrogênio na planta.

0 emprego conjunto de molibdènio e cobre em parcelas consorciadas de centrosema com capim gordura, no mes mo local de onde foi retirado o solo para os ensaios de vasos de WERNER e MATTOS (1972) e WERNER e MATTOS (1975) é relatado por WERNER (1975). Estando o solo com um pH=5,3, o autor mostra aumentos da ordem de $86 ; 108$ e $139 \%$ na produção de matēria seca da centrosema, nos três primeiros cortes do experimento, mediante a aplicação dos micronutrientes, Tambēm, por ocasião do terceiro corte a centrosema tinha sua porcentagem sobre a produção total da parcela, mais que duplicada, quando em presença desses dois elementos.

SOARES e VARGAS (1974) cultivaram a centrosema em três latosolos, em presença de calagem, e verificaram que o boro induziu significativos aumentos na produção de matéria seca e de proteina dessa leguminosa no Latosol Vermelho Escuro. A adição conjunta de quatro micronutrientes (cobre, manga nès, molibdénio e zinco) teve efeito benéfico na produção de matēria seca e na eficiēncia de fixação de nitrogēnio e os autores atribuem esses benefícios à adição de molibdénio.

Os efeitos da aplicação de quatro micronutrien tes num esquema fatorial, a um solo Podzolizado de Lins e Ma rilia coletado em Andradina, SP e cultivado com a centrosema, 
foram estudados por MONTEIRO et ali i (1975). Verificaram efe $\underline{i}$ tos significativos desses elementos somente no segundo corte do experimento, quando o molibdènio influenciou em aumentos na porcentagem de nitrogênio e no nitrogēnio total na planta. o cobre resultou em variação positiva no teor de nitrogênio na leguminosa, enquanto o boro e o zinco não mostraram efeitos nas variāveis abordadas.

Em outro solo Podzolizado de Lins e Marilia, coletado em São José do Rio Preto, SP, WERNER et alii (1975 b) realizaram um ensaio fatorial com boro, cobre, molibdēnio e zinco em centrosema. Puderam constatar os efeitos desses nutrientes no segundo corte do experimento, verificando influen cia significativas e positivas do molibdênio na porcentagem de nitrogènio e do molibdēnio e do zinco no nitrogènio total na leguminosa. Efeitos significativos e negativos no teor de nitrogènio na centrosema foram obtidos com o emprego do boro. DE-POLLI et alii (1976) realizaram a aplicação de micronutrientes num solo Podzölico Vermelho Amarelo com pH 5,5 e cultivado com centrosema. Puderam constatar que o moli $\underline{b}$ dênio influenciou aumentos significativos na produção de maté ria seca, na porcentagem de nitrogènio e no nitrogènio total na planta, mas resultou em decréscimo significativo no número e peso de nōdulos totais na leguminosa. O zinco favoreceu aumentos na produção de matéria seca e no nitrogēnio total, enquanto o boro proporcionou elevação significativa no nitrogênio total da centrosema. A aplicação de cobre não resultou em 
variação significativa quer no crescimento, quer na nodulação da centrosema.

A aplicação de micronutrientes na forma de FTE-Br 15 (contém somente boro, cobre, molibdēnio e zinco) em um solo Podzólico Vermelho Amarelo destinado a desenvolvimen to da centrosema, foi efetuada por NERY et alii (1976). Com aplicação normal da formulação, no solo (40kg/ha) os efeitos foram muito insignificantes na centrosema, enquanto pesada adubação (200kg FTE-Br $15 / \mathrm{ha}$ ) provocou aumentos em torno de $25 \%$ na produção de matēria seca, no nümero e peso de nōdulos totais e de cerca de 10\% no nitrogénio total dessa leguminosa.

\subsubsection{Estudos com siratro.}

TRUONG et alii (1967) cultivaram o siratro num solo arenoso de $\mathrm{pH}=6,2$, no qual testaram os efeitos da presen ça ou não de boro, de cobre, de molibdēnio e de zinco, isoladamente. Puderam verificar que a auséncia de molibdênio ou a presença de zinco resultou em decréscimo significativo na pro dução de matéria seca dessa leguminosa.

TEITZEL (1969) realizou experimento de campo na região costeira de Queensland (Austrāila), efetuando entre outras, a aplicação de cobre em parcelas de siratro. Pode o autor verificar uma clara resposta (em produção de matéria se ca) do siratro à cobre, na presença de adubo fosfatado. Nenhum outro nutriente por si, teve efeito no crescimento da planta, mas quando cobre era aplicado, havia uma resposta adi cional ao potássio. o emprego de cobre aumentou ligeiramente 
a porcentagem de nitrogēnio e sensivelmente o nitrogênio total na leguminosa.

Dentro de uma série de experimentos com solos australianos de origem granitica, TEITZEL e BRUCE (1971) tes taram o siratro em dois desses solos. Verificaram que depois do fósforo, o cobre era o elemento mais limitante para a produção dessa leguminosa.

Trabalhando com siratro num Latosol Vermelho Escuro-orto, MATTOS (1972) testou a aplicação de molibdēnio e a conjunta de boro, cobre e zinco, em presença de cinco níveis de calagem. Constatou que o molibdênio teve efeitos bené ficos na produção de matēria seca e no nūmero e peso de nōdulos, mas foi prejudicial à absorção de cobre pela planta. A utilização de boro, cobre e zinco em conjunto proporcionou in crementos no desenvolvimento da raiz, no nümero e peso de nōdulos e nos teores de boro e zinco na planta. O efeito desses trés micronutrientes se fez sentir no crescimento da raiz, es pecialmente com a elevação da cal agem. 0 emprego dos quatro micronutrientes juntos resultou em decréscimos na produção de matēria seca (parte aērea e raiz) mas incrementou o nümero e o peso de nōdulos do siratro.

TEITZEL e BRUCE (1973) realizaram outra sērie de experimentos com solos australianos derivados de areia de praia, entre os quais cultivaram o siratro em dois ensaios. Puderam constatar efeitos significativos tanto para o boro, como para o cobre e para o molibdênio, na produção de matēria 
seca dessa leguminosa.

\subsubsection{Estudos com galactia}

MATTOS e WERNER (1972) estudaram os efeitos da aplicação de boro e molibdēnio em um solo Podzōlico Vermelho A marelo - variação Laras, no qual cultivaram a galactia. o molibdēnio não provocou variação na produção de matéria seca da leguminosa, enquanto na ausēncia de boro essa variável tendeu a aumentá-la, fazendo com que os autores levantassem a suspe ta de possivel toxidez de boro na galactia.

Em trabalho relatado em EMPRESA BRASILEIRA DE PESQUISA AGROPECUARIA (1979) e conduzido num Latosol Roxo de cerrado, com galactia, constatou-se que a omissão de boro resultou em sensĩveis decréscimos da produção de matēria seca, do nümero e do peso de nódulos dessa leguminosa.

MONTEIRO et alii (dados não publicados) trabaTharam com uma Areia Quartzosa coletada no cerrado de Brotas, SP e constataram que o molibdēnio foi um dos trés fatores nutricionais mais limitantes ao desenvolvimento da galactia.

\subsubsection{Estudos com mais de uma leguminosa}

Trabalhando com um Latosol Vermelho de cerrado, em presença de calagem $(p H=6,0)$, FRANÇA e CARVALHO (1970) aplicaram os micronutrientes em conjunto para o cultivo da soja perene comum, soja perene Tinaroo, centrosema e siratro. Constataram que a presença conjunta de boro, cobre, ferro, mo libdēnio e zinco aumentaram sensivelmente a produção de maté- 
ria seca, o peso de nōdulos e o nitrogēnio total nas quatro le guminosas mencionadas. Jā, CARVALHO et alii (1971), estudando a aplicação dos mesmos micronutrientes num Latosol Vermelho Es curo-fase mata, de cerrado, cultivado com as quatro legumino sas citadas, não verificaram qualquer efeito desses nutrientes nas variāveis estudadas. Tambēm, nesse solo o emprego dos micronutrientes ocorreu em tratamento com calagem (pH final de $5,8)$.

A omissão de boro, cobre, ferro, molibdēnio e zinco em conjunto resultou em decréscimos significativos na produção de matéria seca e de nitrogênio total e em acrēscimos no teor de nitrogénio na soja perene e na centrosema cultiva das por JONES et alii (1970), num Latosol Vermelho de cerrado (em presença de calagem que elevou o pH a 7,6 ). Esses mesmos autores constataram que a soja perene teve sua produção significativamente diminuida na ausência de zinco num Latosol Verme Tho Amarelo (pH final de 6,3) e na auséncia de boro ou de zinco num Regosol (pH final de 6,1). Todavia, a presença de cobre deprimiu significativamente a produção de matēria seca da soja perene, da centrosema e do siratro cultivadas no Regosol. A so ja perene não teve seu desenvolvimento alterado pela omissão individual de boro, cobre, molibdēnio ou zinco aplicados num Latosol Vermelho de cerrado ( $p H$ final de 6,0).

TRUONG et alii (1971) aplicaram três níveis de molibdēnio $(0,25 ; 0,50$ e 3,00 ppm) em uma solução nutritiva contendo excesso de manganès, onde cresciam soja perene, cen- 
trosema e siratro. Verificaram que a produção de matēria seca dessas trēs leguminosas não variaram significativamente com as doses adicionadas do micronutriente.

A soja perene e o siratro foram cultivados por EIRA et alii (1972) num solo Podzólico Vermelho Amarelo, onde testaram o emprego de boro, cobre, ferro, molibdénio e zinco em conjunto, em presença de calagem para elevar o pH a 6,5 . Constataram que a aplicação desses micronutrientes contribuiu para aumentós expressivos na produção de matéria seca, de nitrogénio total e no peso e tamanho dos nódulos dessas leguminosas.

TRIGOSO e FASSBENDER (1973) aplicaram cinco ni veis de boro e cinco de molibdēnio em soja perene, centrosema e siratro cultivados num Ultisol da Costa Rica, Verificaram que o boro e o molibdēnio não tiveram efeitos significativos na produção de matéria seca e na massa nodular das três leguminosas. Todavia, para a soja perene o molibdénio mostrou efeito positivo no nitrogénio fixado nos nódulos e no nitrogénio total na planta. Para soja perene e siratro, a presença de boro teve efeito benéfico no nitrogēnio fixado nos nōdulos, especialmente para a mais alta dose empregada $(1,2 \mathrm{ppm}$ de boro).

Andrew, citado por FRANCO (1978), mostra o efeito positivo da aplicação de zinco na nodulação de soja perene e siratro cultivados em solução nutritiva.

MIRANDA (1979) testou, entre outros tratamen - 
tos, a omissão conjunta dos micronutrientes boro, cobre, fer ro, manganês, molibdênio e zinco em dois solos (Podzólico Ver melho Amarelo e Areia Quartzosa Distrófica), em presença de calagem ( $\mathrm{pH}$ de 6,3 e 5,9, respectivamente). No solo Podzōlico, verificou significativas diminuições na produção de matéria seca e nos teores de boro, cobre e zinco na soja perene e na galactia, mediante a omissão dos micronutrientes. Nesse mesmo solo a auséncia dos micronutrientes resultou em decréscimo nos teores de boro e zinco do siratro. No solo Areia Quartzosa a omissão dos micronutrientes proporcionou decréscimos na produ ção de matéria seca e nos teores de boro das trés espécies; diminuição nos teores de cobre da galactia e do siratro e no teor de zinco da soja perene. 
3. MATERIAL E METODOS

3. 1. Local

0 experimento foi conduzido em vasos, em casade-vegetação localizada na Estação Experimental Central do Instituto de Zootecnia, em Nova Odessa, Estado de São Paulo.

3.2. Espēcies

Foram estudadas quatro espēcies de leguminosas forrageiras tropicais, a saber:

- Glycine wightii (R. Grah. ex Wight \& Arn.) Verdc. var. Tinaroo - soja perene Tinaroo

- Centrosema pubescens Benth. - centrosema

- Macroptilium atropurpureum D.C. cV. Siratro siratro. 
- Galactia striata (Jacq.) Urb. - galactia.

\subsection{Solo}

o solo envolvido no experimento é classificado como Podzólico Vermelho Amarelo - variação Laras, Alico*. Foi coletado a uma profundidade de $0-30$ centímetros, secado à som bra e passado em peneira com abertura de 3 milimetros.

Uma amostra do solo preparado foi analisada qui micamente e os resultados revelaram: matéria orgānica $=2,1 \%$, $\mathrm{pH}=4,8 ; \mathrm{Al}^{+++}=0,8 ; \mathrm{H}^{+}=2,95 ; \mathrm{Ca}^{++}=0,3 ; \mathrm{Mg}^{++}=0,1 ;$ $\mathrm{K}^{+}=0,07 \mathrm{e}^{---}=0,02$ equivalentes miligrama por cem mililitros de terra fina seca ao ar.

\subsection{Preparação dos vasos e calagem}

Empregou-se vasos de cerâmica com as paredes in ternas pintadas com tinta impermeabilizante e revestidos internamente com sacos plásticos. Em cada vaso colocou-se cinco quilos de terra.

A calagem foi efetuada em 06.02.75. A dose mais elevada de calcário foi determinada por incubação do solo com os óxidos de cālcio e de magnésio, em proporção semelhante a do calcário dolomitico a ser utilizado e teve por meta elevar o pH a 6,5. O ponto de partida para calagem foi o nivel zero de calcário. Como a calagem para neutralizar o aluminio trocá

* Comunicação pessoal do Engọ Agrọ J.B. Oliveira - Seção de Pedologia - Instituto Agronômico - Campinas, SP. 
vel $\left(1,5 \times 0,8\right.$ e.mg $\left.A 1^{+++}\right)$e para elevar o cälcio e o magnésio a 2,0 (2,0 - 0,3 e.mg $\left.\mathrm{Ca}^{++}-0,1 \mathrm{e} \cdot \mathrm{mg} \mathrm{Mg}^{++}\right)$resultariam em niveis que estavam dentro dos valores mínimo e máximo definidos para calagem, optou-se por espaçar igualmente as doses de calcārio.

Dessa forma, o calcārio dolomîtico aplicado nos vasos obedeceu às doses de $0 ; 0,83 ; 1,66$ e 2,49 toneladas do corretivo por hectare, o que correspondeu à $0 ; 1,66$; 3,32 e 4,98 gramas do material por vaso.

o calcārio utilizado procedia de Votorantin-sP, e sua análise química revelou conteūdo de $29,09 \%$ de CaO, de $11,84 \%$ de $\mathrm{MgO}$ e de $17,90 \%$ de sîlica e materiais insolūveis.

Após a mistura de calcārio dolomitico, aplicouse àgua destilada e deionizada até prōximo a capacidade de campo do solo e deixou-se reagindo em repouso até o plantio.

3.5. Plantio, adubação, irrigação e desbastes.

Em 19.03.75 procedeu-se ao plantio das forrageiras nos vasos, em sulcos com 1 a 2 centimetros de profundidade e colocando-se 40 sementes de soja perene var. Tinaroo, 30 de centrosema, 50 de siratro e 25 de galactia, nos vasos respectivos. As sementes da soja perene e do siratro, por apresentarem relativamente baixa porcentagem de germinação, foram escarificadas mecanicamente, antes da semeadura.

os nutrientes fósforo, potássio e enxofre foram aplicados como adubação bäsica e nas dosagens de $100 \mathrm{~kg} \mathrm{P}_{2} \mathrm{O}_{5} / \mathrm{ha}$, $90 \mathrm{~kg} \mathrm{~K} 20 / \mathrm{ha}$ e $31 \mathrm{~kg} \mathrm{~S} / \mathrm{ha}$. Os sais fornecedores desses nutrien- 
tes foram $\mathrm{NaH}_{2} \mathrm{PO}_{4} \cdot \mathrm{H}_{2} \mathrm{O}$ (389 mg/vaso) e $\mathrm{K}_{2} \mathrm{SO}_{4}(333 \mathrm{mg} / \mathrm{vasO})$ e uma solução contendo os dois sais foi colocada no vaso após o plantio.

Os micronutrientes boro, cobre e zinco, quando aplicados, o foram em conjunto e nas dosagens respectivas de 0,$5 ; 2,0$ e $2,0 \mathrm{~kg} / \mathrm{ha}$. O fornecimento desses nutrientes foi pro cessado através de $\mathrm{H}_{3} \mathrm{BO}_{3}(5,64 \mathrm{mg} / \mathrm{vasO}), \mathrm{CuSO}_{4} \cdot 5 \mathrm{H}_{2} \mathrm{O} \quad(15,75$ $\mathrm{mg} / \mathrm{vaso})$ e quelato de $\operatorname{Zn}(28,57 \mathrm{mg} / \mathrm{vaso})$.

A adição de molibdênio nos tratamentos em que coube, foi executada à base de $0,25 \mathrm{~kg} / \mathrm{ha}$ e na forma de $\mathrm{Na}_{2} \mathrm{MOO}_{4} \cdot 2 \mathrm{H}_{2} \mathrm{O}(1,26 \mathrm{mg} / \mathrm{vasO})$.

A partir da aplicação das soluções e durante tó do o periodo de cultivo das leguminosas, os vasos foramirrigados duas vezes por dia, com àgua destilada e deionizada.

Apōs a germinação das plantas, procedeu-se a desbastes periódicos até que, em 15 e 16.04 .75 realizou-se um desbaste final em todos os vasos, deixando-se cinco plantas em cada vaso.

\subsection{Delineamento experimental}

Empregou-se o delineamento de blocos ao acaso, com dezesseis tratamentos e três repetições para cada uma das espēcies em separado.

Os níveis de calagem correspondentes a $0 ; 0,83$; 1,66 e 2,49 toneladas de calcārio por hectare serão designa dos simplesmente sob a forma respectiva de calagem $0 ; 1 ; 2$ e 3. 
Os tratamentos empregados, foram os seguintes:

1. Calagem 0 - sem micronutrientes

2. Calagem $0+$ Mo

3. Calagem $0+(B+C u+Z n)$

4. Calagem $0+(M o+B+C u+Z n)$

5. Calagem 1 - sem micronutrientes

6. Calagem $1+$ Mo

7. Calagem $1+(B+C u+Z n)$

8. Calagem $1+($ Mo $+B+C u+Z n)$

9. Calagem 2 - sem micronutrientes

10. Calagem $2+$ Mo

11. Calagem $2+(B+C u+Z n)$

12. Calagem $2+\left(M_{0}+B+C u+Z n\right)$

13. Calagem 3 - sem micronutrientes

74. Calagem $3+$ Mo

15. Calagem $3+(B+C u+Z n)$

16. Calagem $3+\left(M_{0}+B+C u+Z n\right)$

3.7. Colheitas

A centrosema e o siratro sofreram um ünico corte no experimento, enquanto a soja perene e a galactia foram submetidas a dois cortes.

Em 12.05.75, cerca de 54 dias após o plantio, procedeu-se ao corte único do siratro e ao primeiro corte da soja perene e da galactia.

o ūnico corte da centrosema foi realizado em 
02.06.75, ou seja 75 dias apōs a semeadura.

o segundo e ūltimo corte da soja perene e da galactia foi executado, respectivamente, em 23.06 .75 (cerca de 42 dias apōs o primeiro corte) e em 30.06.75 (49 dias apōs o primeiro corte).

Depois do corte final de cada espécie, as raízes eram separadas do solo através de jatos de àgua corrente. A seguir, procedeu-se à retirada dos nōdulos para, inicialmen te, serem contados. Uma vez feito isso, as raízes foram lavadas com āgua destilada e deionizada.

Todo o material colnido (parte aērea, raízes e nödulos) sofreu secagem a $65^{\circ} \mathrm{C}$ em estufa de circulação forçada de ar, durante 48 horas.

Estando secas, a parte aērea, as raīzes e os nō dulos foram pesados separadamente.

o material da parte aérea e das raízes de cada vaso foi moido em separado em moinho tipo whiley e acondicionado em frascos de vidro fechados com tampa plāstica.

3.8. Amostragens de solo.

Um dia antes do plantio das leguminosas (em 18.03.75) procedeu-se a uma amostragem de solos, retirando-se, com uma espätula de aço inox, pequenas porções de solo em cada vaso, de acordo com os niveis de calagem utilizados. Dessa forma, coletou-se quatro amostras (calagem $0 ; 1 ; 2$ e 3 ) para cada leguminosa. 
Por ocasião do corte final de cada espécie, apōs retirada a parte aērea da planta e antes da lavagem das raízes uma nova amostragem de solo foi realizada. Com uma espátula de aço inox, retirou-se as amostras, tratamento por tratamento, mas unindo-se as três repetições de cada ensaio numa só amos tra composta. Assim, foram coletadas dezesseis amostras para cada uma das espécies forrageiras.

3.9. Anāilises químicas das plantas.

Em todo material proveniente da parte aērea das leguminosas procedeu-se à determinação dos teores de nitrogê nio, fósforo, cālcio, magnésio, potāssio, boro, cobre, ferro, manganês e zinco. Nas raízes moídas fez-se a determinação dos teores de nitrogênio.

o nitrogênio foi determinado pelo método semi-mi cro Kjeldahl, usando óxido de mercūrio como catalisador (LOTT et alii, 1956).

Na determinação do boro empregou-se o mētodo da curcumina, com leituras no colorỉmetro fotoelétrico klett-summerson (SARRUGE e HAAG, 1974 ).

A extração nitrico-perclōrica foi utilizada como ponto de partida para as demais determinações (SARRUGE e HAAG, $1974)$

o fósforo foi determinado pelo método do vanadomolibdato de amōnio, com leituras no colorimetro fotoelétrico Klett-Summerson (SARRUGE e HAAG, 1974).

Para a determinação do cālcio fez-se uma dilui- 
ção inicial da alíquota do extrato com óxido de lantānio e pro cedeu-se à leitura em espectrofotómetro de absorção atômica Perkin-Elmer, modelo 306 (PERKIN-ELMER, 1976).

As demais leituras de magnésio, potássio, cobre, ferro,manganès e zinco, foram executadas em espectrofotómetro de absorção atōmica Perkin-Elmer, modelo 306 (PERKIN-ELMER, $1976)$

\subsection{Anālises químicas de solos}

Em todas as amostras coletadas foram determina dos pH; aluminio, cālcio, magnésio e potássio trocāveis e fósforo solūvel (CATANI e JACINTHO, 1974).

o pH foi obtido por leitura em potenciómetro, de uma suspensão aquosa, na relação $1: 2,5$.

Para a determinação de aluminio, de cālcio e de magnésio trocāveis empregou-se a extração com cloreto de potás sio. Para o alumínio, fez-se a titulação final com solução de hidróxido de sōdio, enquanto o cálcio e o magnésio foram lidos no espectrofotōmetro de absorção atōmica, Perkin-Elmer, modelo 303.

Determinou-se o potássio trocāvel por fotometria de chama, apōs extração com àcido sulfūrico.

A extração do fósforo solūvel foi executada por àcido sulfūrico, com a sequente adição de reativo sulfo-bismuto-molíbdico e ácido ascórbico para posterior leitura em colorimetro fotoelétrico klett-Summerson.

A determinação da matéria orgānica foi realizada 
via carbono, por colorimetria, apōs oxidação do material com dicromato de potássio*.

$\mathrm{Na}$ primeira sērie de amostras de solo (dezesseis amostras antes do plantio) e nas amostras colnidas nos vasos cultivados com centrosema, procedeu-se $\vec{a}$ determinação tambēm de hidrogēnio mais aluminnio trocāveis. Uma vez que se determinou o aluminio trocável, por diferença calculou-se o hidrogé nio irocāvel.

Fez-se a determinação do hidrogēnio mais alumí nio trocáveis por extração com acetato de cālcio pH 7,0 e titú lação com hidróxido de sódio (CATANI e JACINTHO, 1974).

3.11. Anälises estatisticas

A anālise estatística de todos os dados obtidos baseou-se em PIMENTEL GOMES (1970) e foi processada em computa dor eletrónico IBM, modelo 1130.

os dados obtidos para número e peso de nōdulos foram transformados em raiz quadrada antes de serem analisados estatisticamente.

Na anălise de variância dos dados obtidos para as plantas cuidou-se de decompor os três graus de liberdade dos nĩveis de calagem enquanto o efeito dos tratamentos de micronu trientes foi analisado dentro de cada nivel de calagem.

0 teste $F$ foi usado para se determinar as signif $\underline{j}$

* Comunicação pessoal do Engọ Agrọ J.A. QuAGGIO - Seção de Fer tilidade do solo - Instituto Agronōmico - Campinas, SP. 
câncias dos tratamentos e para o caso da calagem, as regres sões significativas tiveram suas equações calculadas. 
4. RESULTADOS E DISCUSSAOO

4.1. Efeitos químicos da calagem no solo.

Os dados obtidos nas anālises químicas das amos tras de solo e coletadas nos vasos, um dia antes do plantio das leguminosas, são apresentados na Tabela 1. A Figura 1 ilustra as variações ocorridas no $\mathrm{pH}, \mathrm{Al}^{3+}$ trocāvel e $\left(\mathrm{Ca}^{2+}+\right.$ $\mathrm{Mg}^{2+}$ ) trocāveis, na porcentagem de saturação de bases, na por centagem de saturação de aluminio, em função de níveis de calagem aplicados.

Pode-se verificar (Tabela l) que a aplicação do calcärio dolomitico ao solo resultou em elevações do pH, do cálcio e do magnēsio trocáveis, da soma de bases permutáveis (S), da capacidade de troca de cátions (T), bem como da por centagem de saturação de bases (V). Paralelamente, a calagem 
proporcionou reduções no alumīnio e hidrogēnio trocāveis e na porcentagem de saturação de aluminio $(m)$. Variações desse tipo são amplamente mencionadas na literatura, como por BUCKMAN e BRADY (1968), KAMPRATH (1972), TISDALE e NELSON (1975), CAMARGO e VAN RAIJ (1976) e MALAVOLTA (1976).

\footnotetext{
Tabela 1. Resultados das anälises quimicas do solo, em amostras

tomadas 40 dias após a calagem e um dia antes do plan

tio das leguminosas. Médias de quatro repetiçōes.
}

\begin{tabular}{|c|c|c|c|c|c|c|c|c|c|c|c|c|}
\hline \multirow{2}{*}{$\begin{array}{l}\text { Nivel } \\
\text { de } \\
\text { calagem }\end{array}$} & \multirow{2}{*}{$\underset{i}{M . O}$} & \multirow{2}{*}{$\mathrm{pH}$} & \multicolumn{8}{|c|}{ equivalentes-miligrama por $100 \mathrm{ml}$ T.F.S.A. } & \multirow{2}{*}{$v^{2}$} & \multirow{2}{*}{$m^{b}$} \\
\hline & & & $A 1^{3+}$ & $\mathrm{Ca}^{2+}$ & $x_{g}{ }^{2+}$ & $\mathrm{x}^{+}$ & $\mathrm{PO}_{4}^{3-}$ & $\mathrm{H}^{+}$ & $\mathrm{s}$ & $\tau$ & & \\
\hline 0 & 2,1 & 4,7 & 0,80 & 0,30 & 0,10 & 0,07 & 0,03 & 2,62 & 0,47 & 3,89 & 12.1 & 63,0 \\
\hline 1 & 2,1 & 5,1 & 0,40 & 0,62 & 0,30 & 0,07 & 0,03 & 2,60 & 0,99 & 3,99 & 24,8 & 28,8 \\
\hline 2 & 2,1 & 5,4 & 0,20 & 0,90 & 0,45 & 0,07 & 0,03 & 2,48 & 1,42 & 4,10 & 34,6 & 12,3 \\
\hline 3 & 2,1 & $5, E$ & 0,08 & 1,18 & 0,60 & 0,07 & 0,03 & 2,20 & 1,85 & 4,13 & 44,8 & 4,1 \\
\hline
\end{tabular}

a. Calculado através da förmula 100.5/T

b. Calculado através da förmula $100 . A 1 /(5+A)$

Por esses dados, constata-se que o pH do solo atingiu um valor máximo de 5,6, quando se aplicou o calcārio pa ra elevar o pH a 6,5. Acredita-se que tal fato tenha ocorrido devido a problemas na solubilidade total do corretivo empregado .

Também, pelos dados da Tabela 1 , pode-se observar que o aluminio trocável do solo tornou-se praticamente nu10 quando o pH atingiu 5,6 e a porcentagem de saturação de bases era de $44,8 \%$. 


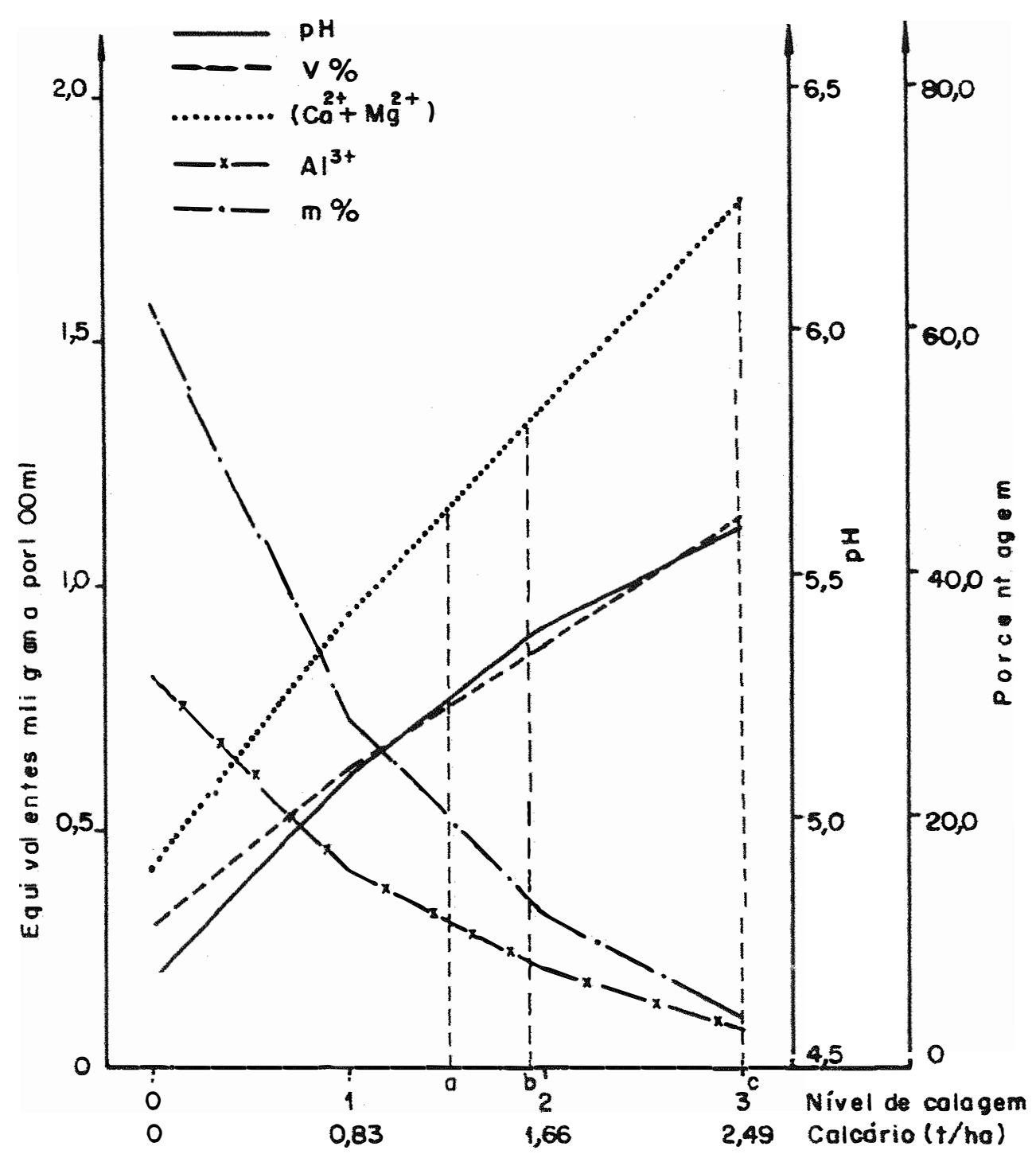

Fig. 1. Variação obtida no $\mathrm{pH}, A \mathrm{l}^{3+},\left(\mathrm{Ca} \mathrm{a}^{2+}+\mathrm{Mg}^{2+}\right), \mathrm{V} \%$ e m\% do solo, mediante os niveis de calagem.

$a, b$ e c - calagem para neutralizar o $\mathrm{Al}^{3+}$ trocāvel $(A) \times 1,5)$, para elevar o $\left(\mathrm{Ca}^{2+}+\mathrm{Mg}^{2+}\right)$ a 2,0 para elevar o pH a 6,5, respectivamente.

KAMPRATH (1972) realça a importância da porcentą gem de saturação de aluminio no solo, enquanto SOARES (1979) 
destaca que esse valor tem-se relacionado melhor com o crescimento das plantas do que apenas o teor de aluminio trocável. Neste sentido, pode-se constatar na Tabela 1 que, com o emprego dos niveis de calagem, a porcentagem de saturação em alumínio no solo, mostrou valores de 63,$0 ; 28,8 ; 12,3$ e $4,1 \%$.

Da Figura 1 pode-se inferir que uma calagem realizada nesse solo, objetivando neutralizar o aluminio trocável (teor de aluminio trocável no solo multiplicado pelo fator 1,5) resultaria, à época dessa amostragem, em $\mathrm{pH}=5,2, \mathrm{Al}^{3+}$ trocāvel $=0,31,\left(\mathrm{Ca}^{2+}+\mathrm{Mg}^{2+}\right)$ trocāveis de 1,11 equivalentes miligrama por $100 \mathrm{mililitros}$ de solo, $\mathrm{V}=29,6 \%$ e $m=21,4 \%$. Dessa mesma forma, pode-se admitir que uma calagem para elevar os teores de cálcio mais magnésio trocáveis ao valor 2,0, resultaria em $\mathrm{pH}=5,4, \mathrm{Al}^{3+}$ trocāvel $=0,21,\left(\mathrm{Ca}^{2+}+\mathrm{Mg}^{2+}\right)$ trocāveis de 1,32 equivalentes miligrama por $100 \mathrm{mililitros}$ de solo, $\mathrm{V}=34,8 \% \mathrm{e}$ $m=13,6 \%$. Ressalte-se, que a calagem para elevar $0 \mathrm{pH}$ a 6,5 proporcionou valores de 5,$6 ; 0,08 ; 1,78 ; 44,8 \%$ e $4,1 \%$ para essas cinco variāveis, respectivamente.

Na Tabela 2 estão os dados coletados nas anālises quimicas das amostras de solo, retiradas no dia da colhe ta final de cada espécie de leguminosa forrageira estudada.

Além da comprovação daqueles efeitos gerais da calagem já mencionados, pode-se notar na Tabela 2 , que hā ligeiras variações entre os dados obtidos para as diferentes espécies cultivadas. Cabe aqui ressaltar que as amostras de solo foram coletadas em épocas diferentes, portanto propiciando di- 


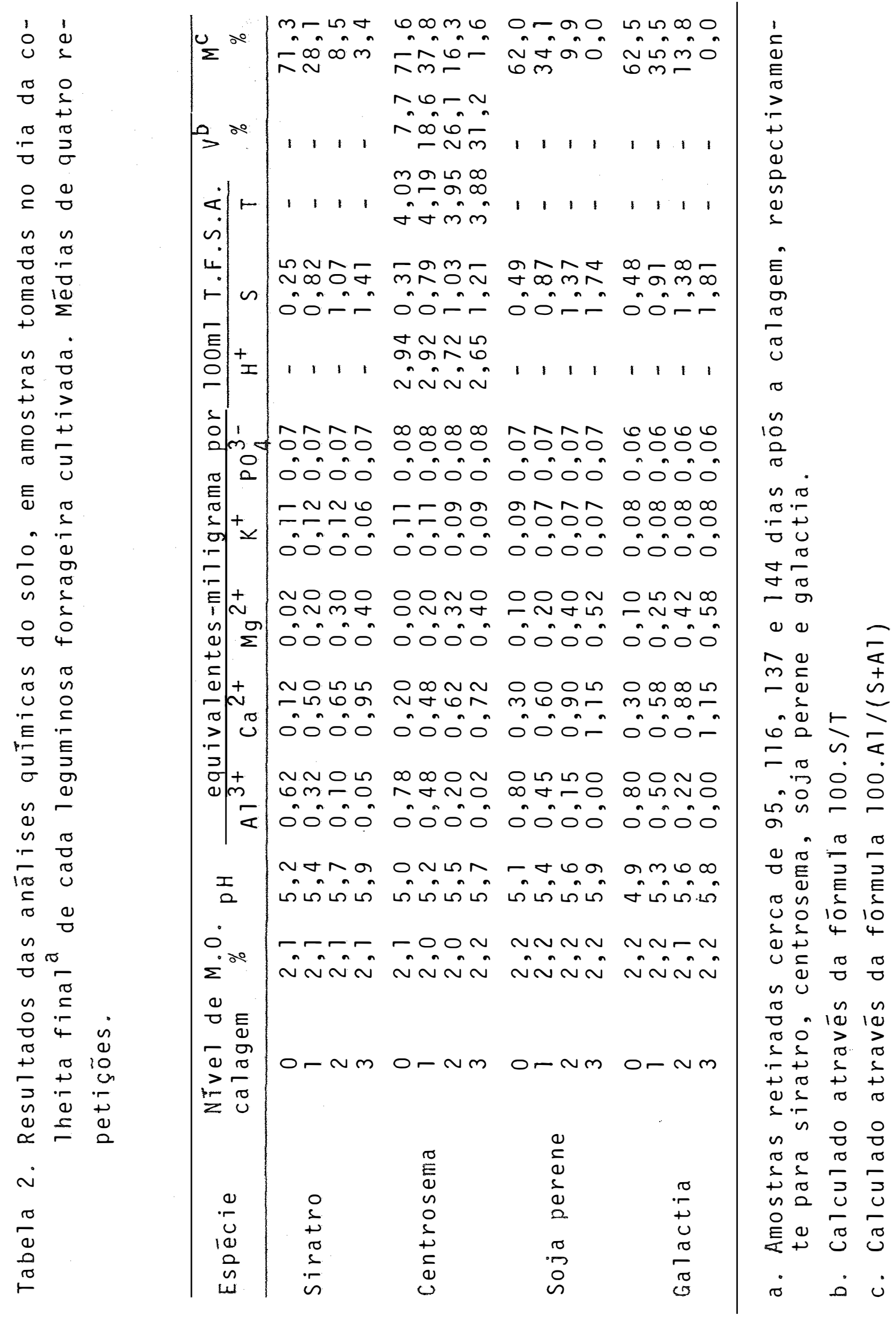


ferentes períodos de reação do calcārio no solo e de cultivo das plantas.

Tambēm se pode verificar (Tabela 2) que o nivel 1 de calagem $(0,83$ toneladas de calcārio por hectare) reduzia - teor de alumínio trocável para valores abaixo ou, no máximo, igual a 0,50 equivalentes miligrama por 100 mililitros de so10, que é apontado por WERNER (1977), como o valor crítico no solo com pastagem formada com a maioria das espécies forrage ras tropicais.

0 nível máximo de calagem empregada (2,49 toneladas de calcārio por hectare) è que praticamente anulou o alumínio trocável no solo (Tabela 2) e elevou a soma do cálcio e do magnésio trocáveis a valores pröximos de 1,5 equivalen tes miligrama por 100 mililitros de solo. Esses valores, embo ra sendo baixos, estão acima do valor crítico para solo com pastagem (de 1,0 equivalente miligrama por 100 mililitros de solo) apontado por WERNER (1977).

4.2. Efeitos da calagem nas leguminosas.

Embora todos os dados obtidos tenham sido anali sados conjuntamente (calagem e micronutrientes) optou-se por apresentar em primeiro lugar aqueles relativos ao efeito geral da calagem e em seguida os dados referentes ao efeito dos micronutrientes dentro de cada nível de calagem.

4.2.1. Soja perene var. Tinaroo

os dados obtidos para a produção de matéria se- 
ca, nitrogênio total, nodulação e teores de macro e micronutri entes na soja perene Tinaroo, em função dos quatro níveis de calagem aplicados, são apresentados nas Tabelas de 3 a 6 . As equações para as regressões significativas são mostradas nas Tabelas 7 e 8 .

Tabela 3. Produção de matéria seca, porcentagem de nitrogēnio e nitrogénio total na parte aérea do 10 corte da soja perene (com 54 dias), em função dos níveis de calagem. Significāncia do teste $F^{\text {a }}$ para os componentes linear, quadrático e cūbico. Médias de 12 dados iniciais.

\begin{tabular}{cccc}
$\begin{array}{c}\text { Niveis } \\
\text { de } \\
\text { calagem }\end{array}$ & $\begin{array}{c}\text { M.S. } \\
\text { g/vaso }\end{array}$ & $\begin{array}{c}N \\
\%\end{array}$ & $\begin{array}{c}\text { N total } \\
\text { (mg/vaso) }\end{array}$ \\
\hline 0 & 1,83 & 3,75 & 67 \\
1 & 4,26 & 1,79 & 76 \\
2 & 5,03 & 1,74 & 88 \\
3 & 5,80 & 1,75 & 101 \\
Reg.linear & $\star \star$ & $\star \star$ & $\star \star$ \\
Reg.quadr. & $\star \star$ & $\star \star$ & ns \\
Reg.cübica & $\star$ & $\star \star$ & ns \\
\hline
\end{tabular}

a. * e ** = significâncias aos niveis de $5 \%$ e $7 \%$ de probabilidade, respectivamente. $n s=$ não significativo 


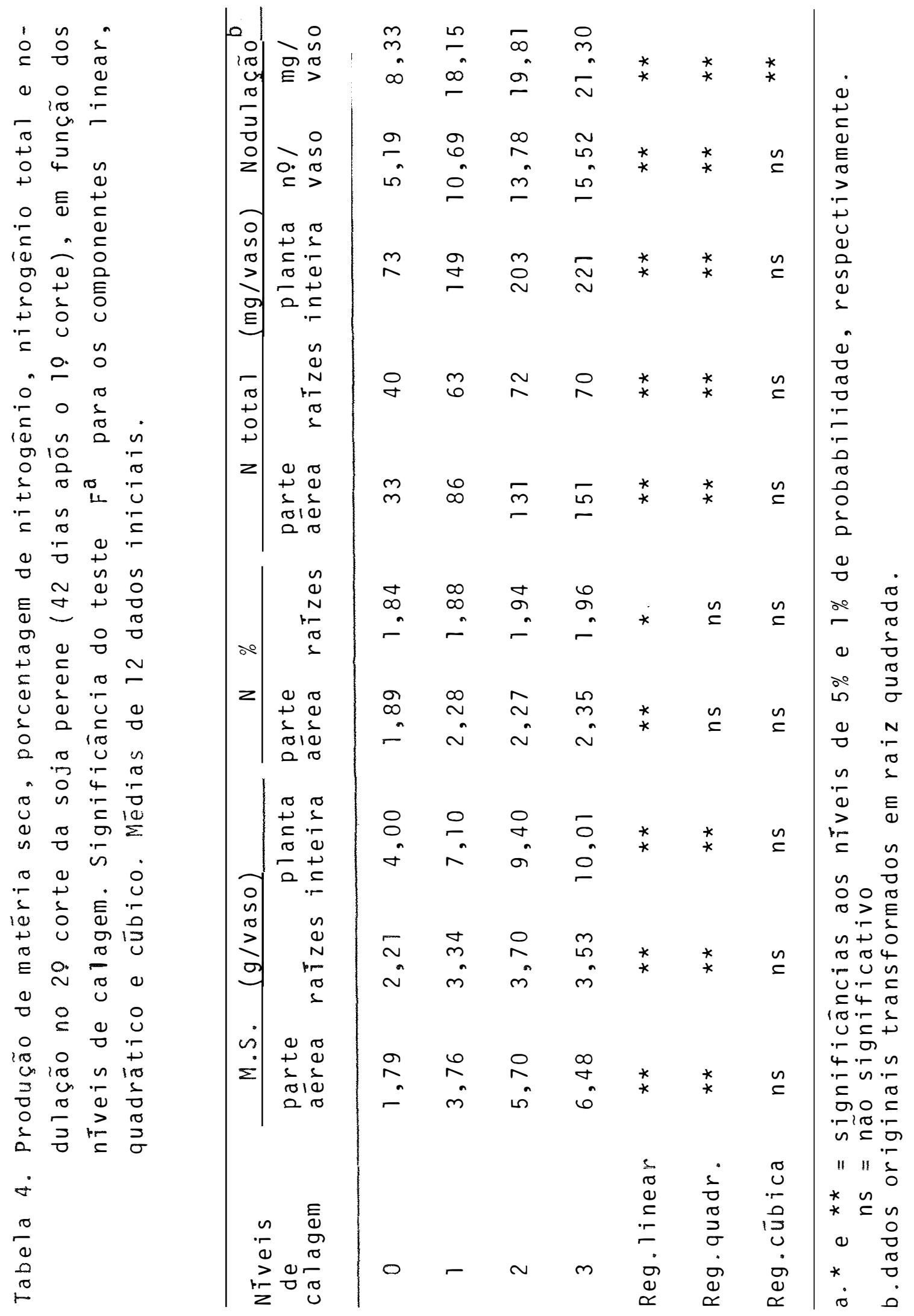


As produções de matēria seca da parte aērea veri ficadas no primeiro e segundo cortes (Tabelas 3 e 4 ) bem como das raizes e planta inteira no segundo corte (Tabela 4 ) foram significativamente aumentadas pela calagem (Tabelas 7 e 8 ), 0 que está concordando plenamente com a grande maioria dos estudos envolvendo essa espécie. Em termos de produção da parte aërea, ao se comparar o nível 0 de calagem ( $p H$ final $=5,1$ e $\mathrm{A} 7^{3+}=0,8$ equivalentes miligrama por $100 \mathrm{mililitros}$ de solo) com o nível 4 ( $p H$ final $=5,9$ com aluminio trocável de valor nulo) nota-se que o primeiro representou cerca de $30 \%$ do segun do, em ambos os cortes, confirmando a sensibilidade da soja pe rene Tinaroo às condições de acidez do meio (SOUTO e DÖBEREINER, 1969 e JONES e FREITAS, 1970). Em ambos os cortes, a soja perene teve sua produção aumentada até a máxima dose de calcário utilizada.

A porcentagem de nitrogēnio na parte aérea da planta, por ocasião do primeiro corte (Tabela 3) mostrou sensi vel redução quando se aplicou as duas primeiras doses de calcā rio no solo. Esse decréscimo foi simultāneo a um aumento de grande magnitude na produção de matēria seca da parte aérea, o que leva a atribuir a queda do teor de nitrogénio a um efeito de diluição do elemento na planta. Todavia, na presença de calagem, as porcentagens de nitrogēnio constatadas são inferiores aos 2,04 a 2,25\% observados por SOUTO e DÖBEREINER (1969) e aos $2,18 \%$ (em tratamento completo) por JONES et alii (1970). Isto leva a supor que ao tempo do primeiro corte a nodulação 
dessa espécie ainda não estivesse em pleno funcionamento.

Jà à ēpoca do segundo corte, pode-se verificar (Tabela 4) que a calagem resultou em significativos aumentos lineares (Tabela 8) no teor de nitrogēnio na parte aērea e nas raízes. Também os valores porcentuais desse elemento na parte aērea, não obstante o aumento da produção de matéria seca, foram os mais altos nos niveis mais elevados de calagem. Efeitos da calagem, semelhantes a esse, foram constatados em soja perene por JONES e FREITAS (1970) e por FRANÇA et alii (1973). Os teores de nitrogēnio na parte aérea da soja perene, no segundo corte, estão ligeiramente acima daqueles observados por SOUTO e DÖBEREINER (1969) e por JONES et alii (1970), evidenciando o bom desempenho da simbiose nessa ēpoca e nos tratamentos com calagem.

0 nitrogēnio total, em ambos os cortes efetuados nessa planta (Tabelas 3 e 4 ), foi significativamente aumentado como efeito da calagem (Tabelas 7 e 8). Aumentos nessa. variá vel, devido à calagem, também foram verificados com soja perene, por FRANÇA e CARVALHO (1970), JONES et alii (1970), EIRA et ali (1972), TRIGOSO e FASSBENDER (1973) e CARVALHO et ali $(1974)$.

A nodulação dessa espécie, expressa em termos de nümero ou de peso dos nódulos secos por vaso (Tabela 4), foi significativamente incrementada pela calagem (Tabelas 7 e 8), o que está de acordo com TRIGOSO e FASSBENDER (1973) e MUNNS et alii (1977). Nesse aspecto, alēm da influēncia no maior de- 
senvolvimento das plantas com o consequente maior fornecimento de fotossintetizados (NEYRA, 1978) a calagem deve também ter melhorado o suprimento de cālcio e de magnēsio para os nödulos (NORRIS, 1959 e MUNNS, 1970).

Os teores dos nutrientes analisados na soja pere ne, alēm do nitrogēnio, são apresentados nas Tabelas 5 e 6 . De um modo geral pode-se verificar que os valores encontrados estão dentro de valores normalmente apresentados na literatura (JONES e FREITAS, 1970; FRANÇA et alii, 1973; WERNER et alii $1975^{\mathrm{a}}$ e MIRANDA, 1979), salientando-se, contudo, as concentrações relativamente mais elevadas para fósforo, cālcio, magnēsio e potássio no material colhido no primeiro corte do experi mento. Para esses teores de cālcio e potássio, especialmente altos nas plantas crescidas no nível 0 de calagem (Tabela 5), obviamente teria ocorrido uma concentração desses elementos, por falta de maior crescimento da planta.

As porcentagens de fósforo e de potássio na legu minosa (Tabelas 5 e 6 ) decresceram significativamente em função da calagem (Tabelas 7 e 8), em ambos os cortes. Redução na porcentagem de fósforo, quando comparou o tratamento sem calagem e sem cálcio com o tratamento completo na soja perene, foi verificada por MIRANDA (1979), enquanto reduções nos teores de potássio devido à calagem são relatados por JONES e FREITAS (1970) e MIRANDA (1979). Esses decréscimos seriam resultado de uma diluição dos nutrientes no interior da planta.

o teor de cálcio na parte aérea da soja perene 


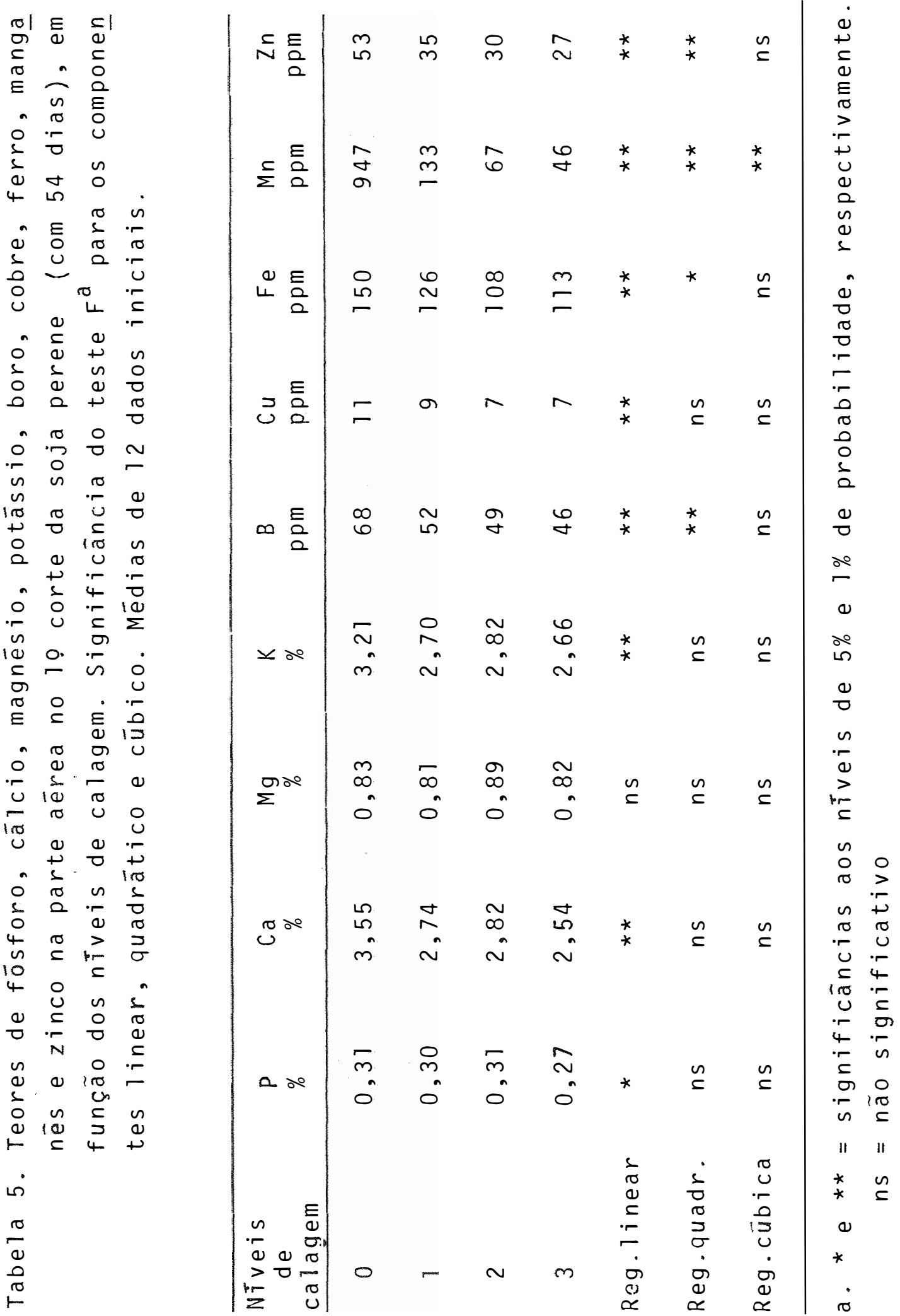




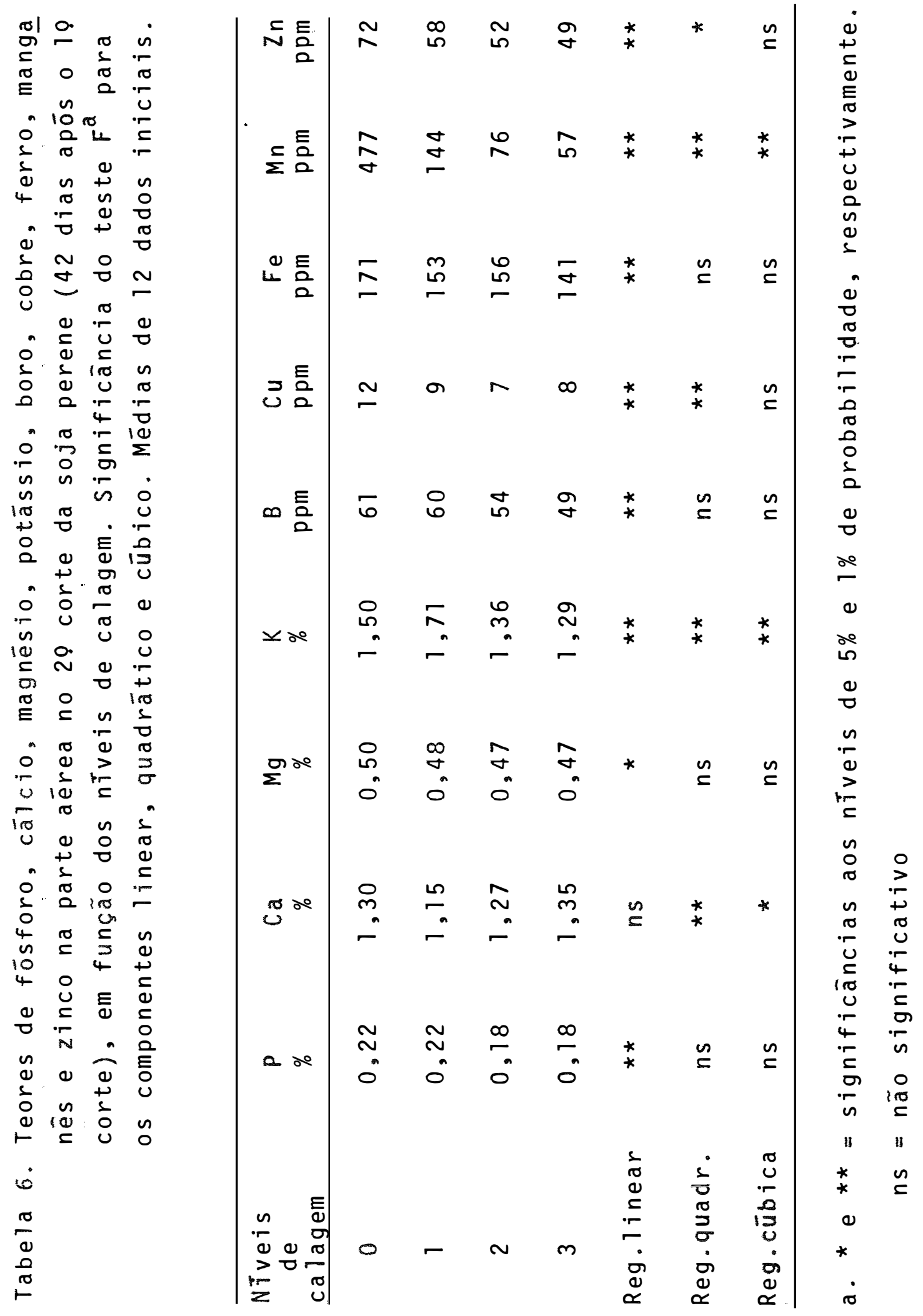


cultivada em calagem 0 proveniente do segundo corte (Tabela 6) mostrou novamente um efeito de concentração do elemento. Quando se considera. os teores nas plantas cultivadas em presença de calagem, nota-se uma concentração ascendente com a elevação do nīvel de calagem. Observação semelhante é descrita por JoNES e FREITAS (1970), EIRA et alii (1972), FRANÇA et alii (1973) e MIRANDA (1979).

A porcentagem de magnésio na leguminosa (Tabelas 5 e 6) não sofreu variações em relação à calagem, no primeiro corte, enquanto mostrou decréscimos significativos e lineares (Tabela 8) no segundo corte. Esse tipo de redução não tem sido comumente relatada, mas dado o fato de ela ser de baixa magnitude enquanto os aumentos na produção de matēria seca foram muito mais expressivos, a quantidade de magnésio absorvida, sem dūvida alguma, foi maior com a elevaçäo da calagem.

os teores de boro, cobre, ferro, manganês e zinco nos materiais colhidos da soja perene (Tabelas 5 e 6) sofre ram significativos decréscimos com as doses de calagem emprega das (Tabelas 7 e 8). Isso está de acordo com o relatado por LINDSAY (1972) quanto à redução da disponibilidade desses micronutrientes pela calagem, e também com os resultados obtidos por JONES et alii(1970) e MIRANDA (1979). Mesmo considerando as máximas reduções verificadas, de acordo com Andrew citado por JONES e FREITAS (1970), os teores de boro, cobre e zinco não seriam deficientes para a leguminosa.

Cabe ressaltar os altos teores de manganès veri- 
ficados na parte aērea da planta, no primeiro corte (Tabela 5). no nível 0 de calagem ( $p H$ final $=5,1)$. De acordo com Andrew, citado por JONES e FREITAS (1970) uma concentração maior que 450 ppm de manganès na soja perene deve resultar em toxidez do elemento à planta. De fato, em auséncia de calagem, em ambos os cortes os teores de manganès foram superiores a esse valor, especialmente no primeiro corte quando atingiu a 947 ppm de manganês (Tabela 5). Tambēm, durante a condução do experimento na casa-de-vegetação, verificou-se a partir de 10 dias do plan tio, que as primeiras folhas das plāntulas de soja perene cres cidas em nível 0 de calagem ( $p H$ final $=5,1)$ jā começavam a exibir uma clorose nos seus bordos. Com o passar dos dias esta clorose foi se acentuando, tornando-se bem nitida nos bordos e avançando entre as nervuras das primeiras folhas da plan ta. Simultaneamente apareciam pontos necróticos nas äreas cloróticas e as plantas desenvolvidas nos vasos sem calagem, aos 25 dias apōs a semeadura jā exibiam desenvolvimento bem menor que nos vasos com calagem. Essa sintomatologia verificada é idêntica à apresentada por SOUTO e DÖBEREINER (1969); ANDREW e PIETERS (1970) e WERNER et alii (1975 a) para a toxidez de manga nês em soja perene. Os sintomas constatados no presente experi mento são mostrados na Figura 2. 


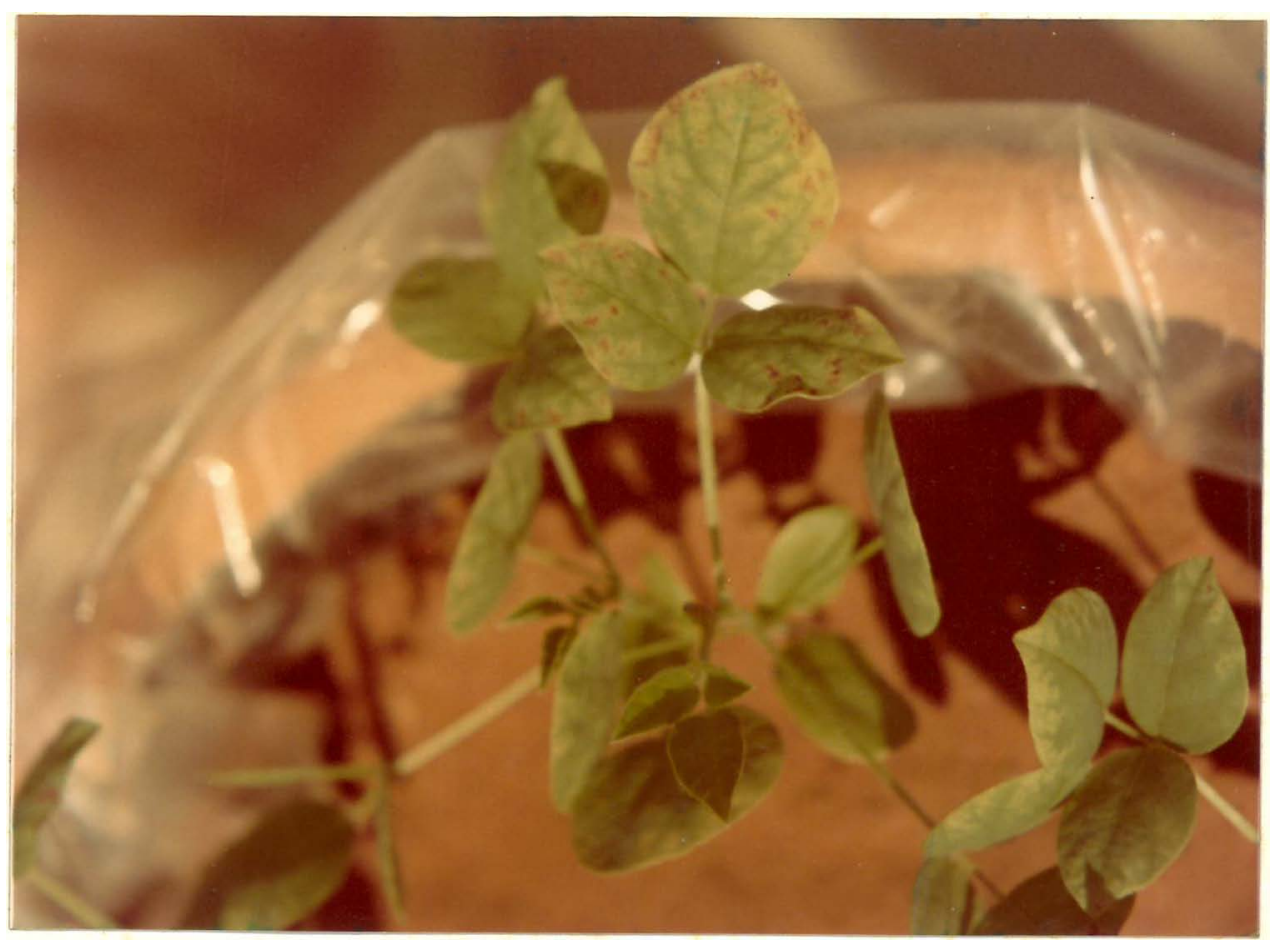

Fig. 2. Sintomas de toxidez de manganes em soja perene Tinaroo, verificados nos tratamentos sem calagem.

De acordo com as informações disponíveis na lite ratura (SOUTO e DÖBEREINER, 1969 e FRANCO e DÖBEREINER, 1971) o efeito da toxidez de manganés afetaria mais o desenvolvimento da nodulação que o da planta em si. Assim, tentou-se correlacionar os dados obtidos por ocasião do segundo corte da soja perene, de teores de manganès na parte aérea com o peso de nódulos e com a produção de matéria seca. Verificou-se que houve correlação negativa e significativa do teor de manganés tanto com a produção de matéria seca da parte aérea $\left(r=-0,83^{\star \star \star}\right)$ como com o peso de nōdulos $\left(r=-0,93^{\star \star \star}\right)$. Embora, se possa ob servar uma relação mais estreita entre o teor de manganés e o 
e o peso de nōduios da soja perene, deve-se acrescentar que a produção de matéria seca dessa leguminosa, também depende em muito da concentração daquele micronutriente. A Figura 3 serve para ilustrar essas observações.

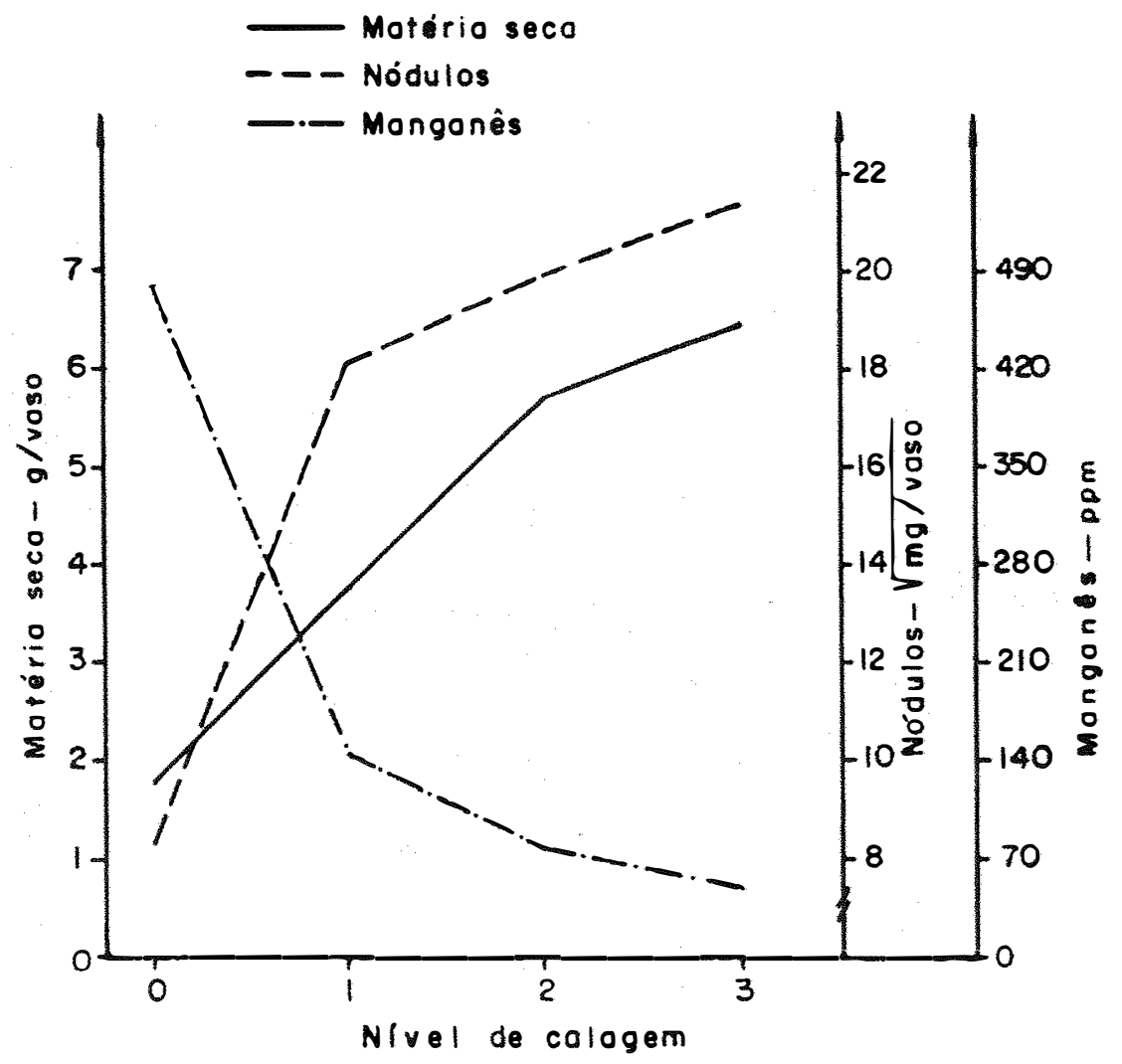

Fig. 3. Relação entre os teores de manganès na parte aérea e peso de nōdulos e produção de matéria seca da soja pẹ rene Tinaroo, obtidos no 20 corte do ensaio.

De acordo com a afirmação de JACKSON (1967) ē muito dificil a separação entre os fatores que afetam o crescimento e/ou nodulação das leguminosas, mas diante dos dados obtidos, hä clara indicação de que um dos principais efeitos benéficos da calagem para a soja perene Tinaroo foi atravēs 
da eliminação da toxidez de manganês.

A variāvel nitrogēnio total depende em alto grau da produção de matēria seca e da eficiēncia da fixação de nitrogēnio pelos nōdulos. Atravēs das equações de regressão obti das para essa variāvel, em função dos nîveis de calagem aplicá dos, (Tabelas 7 e 8 ), pode-se verificar que os valores mäximos para o nitrogēnio total para a soja perene Tinaroo seriam obti dos com doses bem maiores que as utilizadas no presente trabaIho.

Tabela 7. Equações de regressão ${ }^{a}$ obtidas entre as variāveis es tudadas na soja perene e os niveis de calagem testados ( 0 a $2,49 t / h a)$. Dados referentes ao primeiro cor te da espécie.

\section{Variāvel estudada Equação de regressão}

Matēria seca-p.a. $\quad Y=1,833+4,457 X-2,398 X^{2}+0,480 x^{3}$

Teor de nitrogēnio-\% $Y=3,750-4,124 X+2,748 X^{2}-0,544 X^{3}$

Nitrogénio total-p.a. $Y=65,633+13,815 X$

Teor de fósforo-\% $\quad Y=0,313-0,013 X$

Teor de cálcio-\% $\quad Y=3,353-0,354 X$

Teor de potāssio-\% $Y=3,077-0,183 X$

Teor de boro-ppm $\quad Y=66,958-20,381 X+4,959 X^{2}$

Teor de cobre-ppm $\quad Y=10,650-1,827 X$

Teor de ferro-ppm $\quad Y=151,245-41,772 X+10,433 X^{2}$

Teor de manganês-ppm $Y=947,000-1656,324 X+1055,676 X^{2}-205,568 X^{3}$

Teor de zinco-ppm $\quad Y=52,400-24,016 X+5,685 X^{2}$

a. Y é o valor para a variāvel estudada enquanto X $\bar{e}$ a dose de calcārio aplicada, dentro dos limites testados. 
Tabela 8. Equações de regressãoa obtidas entre as variāveis es tudadas na soja perene e os niveis de calagem testados ( 0 a $2,49 \mathrm{t} / \mathrm{ha})$. Dados referentes a segundo corte da espécie.

Variāvel estudada

Equação de regressäo

\begin{tabular}{ll}
\hline Matéria seca-p.a. & $Y=1,731+3,004 X-0,432 X^{2}$ \\
Matéria seca-raiz & $Y=2,219+1,697 X-0,472 X^{2}$ \\
Matéria seca-pl.int. & $Y=3,951+4,702 X-0,904 X^{2}$ \\
Teor de nitrogênio-p.a.-\% & $Y=1,991+0,165 X$ \\
Teor de nitrogênio-raiz-\% & $Y=1,837+0,054 X$ \\
Nitrogênio total-p.a. & $Y=31,783+77,851 X-11,854 X^{2}$ \\
Nitrogènio total-raiz & $Y=40,462+34,392 X-9,163 X^{2}$ \\
Nitrogènio total-pl.int. & $Y=72,245+112,244 X-21,017 X^{2}$ \\
Nodulaçãob-no/vaso & $Y=5,244+7,502 X-1,364 X^{2}$ \\
Nodulaçãob-mg/vaso & $Y=7,825+20,422 X-12,473 X^{2}+2,481 X^{3}$ \\
Teor de fósforo-\% & $Y=0,223-0,018 X$ \\
Teor de cālcio-\% & $Y=1,304-0,449 X+0,417 X^{2}-0,089 X^{3}$ \\
Teor de magnésio-\% & $Y=0,498-0,015 X$ \\
Teor de potássio-\% & $Y=1,499+0,920 X-1,032 X^{2}+0,249 X^{3}$ \\
Teor de boro-ppm & $Y=62,116-4,879 X$ \\
Teor de cobre-ppm & $Y=11,825-4,477 X+1,088 X^{2}$ \\
Teor de ferro-ppm & $Y=168,300-10,532 X$ \\
Teor de manganês-ppm & $Y=477,333-627,623 X+353,101 X^{2}-64,029 X^{3}$ \\
Teor de zinco-ppm & $Y=72,029-18,689 X+3,840 X^{2}$ \\
\hline
\end{tabular}

a. Y é o valor para a variável estudada enquanto $X \bar{e}$ a dose de calcário aplicada, dentro dos limites testados.

b. Dados transformados em raiz quadrada. 


\subsubsection{Centrosema}

Os resultados verificados para a produção de matéria seca, nitrogênio total, nodulação e teores de macro e mi cronutrientes na centrosema, em função das quatro doses de calagem empregadas, são mostrados nas Tabelas 9 e 10 , enquanto as equações correspondentes às regressões significativas constam na Tabela 11.

As produções da matēria seca (parte aērea, raízes e planta inteira) apresentadas na Tabela 9 , foram significativa e linearmente aumentadas (Tabela 11) pela aplicação dos níveis de calcário. Aumentos nessa variável, como um resultado da calagem também foram obtidos por ANDREW e NORRIS (1961), D $\underline{0}$ BEREINER e ARONOVICH (1966), FRANÇA e CARVALHO (1970), JONES et alii (1970), TEITZEL e BRUCE (1973), TRIGOSO e FASSBENDER (1973) e SOARES e VARGAS (1974). Na ausência de calagem a produção de matēria seca da parte aérea da leguminosa foi de cerca de $62 \%$ do máximo alcançado no nível 3 de calagem, o que está bem prōximo dos $52 \%$ verificados por ANDREW e NORRIS (1961).

A porcentagem de nitrogēnio tanto na parte aérea como nas raizes (Tabela 9) sofreu aumento linear e significati vo (Tabela 11) como resultado da adição das doses de calcário. Esse resultado está de acordo com aqueles obtidos por JONES e FREITAS (1970), WERNER e MATTOS (1972), TEITZEL e BRUCE (1973) e SOARES e VARGAS (1974). Os teores de nitrogénio obtidos para a parte aérea (Tabela 9) estão entre os mais baixos obtidos por ANDREW e NORRIS (1961) e são bem menores que os verifica - 

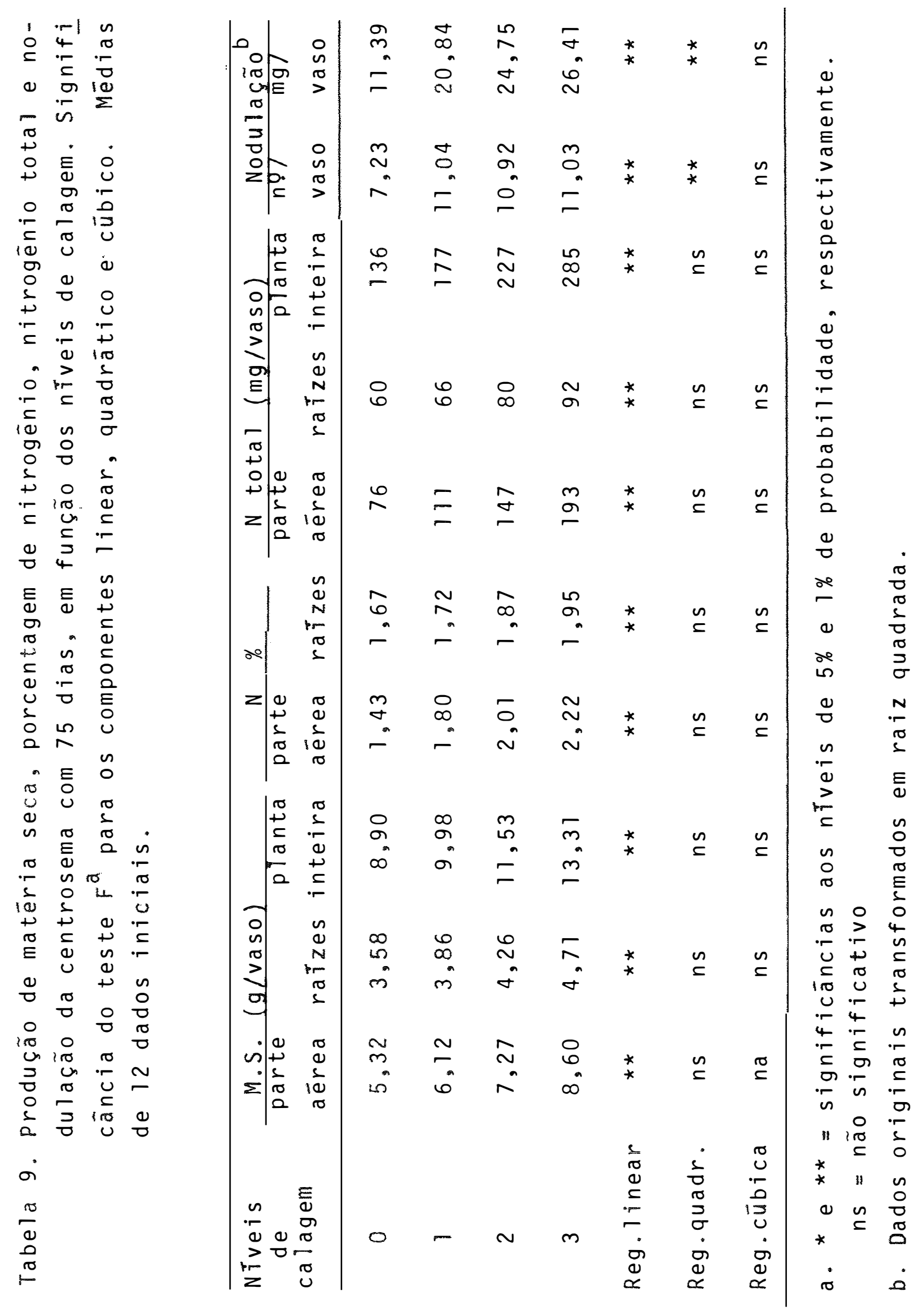


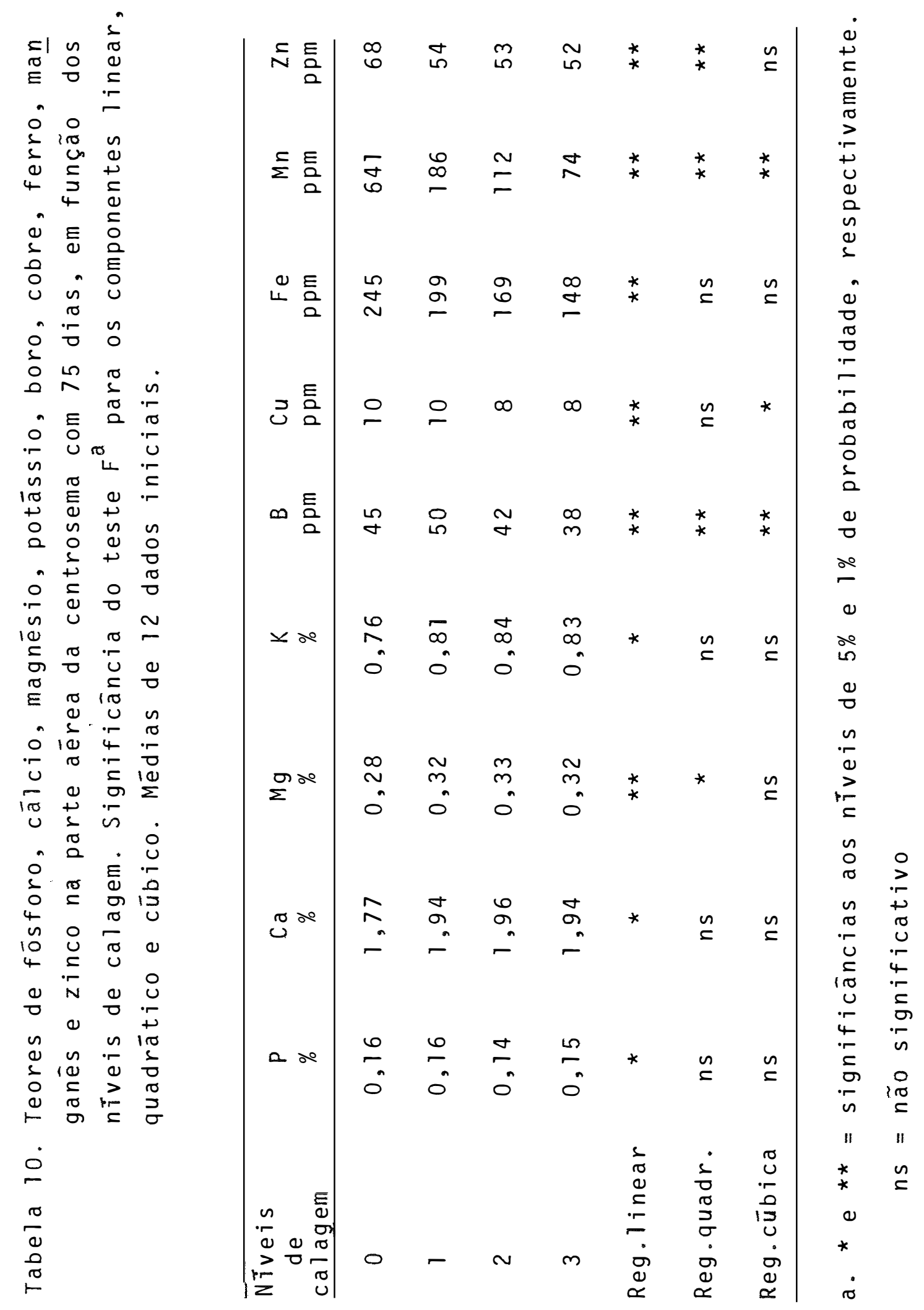


dos por WERNER e MATTOS (1972). Entretanto, os teores desses nu trientes obtidos nos dois niveis mais altos de calagem $(2,01$ e $2,22 \% \mathrm{~N}$ ) são bem superiores àqueles relatados por WERNER e MATTOS (1974).

Tabela 11. Equações de regressão obtidas entre as variāveis estudadas na centrosema e os níveis de calagem testa dos ( 0 a 2,49t/ha). Dados referentes ao corte único da espécie.

Variāvel estudada

Equação de regressão

\begin{tabular}{|c|c|}
\hline Matéria seca-p.a. & $Y=5,178+1,323 x$ \\
\hline Matéria seca-raiz & $Y=3,536+0,456 x$ \\
\hline Matēria seca-pl.int. & $Y=8,714+1,779 X$ \\
\hline Teor de nitrogênio-p.a. $-\%$ & $Y=1,478+0,310 x$ \\
\hline Teor de nitrogénio-raiz-\% & $Y=1,657+0,117 x$ \\
\hline Nitrogēnio total-p.a. & $Y=73,158+46,977 X$ \\
\hline Nitrogènio total-raiz & $Y=58,083+13,253 X$ \\
\hline Nitrogēnio total-pl.int. & $Y=131,241+60,230 X$ \\
\hline Nodulação & $Y=7,441+4,700 x-1,343 x^{2}$ \\
\hline Nodula çãob $-\mathrm{mg} /$ vaso & $Y=11,552+12,945 X-2,829 x^{2}$ \\
\hline Teor de fósforo-\% & $Y=0,160-0,005 X$ \\
\hline Teor de cálcio-\% & $Y=1,879+0,048 x$ \\
\hline Teor de magnésio-\% & $Y=0,285+0,054 X-0,016 x^{2}$ \\
\hline Teor de potāssio-\% & $Y=0,775+0,028 X$ \\
\hline Teor de boro-ppm & $Y=44,833+19,417 X-21,471 X^{2}+4,955 X^{3}$ \\
\hline Teor de cobre-ppm & $Y=10,416+3,434 x-5,624 x^{2}+1,554 x^{3}$ \\
\hline Teor de ferro-ppm & $Y=238,425-38,594 X$ \\
\hline Teor de manganës-ppm & $Y=640,833-881,512 x+522,938 x^{2}-99,492 x^{3}$ \\
\hline Teor de zinco-ppm & $Y=68,266-22,972 X+6,532 x^{2}$ \\
\hline
\end{tabular}

a. Y $\bar{e}$ o valor para a variāvel estudada, enquanto $X \bar{e}$ a dose de calcário aplicada, dentro dos limites testados.

b. Dados transformados em raiz quadrada. 
0 nitrogènio total na parte aērea, nas raízes e por conseguinte na planta inteira (Tabela 9) foi significativa e linearmente (Tabela 11) aumentado com a aplicação das doses de calcário dolomitico. Comparando-se os valores encontrados no nível máximo de calagem com a ausência de aplicação do corretivo constata-se que essa variāvel foi aumentada de 2,$5 ; 1,5$ e 2,1 vezes na parte aérea, raizes e planta inteira, respectivamente. Aumentos no nitrogènio total da centrosema em função da calagem também são realçados pela grande maioria dos trabalhos consultados.

Quanto à nodulação (Tabela 9) verifica-se que a calagem influiu de modo benéfico tanto no nümero quanto no peso de nódulos, sendo esse efeito quadrático (Tabela 11). Esses aumentos concordam com os dados obtidos por ANDREW e NORRIS (1961), DÖBEREINER e ARONOVICH (1966), WERNER e MATTOS (1972) e TRIGOSO e FASSBENDER (1973). O que se constata no número de nódulos (Tabela 9 ) é um substancial aumento quando se adiciona o nível l de calcārio (pH final = 5,2). Jāo peso de nōdulos continua sofrendo acréscimos sensivveis até a aplicaçãodos mais altos nỉveis do corretivo. Como MuNNS (1970) realça a importān cia do cálcio na infecção das raízes durante a formação de nōdulos, é possível que o nível de cálcio disponível, quando se empregou a calagem 1 (teor inicial de cálcio de 0,62 equivalen tes miligrama por $100 \mathrm{mililitros}$ de solo), já era suficiente para estabelecer a nodulação. Entretanto, o maior fornecimento do magnésio teria sido o grande responsável pelo incremento na 
massa nodular, com a elevação da calagem, já que o magnésio de sempenha importante papel na nutrição do Rhizobium (NORRIS, $1959)$.

Com exceção do nitrogēnio (jā discutido), os teo res dos macro e micronutrientes na centrosema, são mostrados na Tabela 10. De um modo geral, verifica-se que os teores estão dentro da normalidade encontrada com essa espécie, em outros trabalhos (ANDREW e NORRIS, 1961; JONES et alii, 1970 e WERNER E MATTOS, 1972 ).

Em termos dos macronutrientes cálcio, magnésio e potássio, o que se nota (Tabelas 10 e 11) é um aumento nos seus teores à medida que se eleva o nível de calagem. A elevação no teor de cálcio da centrosema com a calagem tem sido verificada (ANDREW E NORRIS, 1961, JONES e FREITAS, 1970 e WERNER E MATTOS 1972) e no teor de magnésio, também JONES e FREITAS (1970) obtiveram. Entretanto, um aumento na concentração de potāssio, com a adição de calcário não é relacionada por nenhum desses autores, com centrosema. Fato semelhante ao obtido para o teor de potássio no presente experimento, foi verificado por MIRANDA (1979) com siratro.

Embora a redução linear (Tabela 11) dos teores de fósforo na centrosema, com o acréscimo dos níveis de cala gem (Tabela 10), tenha sido de pequena magnitude, ela chegou a ser estatisticamente significativa. E escassa a citação de teo res desse macronutriente variando em função da calagem e podese verificar que MIRANDA (1979) obteve semelhante variação quan 
do trabalhou com calagem mais cālcio, com soja perene.

Os teores dos micronutrientes boro, cobre, ferro, manganês e zinco na centrosema (Tabelas 10 e ll) mostraram sig nificativos decréscimos com a elevação das doses de calcārio. Resultados semelhantes são mostrados por JONES et alii (1970) e WERNER e MATTOS (1972) e estão de acordo com a afirmativa de LINDSAY (1972) de que as disponibilidades desses elementos são reduzidas com a aplicação da calagem em solos àcidos.

Com relação ao teor de manganês na centrosema cultivada em auséncia de calagem, verifica-se um valor de 641 ppm (Tabela 6). DÖBEREINER e ARONOVICH (1966) citam problemas de toxidez desse elemento em centrosema, quando o teor de manganès na planta era ligeiramente superior a 300 ppm. Também, Andrew, citado por JONES e FREITAS (1970) apresenta como nível critico para a toxidez de manganès uma concentração de 730 ppm do elemento. No presente ensaio não se constatou qualquer sintoma visual de toxidez de manganès na centrosema, entretanto pode-se supor que o alto teor verificado esteja relacionado a efeitos prejudiciais na nodulação dessa leguminosa e consequen temente na fixação do nitrogēnio (SOUTO e DÖBEREINER, 1966 e FRANCO e DÖBEREINER, 1971). Tendo isso em mente é que procurou - se correlacionar os teores de manganés na parte aérea da plan ta com a produção de matéria seca da mesma ou com a nodulação verificada. Assim, constatou-se a correlação negativa do teor de manganés com a produção de matēria seca $\left(r=-0,69^{\star \star *}\right)$ ou com o peso de nōdulos $\left(r=-0,86^{* \star \star}\right)$. Sendo esta correlação mais 
expressiva ( $r$ mais próximo de 1,00 ), confirma-se a maior inflú ència do excesso de manganēs na nodulação que no crescimento da centrosema. A Figura 4 ilustra esses fatos.

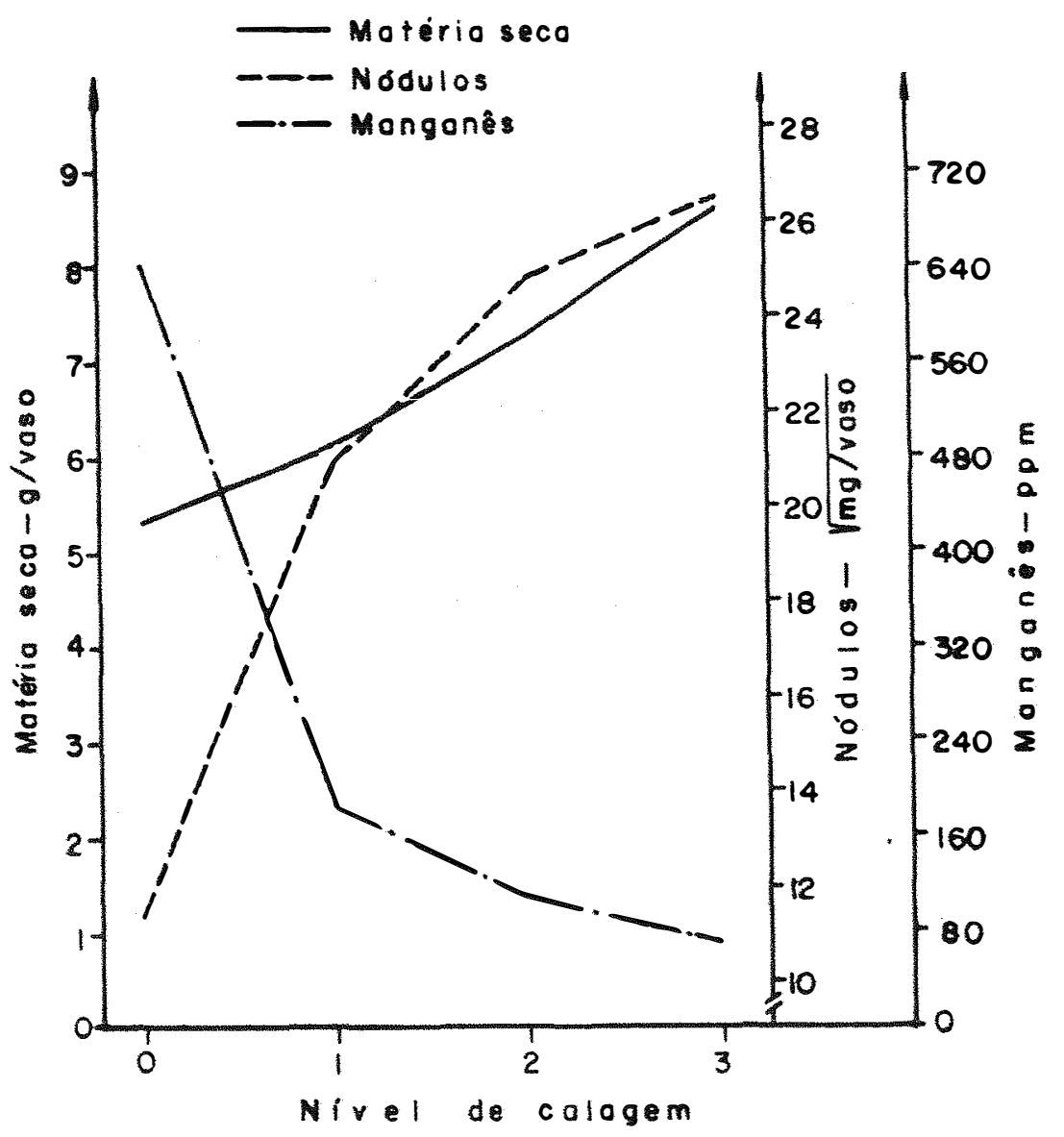

Fig. 4. Relação entre teores de manganès na parte aërea e peso de nōdulos e produção de matéria seca da centrosema.

Observando-se as equações de regressão apresenta das na Tabela 11, para o nitrogénio total e também para produção de matéria seca, em função dos níveis de calagem estudados, verifica-se que os máximos valores para essas variāveis seriam obtidos com doses de calcário superiores às testadas no presen te trabalho. 


\subsubsection{Siratro}

Nas Tabelas 12 e 13 constam os dados obtidos para produção de matéria seca, nitrogēnio total, nodulação e teo res de macro e micronutrientes no siratro, em função dos niveis de calcário empregados. A Tabela 14 mostra as equações correspondentes às regressões significativas.

As produções de matéria seca da parte aērea, raí zes e planta inteira (Tabela 12) variaram significativamente com a calagem (Tabela 14). Acréscimos nesses valores também fo ram obtidos com siratro por FREITAS e PRATT (1969), FRANÇA e CARVALHO (1970), TRIGOSO e FASSBENDER (1973) e CARVALHO et alii (1974). Num exame detalhado desses dados, pode-se verificarque os expressivos aumentas nessas produções se deram com. a aplica ção de 0,83 toneladas de calcārio por hectare ( $\mathrm{pH}$ final $=5,4$ e $A 1^{+++}$trocável $=0,32$ equivalentes miligrama por $100 \mathrm{milili-}$ tros de solo). Aumentos significativos na produção do siratro com a aplicação de doses relativamente baixas de calcário também são relatados por MATTOS (1972) e KOLLING et alii (1974). Há que se acrescentar aqui, que a literatura realmente aponta essa leguminosa como uma das tolerantes à condições de acidez moderada do solo.

Em termos de porcentagem de nitrogēnio (Tabela 12) constata-se que a calagem teve efeito significativo, na parte aérea do siratro, efeito esse que foi linear (Tabela 14). Verifica-se que o teor desse elemento foi acrescido até o máxi mo nivel de calagem utilizado $(2,49$ toneladas de calcário por 


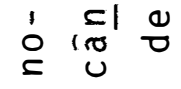

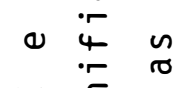

- E .

गु के ठ

$+\infty$ in

$\begin{array}{ccc}0 & \dot{E} & 0 \\ 0 & 0 & u \\ \sigma & 0 & 0 \\ 10 & 0 & 0 \\ \sigma & \frac{0}{10} & 0 \\ 0 & 0 & u\end{array}$

† 0

ᄃ

a n .

.r

c) $>$

(a) r

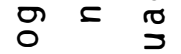

\& $\backsim$ a

$\pm 00$

(1) 0 1

0 in

E 5 드

E

ס 4

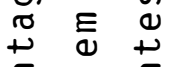

c)

u n

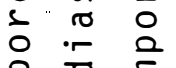

ล ర हิ

$\rightarrow \sigma 0$

ช $n$ n

थ 00

- 0 i

i. 눙 i

id

$\begin{array}{llll}1 & 0 & 1 & 0 \\ E & 1 & 4 & 0\end{array}$

a 0 .

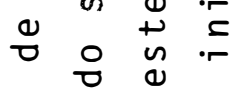

○

iñ in o 잉

บ un o r

$\begin{array}{llll}0 & 0 & & 0 \\ 0 & 5 & 0 & 0 \\ 1 & 0 & 1 & \end{array}$

$\sim$

$\pi$
0
0
1

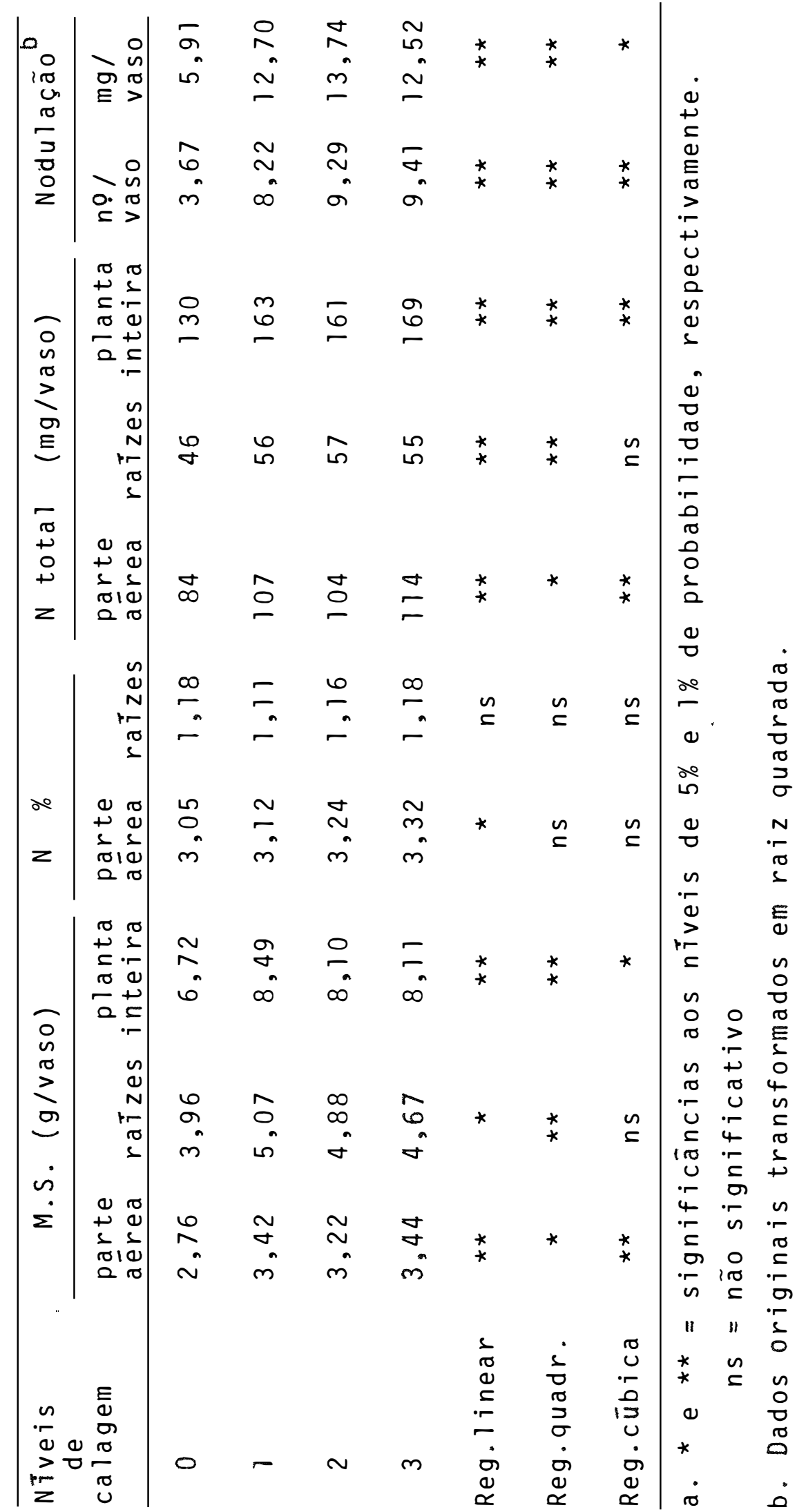


hectare). Elevação na porcentagem de nitrogēnio na parte aērea como resultado da aplicação de calcário, mesmo quando a produção da parte aérea do siratro não aumentava, tambēm foi obtida por BRAZON (1971) e EIRA et alii (1972). o teor de nitrogēnio nas raízes não sofreu alteração pela calagem, o que também foi constatado por BRAZON (1971) e MATTOS (1972).

0 nitrogēnio total no siratro (Tabela 12) foi significativamente alterado como resultado da aplicação de cal cārio. Significativos efeitos da calagem nessa variāvel foram constatados por FRANÇA e CARVALHO (1970), CARVALHO et alii (1971), TRIGOSO e FASSBENDER (1973) e CARVALHO et alii (1974). Embora o nitrogénio total na parte aérea tenha se elevado até a dose mais alta de calcārio ( $p H$ final $=5,9)$, o maior salto nessa variāvel ocorreu quando se passou da dose 0 (pH final= $5,2)$ para a dose 1 de calagem ( pH final $=5,4)$.

Quanto à nodulação da leguminosa (Tabela 12), pode-se constatar o efeito benéfico e segundo uma regressão cūbi ca (Tabela 14) da calagem tanto no nümero quanto no peso de nó dulos. Resultados semelhantes também foram encontrados com siratro por MATTOS (1972) e TRIGOSO e FASSBENDER (1973). 0 nümero de nōdulos foi crescente até a dose máxima empregada, enquanto o peso de nódulos mostrou seu maior valor absoluto na dose 2 de calcārio (1,66 toneladas por hectare). A semelhança do que foi verificado com a produção de matéria seca e nitrogê nio total a nodulação teve seu grande acréscimo com a aplicação do nîvel 1 de calagem $(0,83$ toneladas de calcärio por hectare). 
Os teores de fósforo, cálcio e magnésio na parte aērea do siratro (Tabela 13), sofreram significativos acréscimos mediante a aplicação de calcário (Tabela 14). Aumento no teor de fósforo na leguminosa, como consequéncia da calagem, foi verificado por FRANÇA et alii (1973), enquanto elevações nas porcentagens de cálcio e de magnésio do siratro, em presen ça de calagem, foram observadas por JONES e FREITAS (1970) e MATTOS (1972).

A medida que se elevou a dose de calcārio, 0 teor de potássio no siratro sofreu decréscimo linear (Tabelas 13 e 14), o que foi constatado por JONES e FREITAS (1970). 0 teor de boro na parte aérea (Tabela 8) exibiu um comportamento interessante, em relação à calagem. Contraria mente ao observado por MATTOS (1972), esse micronutriente se mostrou com teor significativamente mais elevado na presença das doses 1 ou 2 do calcário, o que resultou num efeito quadrā tico da calagem para essa variável (Tabela 14).

As concentrações de cobre, manganês e zinco no siratro (Tabela 13) foram significativamente reduzidas mediante o emprego dos níveis de calagem (Tabela 14). Decréscimos em uma ou mais dessas variāveis também são relatados por MATTOS (1972) e GAVAZONI et alii (1979).

Com relação ao manganès, Andrew, citado por joNES e FREITAS (1970) apresenta como nível critico para a toxidez desse elemento um teor de 710 ppm na parte aérea do siratro, enquanto JONES e PRATT (1969) mencionam que essa legumino 

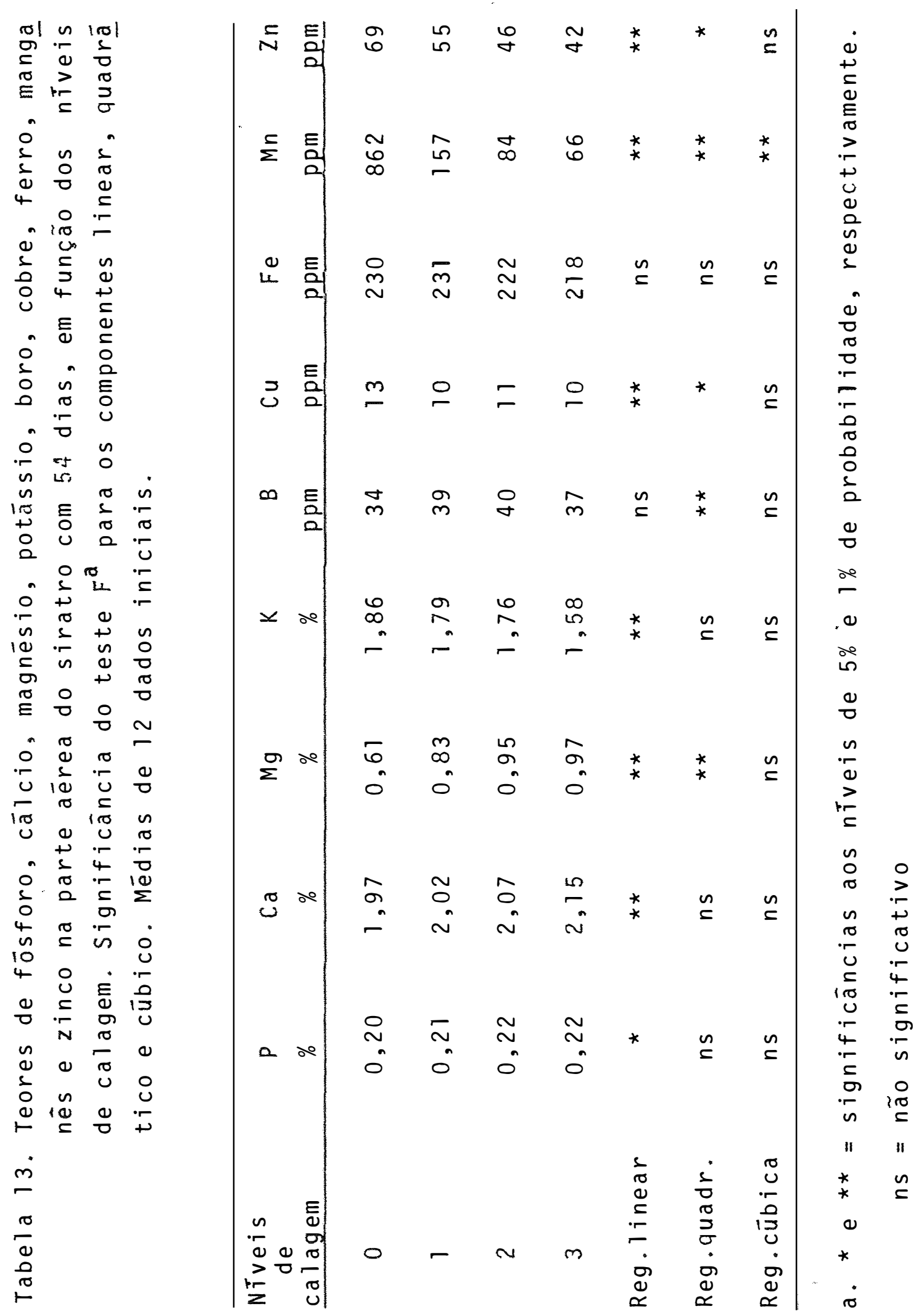
sa seria sensivel à toxidez de manganès. De fato, os menores va lores na produção de matéria seca, no nitrogênio total e na nodulação do siratro foram constatados no nível o de calagem $(p H$ final = 5,2), no qual a leguminosa teve a concentração de 862 ppm de manganês, mas não exibiu qualquer sintoma visual de toxi dez do elemento. Tendo em vista as menções na literatura (SOUTO e DÖBEREINER, 1969 e FRANCO e DÖBEREINER, 1971) de que o excesso de manganès afetaria mais à simbiose Rhizobium - leguminosa, procurou-se correlacionar o teor de manganès na parte aérea,com a produção de matéria seca e com o peso de nōdulos no siratro. Verificou-se que a correlação do teor de manganês com o peso de nōdulos ( $r=-0,90 * \star *)$ realmente é de maior magnitude que a do teor desse micronutriente com a produção de matéria seca da par te aérea da leguminosa $(r=-0,62 * \star *)$. Esses resultados confirmam, com siratro, o que se encontra na literatura referente à outras leguminosas, e no presente trabalho, com soja perene e centrosema. A Figura 5 ilustra essas relações.

Os teores de ferro na parte aérea do siratro (Tabela 13) não variaram significativamente com os niveis de calagem empregados.

Tomando-se o nitrogénio total no siratro como ponto de referência e através da equação de regressão dessa variāvel com as doses de calagem (Tabela 14) pode-se assinalar que o máximo valor para essa variável é obitido com a aplicação de 1,00 tonelada de calcārio por hectare. Com o auxîlio da Figu ra 1 , pode-se verificar que essa dose de calcário, proporciona- 
ria à época do plantio do experimento, os seguintes valores na anälise de solo: $\mathrm{pH}=5,18 ; \mathrm{Al}^{3+}=0,35 ;\left(\mathrm{Ca}^{2+}+\mathrm{Mg}^{2+}\right)=1,03$; $V=27,2 \% \quad m=24,8 \%$.

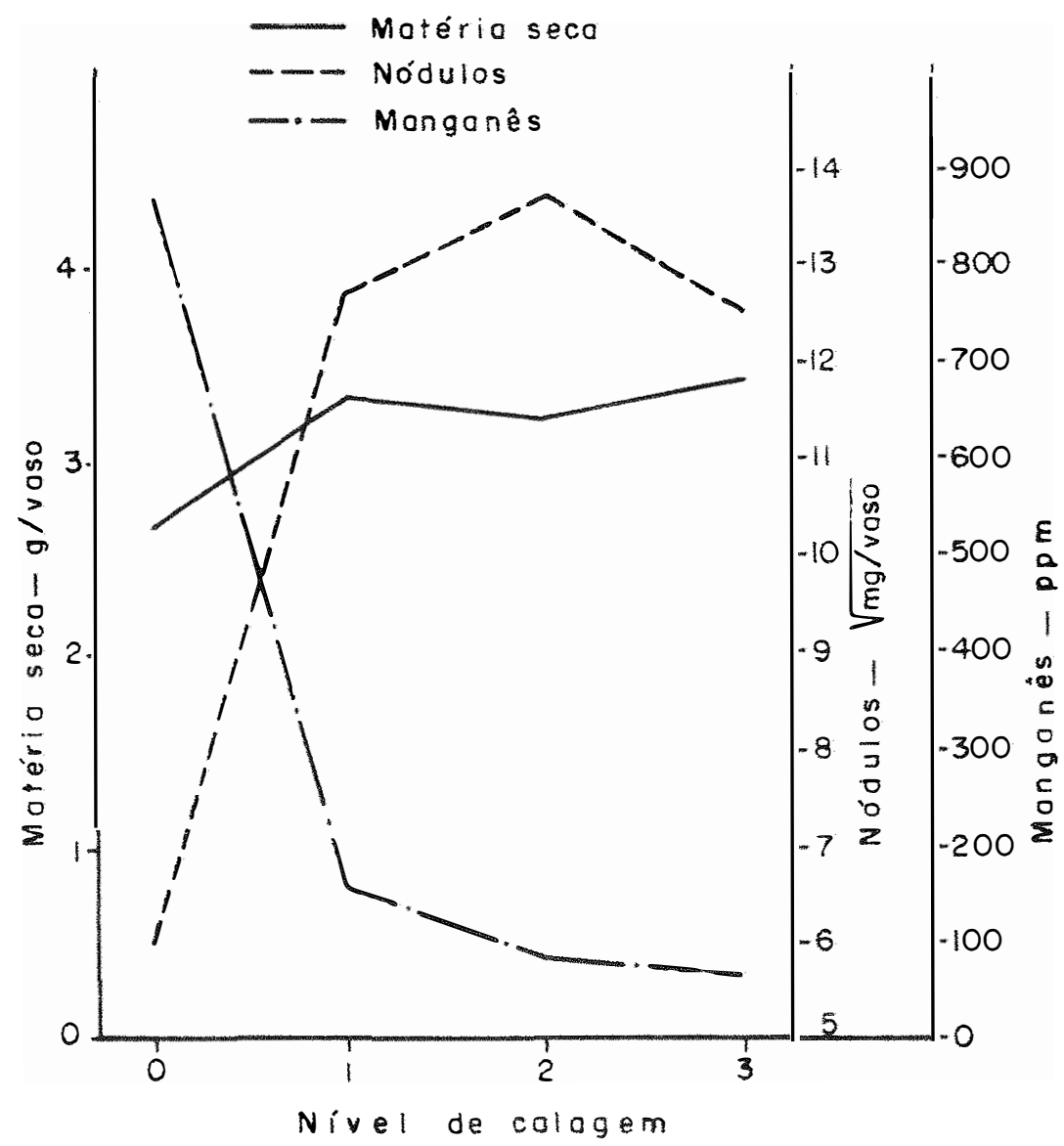

Fig. 5. Relação entre os teores de manganēs na parte aérea e pe so de nōdulos e produção de matéria seca do siratro. 
Tabela 14. Equações de regressãoa obtidas entre as variāveis estudadas no siratro e os niveis de calagem testa dos ( 0 a 2,49t/ha). Dados referentes ao corte ün co da espécie.

Variāvel estudada

Equação de regressão

\begin{tabular}{|c|c|}
\hline Matéria seca-p.a. & $Y=2,754+1,809 x-1,569 x^{2}+0,377 x^{3}$ \\
\hline Matēria seca-raiz & $Y=4,027+1,414 X-0,474 X^{2}$ \\
\hline Matēria seca-pl.int. & $Y=6,718+4,335 x-3,439 x^{2}+0,751 x^{3}$ \\
\hline Teor de nitrogênio-p.a.- & $\% Y=3,043+0,112 X$ \\
\hline Nitrogênio total-p.a. & $Y=83,583+57,691 x-46,148 x^{2}+11,003 x^{3}$ \\
\hline Nitrogènio total-raiz & $Y=46,300+14,267 x-4,415 x^{2}$ \\
\hline Nitrogēnio total-pl.int. & $Y=129,500+78,281 x-58,910 x^{2}+13,238 x^{3}$ \\
\hline Nodulaçãob-nọ/vaso & $Y=3,674+8,247 x-4,345 x^{2}+0,732 x^{3}$ \\
\hline Nodulaçãob-mg/vaso & $Y=5,911+12,452 x-6,713 x^{2}+1,018 x^{3}$ \\
\hline Teor de fósforo-\% & $Y=0,200+0,009 x$ \\
\hline Teor de cālcio-\% & $Y=1,962+0,071 X$ \\
\hline Teor de magnésio-\% & $Y=0,607+0,331 x-0,075 x^{2}$ \\
\hline Teor de potássio-\% & $Y=1,875-0,102 x$ \\
\hline Teor de boro-ppm & $Y=33,512+8,850 x-2,993 x^{2}$ \\
\hline Teor de cobre-ppm & $Y=12,495-2,414 X+0,635 X^{2}$ \\
\hline Teor de manganēs-ppm & $Y=862,000-1410,621 X+877,492 x^{2}-168,113 x^{3}$ \\
\hline Teor de zinco-ppm & $Y=68,666-18,624 X+3,084 X^{2}$ \\
\hline
\end{tabular}

a. Y é o valor para a variável estudada, enquanto $X \bar{e}$ a dose de calcārio aplicada, dentro dos limites testados.

b. Dados transformados em raiz quadrada. 


\subsubsection{Galactia}

Os dados coletados para a produção de matēria se ca, nitrogênio total, nodulação e teores de macro e micronutri entes na galactia, em função dos quatro níveis de calagem empregados, são mostrados nas Tabelas 15 a 18 . As equações corres pondentes às regressões significativas são apresentadas nas Ta belas 19 e 20.

Na Tabela 15 pode-se verificar que, na ocasião do primeiro corte do experimento, a produção de matēria seca e o nitrogénio total da galactia foram linear e significativamente aumentados de acordo com os niveis de calagem (Tabela 19). Esses resultados estão de pleno acordo com aqueles obtidos por MIRANDA (1979) num solo Podzölico Vermelho Amarelo e por MONTEIRO et alij (dados não publicados) em uma Areia Quartzosa de cerrado. A produção de matéria seca, quando não se aplicou cal cário ao solo esteve em cerca de 70\% da máxima alcançada no ní vel 3 de calagem ( pH final $=5,8$ e alumínio, trocável nulo no solo).

A porcentagem de nitrogēnio na parte aērea da ga lactia, no primeiro corte (Tabela 15), sofreu incrementos posi tivos mediante a aplicação do calcārio até a dose 2, a partir do qual decresceu, resultando num efeito quadrático da calagem (Tabela 19). MIRANDA (1979) tambēm obteve aumentos nessa variā vel quando adicionou calagem e cálcio a um solo Podzólico. os valores absolutos encontrados para o teor de nitrogênio na galactia, no primeiro corte e na presença dos dois níveis mais 
altos de calagem (teores de 2,15 e $2,13 \%$ de nitrogēnio) são su periores ao teor de $1,89 \%$ apontado por MIRANDA (1979), no solo Podzólico Vermelho Amarelo, como indicador de adequado estado nutricional. Isso equivale a dizer que jă no primeiro corte a fixação de nitrogēnio estava operando de forma ativa, pois não se aplicou qualquer forma de nitrogēnio combinado à legumi nosa.

Pelos dados obtidos no segundo corte da galactia e apresentados na Tabela 16 verifica-se que a calagem influiu na produção de matéria seca, no nitrogénio total e na nodulação dessa leguminosa, atravēs de aumentos nessas variāiveis à medida que se elevou a dose de calagem, exceto para a dose 2 (1,66 toneladas por hectare). Com efeito, nessa dose 2 de cala gem essas variāveis tiveram valores absolutos menores que no nivel 1 , o que resultou em alta significância para a regressão cübica para a calagem (Tabela 20).

A produção de matēria seca da parte aērea, na a sência de calagem, representou cerca de $65 \%$ do mäximo alcançado com a maior dose de calcário aplicada, o que de certa forma confirma as apreciações de MATTOS e ALCÂNTARA (1976) sobre a tolerāncia à acidez dessa leguminosa.

A porcentagem de nitrogēnio na parte aērea da ga lactia (Tabelas 16 e 20), do nivel 0 ao 2 de calagem, mostrou redução no seu valor; no entanto voltou a aumentar, atingindo o máximo no nível 3 de calcärio (2,49 toneladas por hectare). o teor de nitrogēnio constatado em qualquer dos níveis de cala 
gem, está acima do valor $1,89 \%$ verificado com essa leguminosa cultivada em adubação completa por MIRANDA (1979).

Tabela 15. Produção de matéria seca, porcentagem de nitrogēnio e nitrogénio total na parte aérea no lo corte da ga lactia (com 54 dias), em função dos nĩveis de calagem. Significância do teste $F^{a}$ para os componentes linear, quadrático e cúbico. Médias de 12 dados ini ciais.

\begin{tabular}{cccc}
\hline $\begin{array}{l}\text { Niveis } \\
\text { de } \\
\text { calagem }\end{array}$ & $\begin{array}{c}\text { M.S. } \\
\text { (g/vaso) }\end{array}$ & $\begin{array}{c}N \\
\%\end{array}$ & $\begin{array}{c}\text { N total } \\
\text { (mg/vaso) }\end{array}$ \\
\hline 0 & 4,56 & 1,80 & 82 \\
1 & 5,45 & 1,94 & 105 \\
2 & 5,69 & 2,15 & 122 \\
3 & 6,38 & 2,13 & 136 \\
Reg.linear & $* \star$ & $\star \star$ & $\star \star$ \\
Reg.quadr. & $n s$ & $*$ & $n s$ \\
Reg.cübica & $n s$ & $n s$ & $n s$ \\
\hline
\end{tabular}

a. * e ** = significâncias aos níveis de $5 \%$ e $1 \%$ de probabilidade, respectivamente. $n s=$ não significativo

O teor de nitrogénio nas raízes da leguminosa mostrou tendéncia exatamente inversa ao da parte aérea (Tabe las 16 e 20). Com outras leguminosas, também se tem verificado 


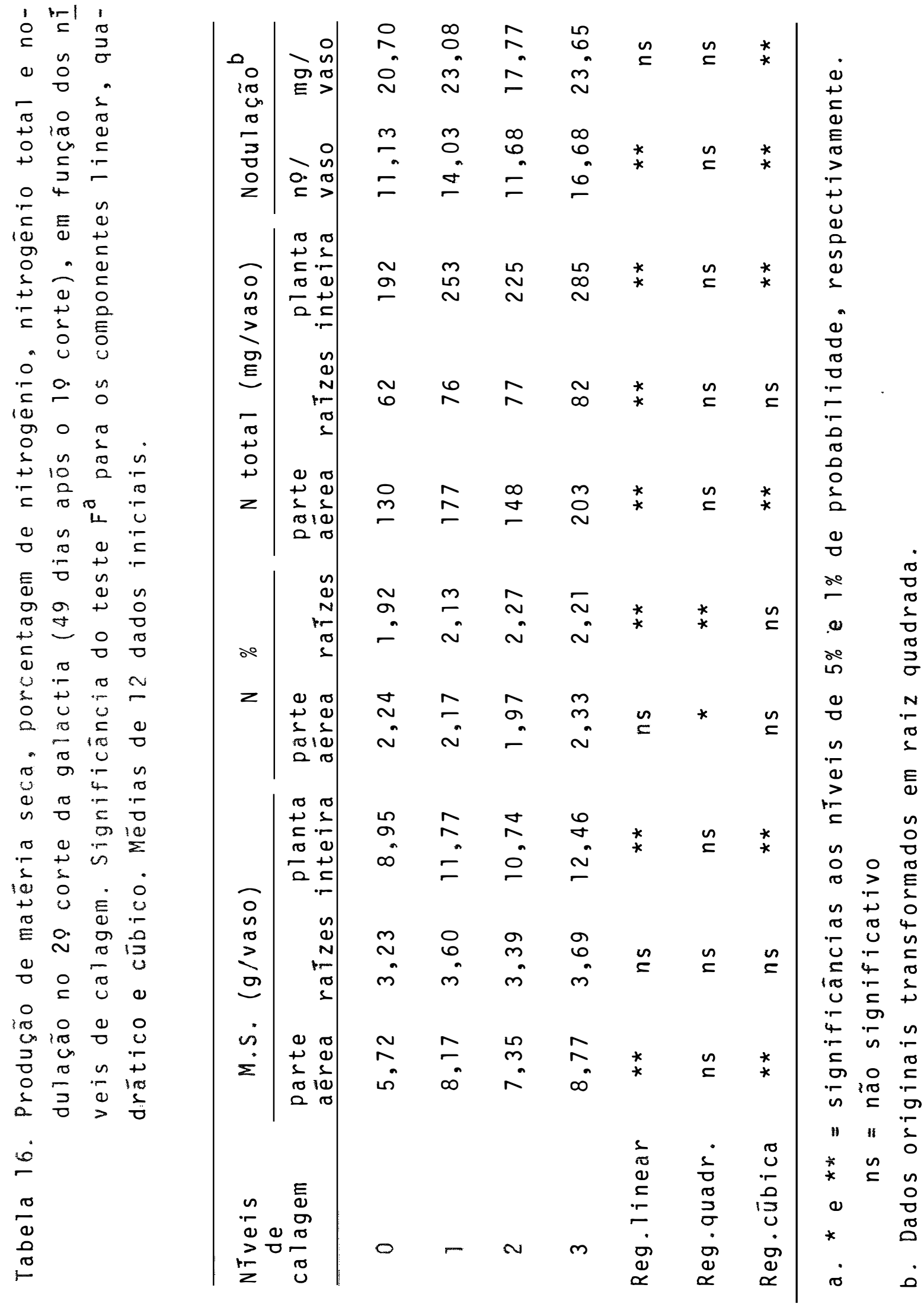


- aumento da porcentagem desse elemento nas raizes com a aplicação de calcārio, como é o caso de WERNER e MATTOS (1972), cuI tivando a centrosema.

Quanto à nodulação da galactia, na ausēncia de calagem (pH final $=4,9)$, o peso total dos nódulos representou cerca de $77 \%$ do total alcançado no máximo nível de calagem estudado (pH final $=5,8$ ) revelando essa leguminosa boa capacida de em nodular, mesmo nas condições de maior acidez do meio.

Os teores de fósforo na parte aérea da galactia, tanto no primeiro como no segundo corte (Tabelas 17 e 18), mos tram que, à exceção dos valores obtidos para o nível o de cala gem, os demais teores do elemento crescem à medida que se aumenta a dose de calagem. Aumentos nessa variāvel tem sido cons tatados com soja perene (FRANÇA et alii, 1973), com centrosema (WERNER e MATTOS, 1972) e com siratro (MATTOS, 1972), mediante o emprego de calagem. Quanto ao teor relativamente alto ocorri do no nível 0 de calagem, especialmente no primeiro corte, MIRANDA (1979) também verificou teor de fósforo significativamen te mais elevado na galactia, na omissão de calagem mais cálcio em um solo Podzólico Vermelho Amarelo. Esse mais alto teor de fósforo coincide com o menor crescimento da planta, o que torna possivel a ocorrência de um efeito de diluição do elemento no interior da planta com maior desenvolvimento.

os teores de cálcio na galactia, no material coIhido no primeiro e no segundo corte (Tabelas 17 e 18), aumentaram significativamente à medida que se elevou a aplicação de 
rol El u

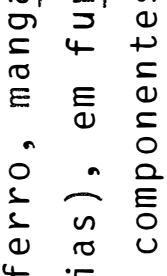

4 .r

a 00

$\begin{array}{lll}1 & 0 & 0 \\ 1 & 0 & 0\end{array}$

○

$\begin{array}{llll}0 & 0 & 0 & 0 \\ & 0 & 0\end{array}$

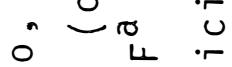

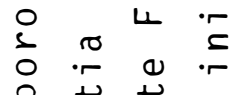

u un us

م 000

.

i 0100

iro 0 o 0

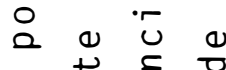

. + $\frac{1}{10}$

0004

$\begin{array}{llll}1 & 0 & 0 & 0\end{array}$

10 $0.5 \frac{1}{5}$

o) on $\Sigma$

잉

a 0.0

$\begin{array}{cccc}0 & 0 & E & 0 \\ 0 & 1 & 0 & 0 \\ 0 & 0 & 10\end{array}$

- 0 ठ

1000

๖ 5

$\begin{array}{llll}0 & 0 & 0 & 0 \\ 0 & 0 & 0 & 1\end{array}$

4 a n iro

$\begin{array}{cccc}n & 5 & 1 & 1 \\ 10 & 0 & 0 & 0\end{array}$

(1) U

O

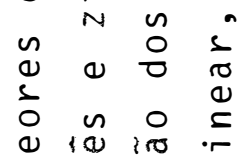

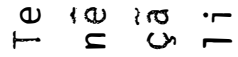

$\sim$
0
0
0
0
0

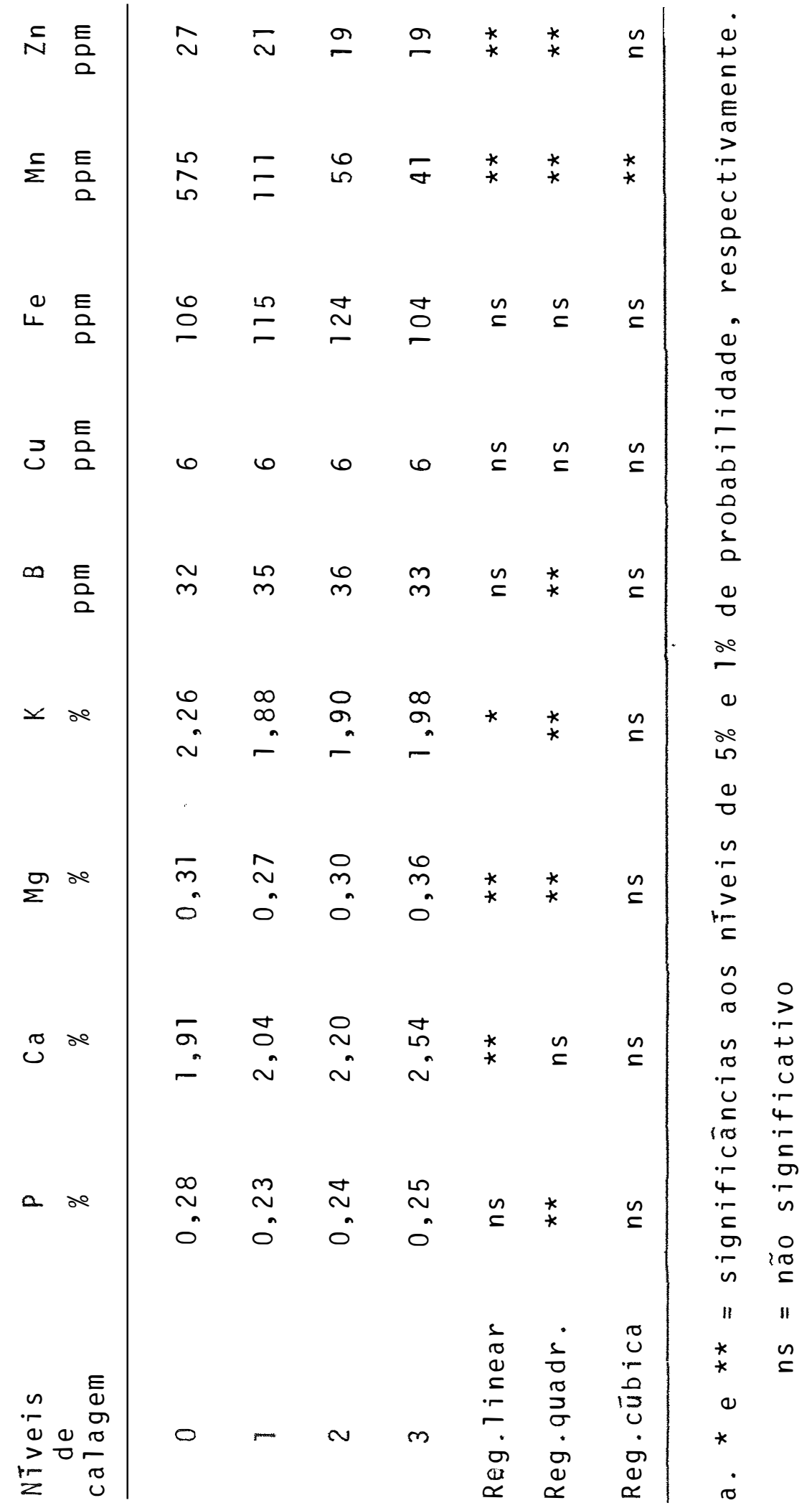




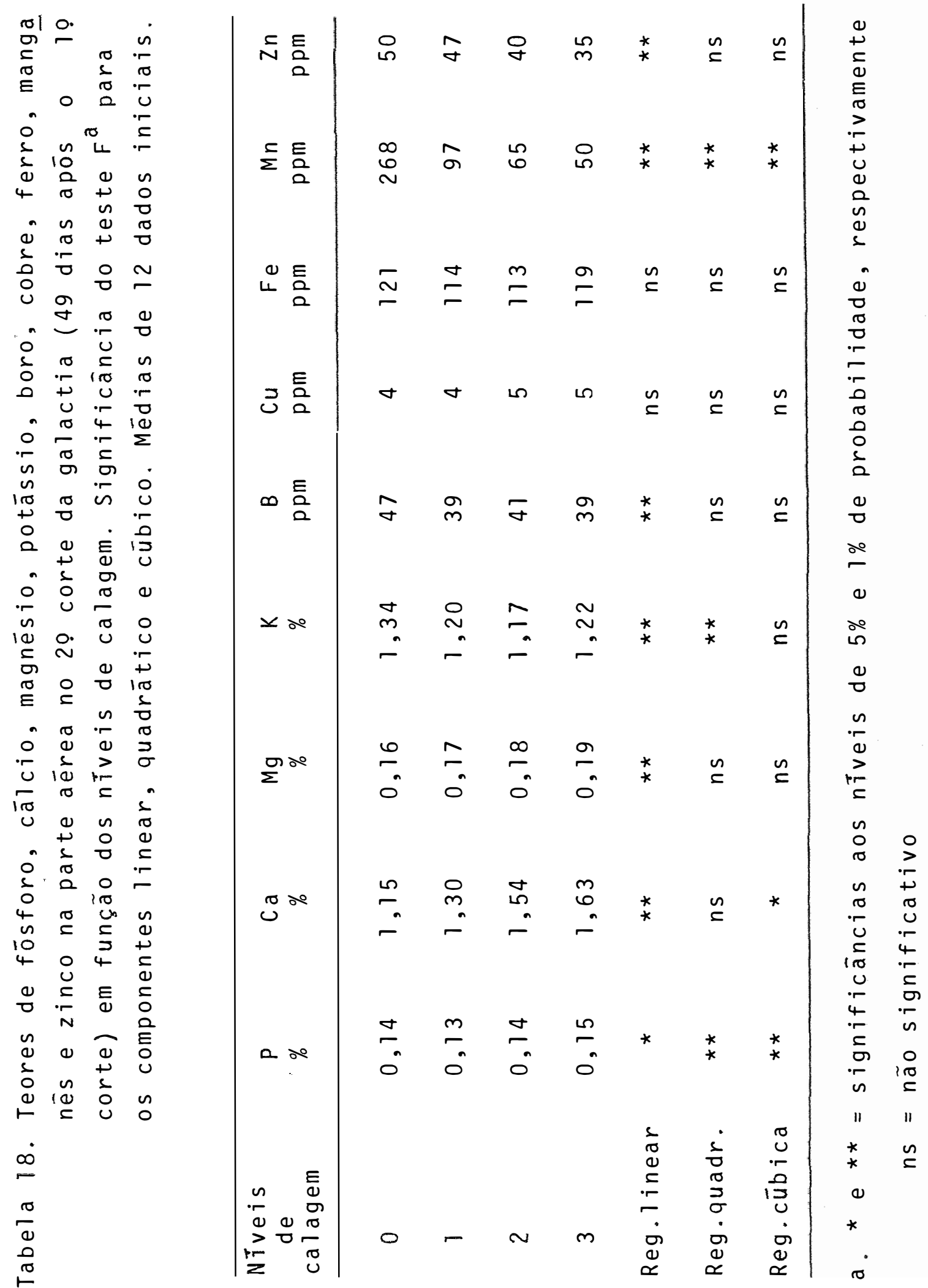


calcārio ao solo. Também, as porcentagens de magnésio em ambos os cortes e exceto para o nível zero de calagem no segundo cor te, sofreram acréscimos significativos com a calagem. 0 teor de magnésio encontrado na ausência de calagem no primeiro corte, inexplicavelmente estā acima daquele verificado nos níveis 1 e 2 de calcário, no mesmo corte. Aumentos nos teores de ambos macronutrientes, em decorrēncia da calagem, são relatados na literatura, para outras leguminosas forrageiras (JONES e FREITAS, 1970; MATTOS, 1972, FRANÇA et alii, 1973).

Tabela 19. Equações de regressão obtidas entre as variāveis estudadas na galactia e os niveis de calagem testados $(0$ a $2,49 \mathrm{t} / \mathrm{ha})$. Dados referentes ao primeiro corte da espécie.

Variāvel estudada Equação de regressão

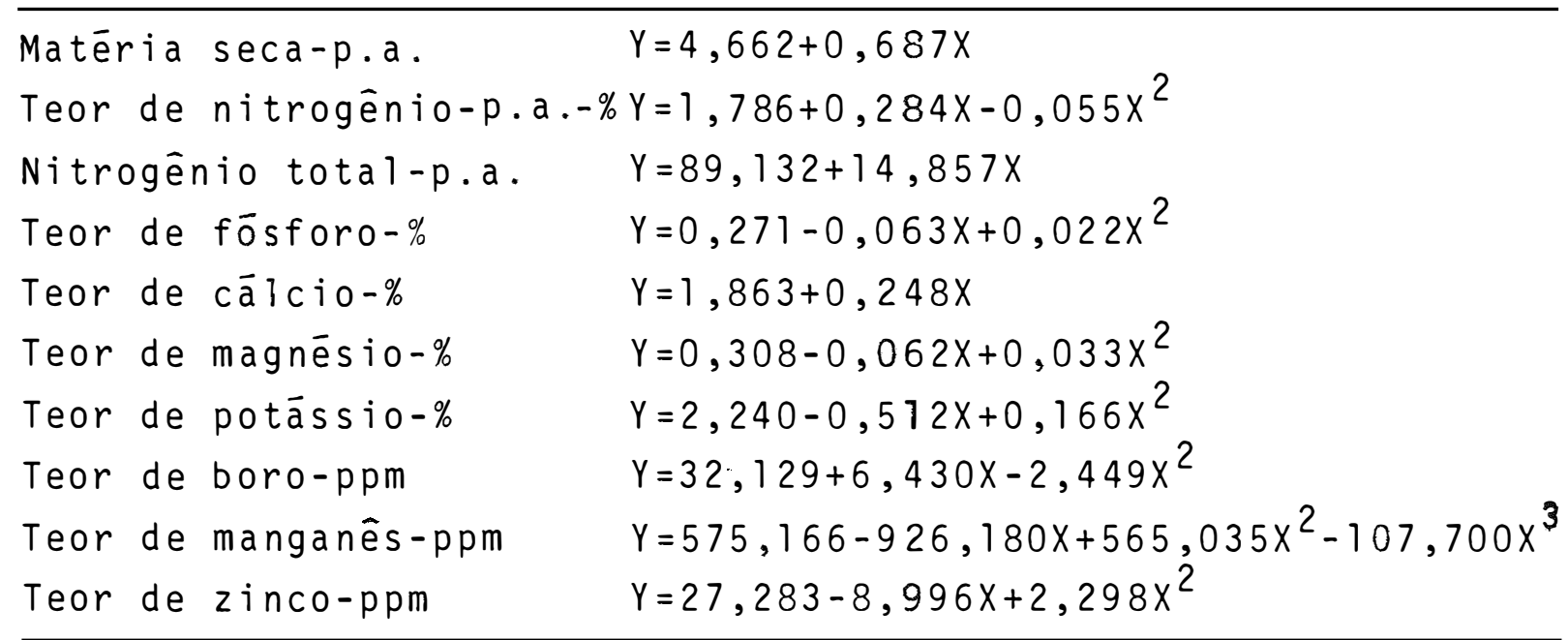

a. Y é o valor para a variāvel estudada enquanto X é a dose de calcário empregada, dentro dos limites testados. 
Tabela 20. Equações de regressãoa obtidas entre as variáveis es tudadas na galactia e os niveis de calagem testados (0 a $2,49 t / h a)$. Dados referentes ao segundo corte da espēcie.

Variàvel estudada

Equação de regressão

\begin{tabular}{|c|c|}
\hline Matēria seca-p.a. & $Y=5,720+7,054 x-6,371 x^{2}+1,607 x^{3}$ \\
\hline Matēria seca-pl.int. & $Y=8,954+8,265 x-7,573 x^{2}+1,922 x^{3}$ \\
\hline Teor de nitrogēnio-p.a.-\% & $Y=2,279-0,379 x+0,154 x^{2}$ \\
\hline Teor de nitrogênio-raiz-\% & $Y=1,915+0,360 x-0,095 x^{2}$ \\
\hline Nitrogênio total-p.a. & $Y=129,500+169,338 x-172,800 x^{2}+46,953 x^{3}$ \\
\hline Nitrogēnio total-raiz & $Y=65,400+7,208 x$ \\
\hline Nitrogēnio total-pl.int. & $Y=191,500+201,173 x-195,179 x^{2}+51,956 x^{3}$ \\
\hline Nodulação $o^{b}-n o ̣ / v a s o$ & $Y=11,151+11,038 x-12,113 x^{2}+3,470 x^{3}$ \\
\hline Nodulação $o^{b}-m g / v a s o$ & $Y=20,704+15,350 x-19,295 x^{2}+5,506 x^{3}$ \\
\hline Teor de fósforo-\% & $Y=0,144-0,055 X+0,056 X^{2}-0,013 x^{3}$ \\
\hline Teor de cálcio-\% & $Y=1,147+0,023 x 00,238 x^{2}-0,068 x^{3}$ \\
\hline Teor de magnésio-\% & $Y=0,164+0,009 x$ \\
\hline Teor de potássio-\% & $Y=1,335-0,216 x+0,069 x^{2}$ \\
\hline Teor de boro-ppm & $Y=44,841-2,650 X$ \\
\hline Teor de manganês-ppm & $Y=268,250-326,999 x+189,494 x^{2}-35,633 x^{3}$ \\
\hline Teor de zinco-ppm & $Y=51,008-6,516 X$ \\
\hline
\end{tabular}

a. Y $\bar{e}$ o valor para a variāvel estudada enquanto $x \bar{e}$ a dose de calcário aplicada, dentro dos limites estudados.

b. Dados transformados em raiz quadrada. 
Com o emprego dos níveis de calagem, os teores de potássio na galactia, tanto no primeiro como no segundo cor te (Tabelas 17 e 18) revelaram um nitido comportamento quadrātico (Tabelas 19 e 20). As mais altas porcentagens desse elemento estiveram nos níveis 0 e 3 de calagem, mas quando se com para ambas nota-se que há tendēncia de redução do teor de potássio, na calagem mais alta. Essa queda nos teores de potás sio com a calagem, é verificada nos niveis intermediārios de calagem e tem sido citada em trabalhos envolvendo leguminosas forrageiras (JONES e FREITAS, 1970). 0 acréscimo no teor de po tássio na presença da maior dose de calcārio, em relação às in termediārias, mostra resultado semelhante ao verificado por MI RANDA (1979) quando efetuou a calagem num solo Podzölico culti vado com siratro.

A concentração de boro na parte aērea dessa legu minosa, no primeiro corte (Tabela 17), mostrou acréscimos com as primeiras doses de calcário e uma queda no seu teor na presença do mais alto nível de calagem, o que resultou em efeito quadrático da callagem (Tabela 19). Jā no segundo corte, o teor desse micronutriente evidenciou um decréscimo linear à medida que se aumentou a calagem (Tabela 20), o que tambēm foi obtido por MIRANDA (1979).

os teores de cobre e ferro não revelaram qualquer variação na galactia, em ambos os cortes, com o emprego das doses de calcārio dolomitico.

A medida que se acrescentou a calagem ao solo,os 
teores de manganēs e zinco decresceram nessa leguminosa, sendo isso observado nos dois cortes realizados no experimento. Redu ções nesses teores com a aplicação de calcārio são relatados em galactia por MIRANDA (1979) e em outras leguminosas por DÖBEREINER E ARONOVICH (1966), MATTOS (1972) e WERNER E MATTOS $(1972)$

Com relação ao teor de manganēs na galactia, em auséncia de calagem e no primeiro corte, o mesmo esteve em 575 ppm. MIRANDA (1979) obteve valores entre 600 e 700 ppm na parte aērea da galactia, quando omitia a calagem ou a calagem e cálcio. No presente experimento, não se evidenciaram sintomas visuais de toxidez de manganés nessa leguminosa, mas a correla ção entre os teores desse micronutriente com a produção de matéria seca da parte aérea (dados do segundo corte do ensaio) foi negativa e significativa $\left(r=-0,66^{* *}\right)$. Enquanto isso, não se constatou correlação linear entre os teores de manganês e o peso de nōdulos na galactia, permitindo supor que a nodulação seria menos afetada pelo excesso de manganēs do que a produção de matéria seca, nessa espécie. A Figura 6 ilustra o comportamento dessas trés variáveis, em função da calagem testada.

Baseando-se na variāvel nitrogênio total e cons 1 derando-se as equações de regressão obtidas para essa variável, em função dos nĩveis de calagem (Tabelas 19 e 20), pode-se observar que o máximo vaìor do nitrogênio total no primeiro corte, ocorreria numa dose além da estudada. Entretanto, o nitrogénio total da planta inteira, no segundo corte, teria o seu 
valor māximo mediante o emprego de 0,72 toneladas de calcārio por hectare. Através da Figura 1 , pode-se verificar que essa calagem proporcionaria, por ocasião do plantio, os seguintes valores na anālise química do solo estudado: $\mathrm{pH}=5,05, \mathrm{Al}^{3+}=$ $0,45,\left(\mathrm{Ca}^{2+}+\mathrm{Mg}^{2+}\right)=0,86, \mathrm{~V}=23,2 \%$ e $\mathrm{m}=33,2 \%$.

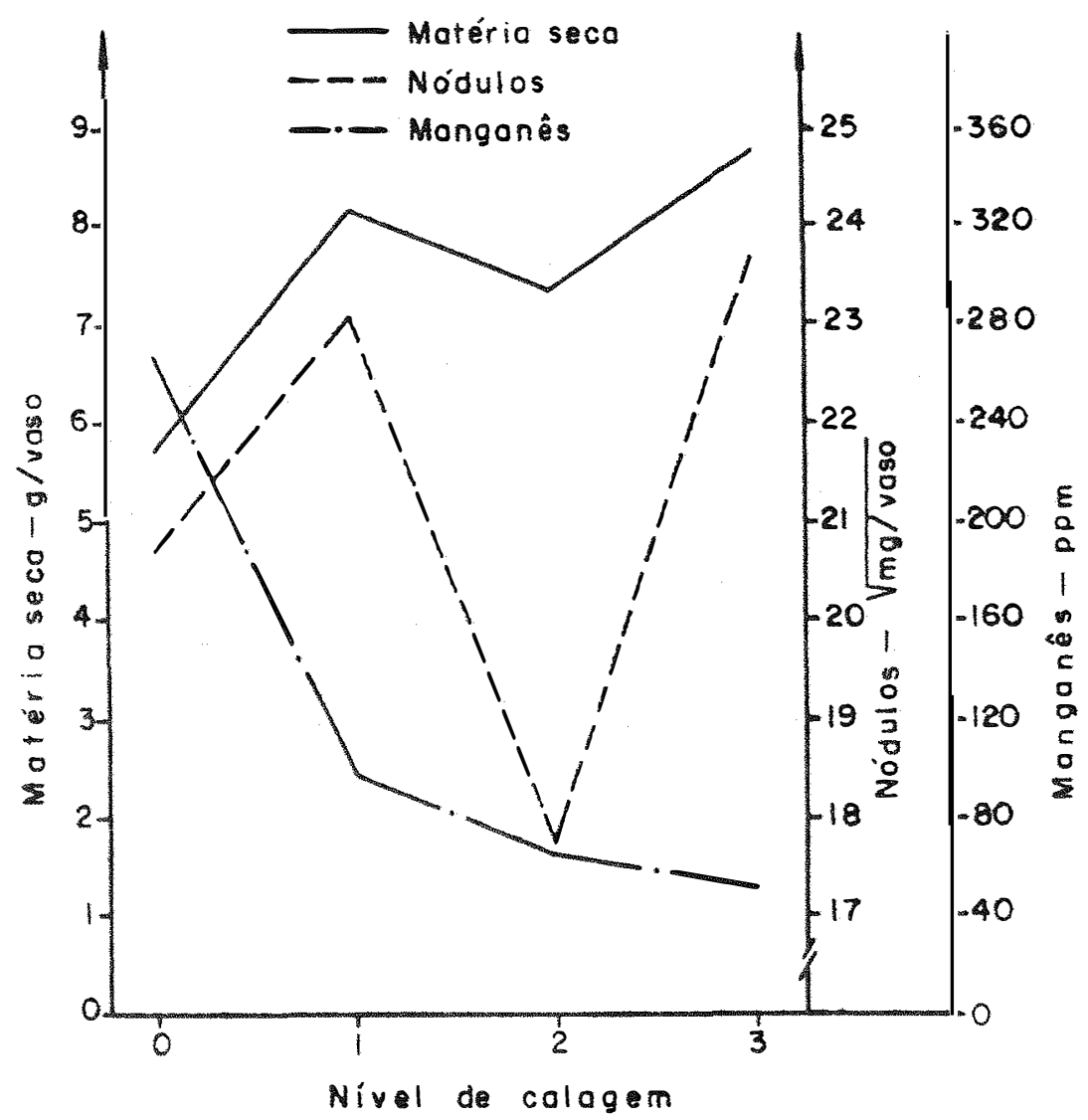

Fig. 6. Relação entre os teores de manganês na parte aërea e peso de nōdulos e produção de matéria seca da galactia, obtidos no 20 corte do ensaio. 
4.3. Efeitos dos micronutrientes nas leguminosas.

Dada a importāncia que as condições de acidez do meio tem na disponibilidade dos micronutrientes e à consequente resposta das plantas à aplicação dos referidos elementos, tratar-se-á no presente trabalho de estudar os efeitos dos mes mos nas quatro leguminosas forrageiras, dentro de cada nivel de calagem testado.

4.3.1. Soja perene var. Tinaroo

As significâncias (teste F) para os tratamentos dos micronutrientes aplicados dentro de cada nível de calagem, no cultivo da soja perene Tinaroo, são apresentadas nas Tabe las 21 e 22 .

As anālises dos dados obtidos no primeiro corte dessa leguminosa forrageira (Tabela 2l) revelam que a produção de matēria seca da parte aērea foi significativamente aumentada pela aplicação do molibdënio, na presença do nível 2 de calagem $(\mathrm{pH}$ inicial $=5,4$ e final $=5, E)$. O desdobramento das in terações (Mo X $B+C u+Z n)$, dentro dos níveis 1 (pH inicial = $5,1), 2(p H$ inicial $=5,4)$ e 3 de calagem $(p H$ inicial =5,6), revelou que nos três casos a aplicação do molibdênio em ausência de boro + cobre + zinco, teve efeito significativo e positivo na produção de matéria seca. Resultados favorāveis da aplicação do molibdēnio, para essa variável da soja perene, são relatados por Quagliato e Jones, citados por QUAGLIATO (1966)e por WERNER E MATTOS (1974). 
o teor de nitrogēnio na parte aērea obtida no primeiro corte da soja perene (Tabela 2l) sofreu o efeito sig nificativo e negativo da aplicação do molibdénio ou do emprego do molibdēnio em presença de boro + cobre + zinco, somente dentro do nível 0 de calagem ( $p H$ inicial $=4,7)$.

o nitrogénio total na soja perene, à época do primeiro corte (Tabela 27 ) foi significativamente aumentado pelo molibdénio simplesmente ou pelo molibdênio na auséncia dos outros trés micronutrientes, dentro dos dois mais altos niveis de calagem.

A produção de matéria seca da parte aērea no se gundo corte da soja perene (Tabela 22) foi significativamente aumentada, dentro das doses $1(\mathrm{pH}$ final $=5,4), 2(p H$ final $=$ $5,6)$ ou 3 de calcārio ( pH final =5,9), pela aplicação do molibdénio. Ainda, esse micronutriente em auséncia de boro + co bre + zinco mostrou semelhante efeito positivo, dentro do n $\vec{i}-$ vel 2 de calagem. O emprego conjunto do boro, cobre e zinco, na presença de 2,49 toneladas de calcārio por hectare (cala. gem 3) resultou em efeito negativo nessa variável.

Enquanto a produção das raỉzes não sofreu alteração pelo emprego dos micronutrientes (Tabela 22), a produ ção de matéria seca da planta inteira teve efeitos significativos da presença do molibdēnio, junto aos nîveis 1, 2 ou 3 de calagem. Semelhantes resultados com soja perene foram obti dOS por WERNER e MATTOS (1974). 
Tabela 21. Significáncias do teste $F^{a}$ para o fatorial dos micronutrientes aplicados, dentro de cada nivel de ca lagem, para a soja perene. Dados referentes à parte aérea obtida no primeiro corte da espécie.

\begin{tabular}{|c|c|c|c|c|c|c|c|c|c|c|c|}
\hline \multirow{2}{*}{$\begin{array}{l}\text { Variāvel } \\
\text { estudada }\end{array}$} & \multicolumn{2}{|c|}{ Calagem 0} & \multicolumn{3}{|c|}{ Calagem $T$} & \multicolumn{3}{|c|}{ Calagem 2} & \multicolumn{3}{|c|}{ Calagem 3} \\
\hline & Mo $c^{b}$ & MoxC & Mo & C & $M \circ \times C$ & Mo & C & MoxC & Mo & C & MoxC \\
\hline Matēria seca & & & & & * & $\star \star P$ & & $\star \star$ & & & * \\
\hline Teor de $\mathrm{N}-\%$ & $\star n$ & $\star \star$ & & & & & & & & & \\
\hline$N$ total & & & & & & $\star \star P$ & & $\star \star$ & $\star \star \mathrm{P}$ & & * \\
\hline Teor de B-ppm & $\star \star$ & & & $\star \star$ & & & $\star \star$ & & & $\star \star$ & \\
\hline Teor de Cu-ppm & & & & & & & & & & & \\
\hline Teor de Zn-ppm & & & & & & & & & & & \\
\hline
\end{tabular}

a. $\left(^{*}\right)$ e $\left({ }^{*}\right)=$ significâncias aos niveis de 5 e $1 \%$ de probabi lidade, respectivamente.

b. O símbolo C representa a aplicação conjunta de B + Cu + Zn p e $n=$ efeitos positivos e negativos, respectivamente.

o molibdênio proporcionou aumentos significativos na porcentagem de nitrogēnio na parte aérea da soja perene, no segundo corte, quando empregado dentro de calagem 0,1 ou 2 (Tabela 22). Dentro do nível 0 de calagem, em presença de boro + cobre + zinco, o efeito daquele micronutriente foi favorä vei ao teor de nitrogénio tanto da parte aérea como das raízes. Aliās, o porcentual de nitrogênio nas raizes foi significativa mente aumentado pela aplicação de molibdênio, junto aos nĩveis 


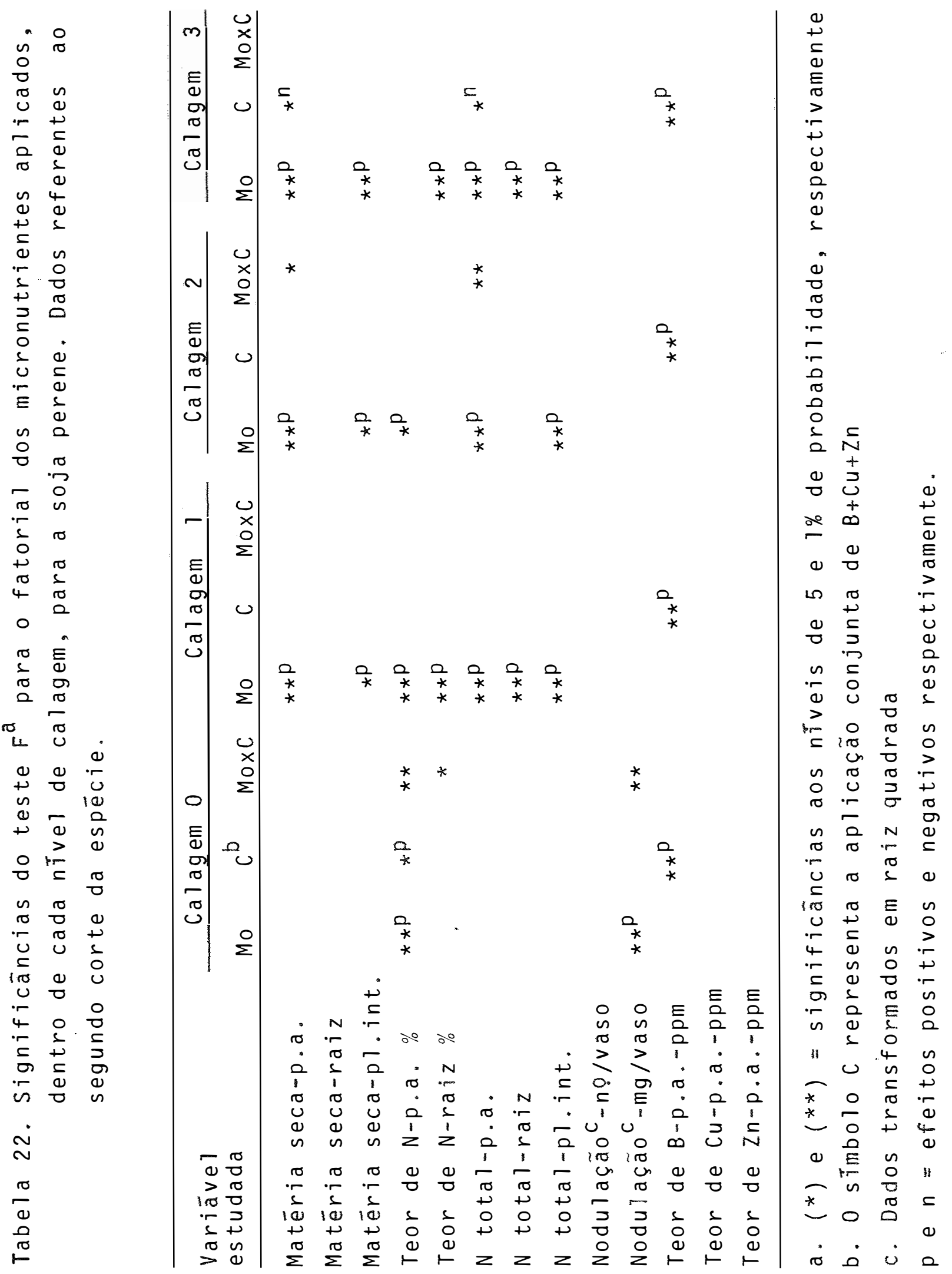


1 e 3 de calagem. Aumentos nessas variāveis. como resultante da aplicação do molibdēnio são referidas por FRANÇA et alii (1973) e WERNER e MATTOS (1974).

0 emprego de boro, cobre e zinco juntos resultou em elevação significativa na porcentagem de nitrogênio na par te aérea, quando em ausēncia de calagem (Tabela 22).

0 nitrogénio total na parte aérea e na planta inteira dessa leguminosa, no segundo corte (Tabela 22), foi significativamente aumentado em decorrência da presença do molibdēnio junto aos níveis 1, 2 ou 3 de calagem. Ainda, esse micronutriente em calagem 2 e na ausēncia de boro + cobre + zinco teve efeito benéfico no nitrogênio total da parte aérea. Também o nitrogēnio total nas raízes (Tabela 22) foi incremen tado pela aplicação do molibdênio, junto aos níveis 1 e 3 de calagem. Aumentos expressivos nessas variāveis de soja perene, pelo emprego desse micronutriente são relatados por FRANÇA et alii (1973), TRIGOSO e FASSBENDER (1973) e WERNER e MATTOS (1974) e concordam com as afirmações de HALLSWORTH (1958), AN DREW (1962) e EPSTEIN (1975) sobre o papel desse micronutrien te na eficiência da fixação de nitrogēnio pela leguminosa.

A aplicação de boro + cobre + zinco, em presença do nível 3 de calagem, proporcionou resultado depressivo e significativo no nitrogènio total da parte aérea, relativa ao segundo corte da espécie (Tabela 22).

o número de nödulos da soja perene (Tabela 22)

não foi alterado pelo emprego de qualquer tratamento envolven- 
do micronutrientes. Já o peso dos nódulos secos, foi significa tivamente aumentado pelo molibdênio simplesmente ou pelo molib dēnio na presença de boro + cobre + zinco, no nível o de calagem (Tabela 22). Aumentos similares foram constatados em soja perene, por WERNER e MATTOS (1974). O que se pode notar na Tabela 22 é que o molibdēnio aumentou, simultāneamente, 0 peso dos nódulos e o teor de nitrogénio na parte aérea da leguminosa, quando em ausência de calagem. Na presença de calagem somente a porcentagem de nitrogénio foi incrementada pelo molibdēnio evidenciando que esse micronutriente em auséncia de cala gem, aumentou o teor daquele macronutriente através de aumento na massa nodular, enquanto na presença de calagem a elevação naquele teor teria ocorrido devido à maior eficiència da fixação de nitrogènio, na presença do molibdēnio.

observando-se o comportamento dos teores de boro, cobre e zinco na parte aérea da soja perene, em ambos os cortes (Tabelas 21 e 22 ), verifica-se que somente as concentrações de boro na planta foram significativamente aumentadas, em todos os níveis de calagem, pela aplicação desse micronutriente ao solo (juntamente com cobre e zinco). Elevações no teor de boro dessa espécie, mediante aplicação do elemento ao solo, são relatados por MIRANDA (1979).

0 que se verifica, de um modo geral, para a soja perene ē um efeito expressivo do molibdēnio quando empregado na presença de calagem. A não constatação das respostas a esse micronutriente quando não se aplicou calcário ao solo permite supor que, nas condições ācidas (pH inicial = 4,7) o molibdé - 
nio teria sido adsorvido às partículas do solo (KAMPRATH, 1972 e SIQUEIRA e VELOSO, 1978) ou uma relativamente alta disponibilidade de manganés no solo (conforme discutido em 5.2.1.) te ria influenciado para não resposta ao molibdēnio (TRUONG et alii, 1971).

WERNER (1975) aponta que em presença de cala gens baixas e moderadas, apenas a aplicação do molibdēnio se ria necessāria para o cultivo de leguminosas tropicais. Cons derando que as doses empregadas no presente trabalho, para a soja perene, podem ser encaixadas dentro daquelas categorias, os resultados obtidos concordam plenamente com a afirmação do autor citado.

Na Figura 7 são mostradas as variações relati vas ocorridas na produção de matēria seca e no nitrogēnio total da planta inteira bem como no peso de nödulos da soja perene, em função da presença ou não do molibdênio, dentro de cada nỉvel de calagem. Além do já discutido efeito da calagem sobre essas variāveis (que também pode ser atribuído a alguma liberação de molibdênio adsorvido ao solo), fica bem evidente o efeito do micronutriente abordado (especialmente na produ ção de matéria seca e no nitrogênio total), quando em presença de calagem. Pode-se também observar que a magnitude do efeito do molibdénio é maior nos níveis mais elevados de cala gem . 

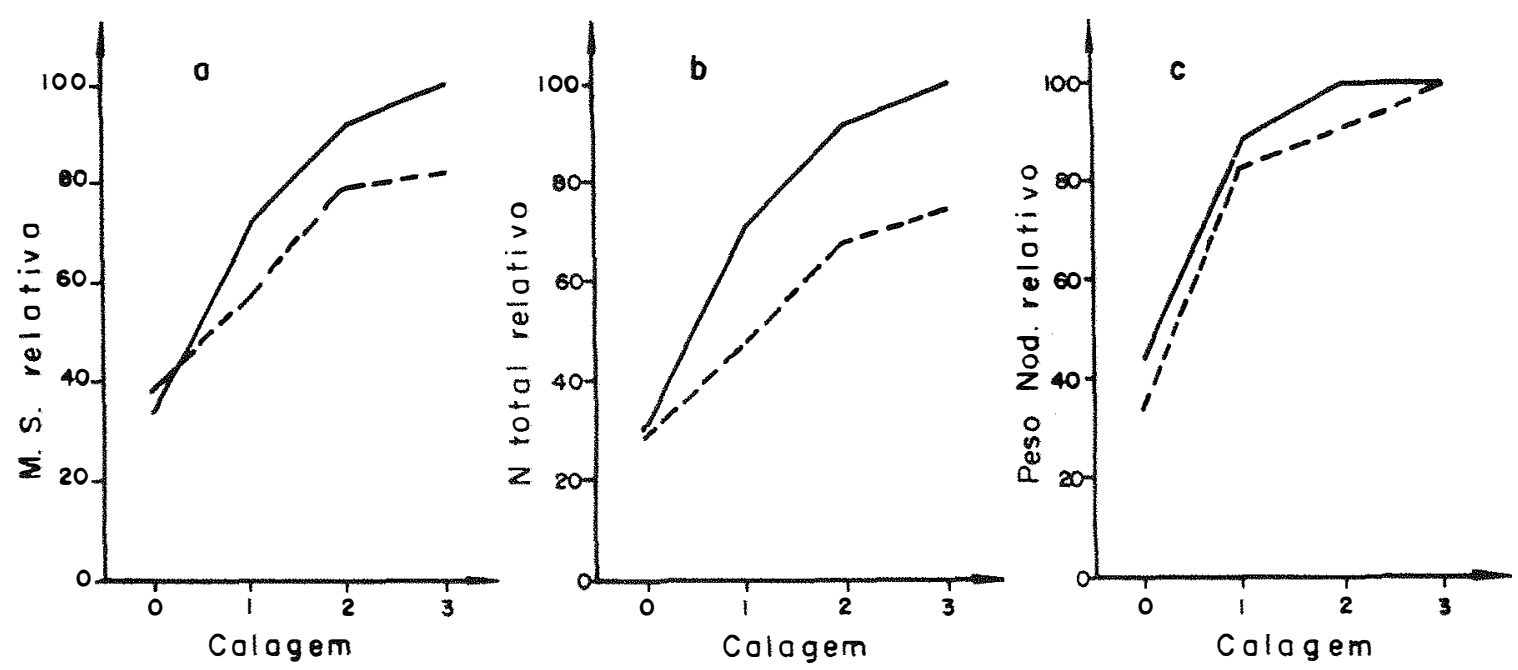

Fig. 7. Variações relativas na produção total de matéria seca (a), no nitrogénio total (b) e no peso de nódulos (c), obtidos no segundo corte da soja perene, mediante os níveis de calagem, sem (-.-) ou com (-) a adição de molibdênio.

\subsubsection{Centrosema}

Na Tabela 23 são mostradas as significāncias ob tidas para o teste $F$ a que foram submetidas as variāveis estú dadas na centrosema, com a aplicação dos micronutrientes, den tro de cada nivel de calagem.

Para os dados de produção de matéria seca, porcentagem de nitrogênio e nitrogênio total na centrosema (Tabe 1 a 23 ) verifica-se que nas doses de calagem 0 (pH inicial=4,7 e final de 5,0$)$ e 1 ( $p H$ inicial $=5,1$ e final $=5,2$ ) não ocor reu qualquer significància para o efeito dos micronutrientes testados. 


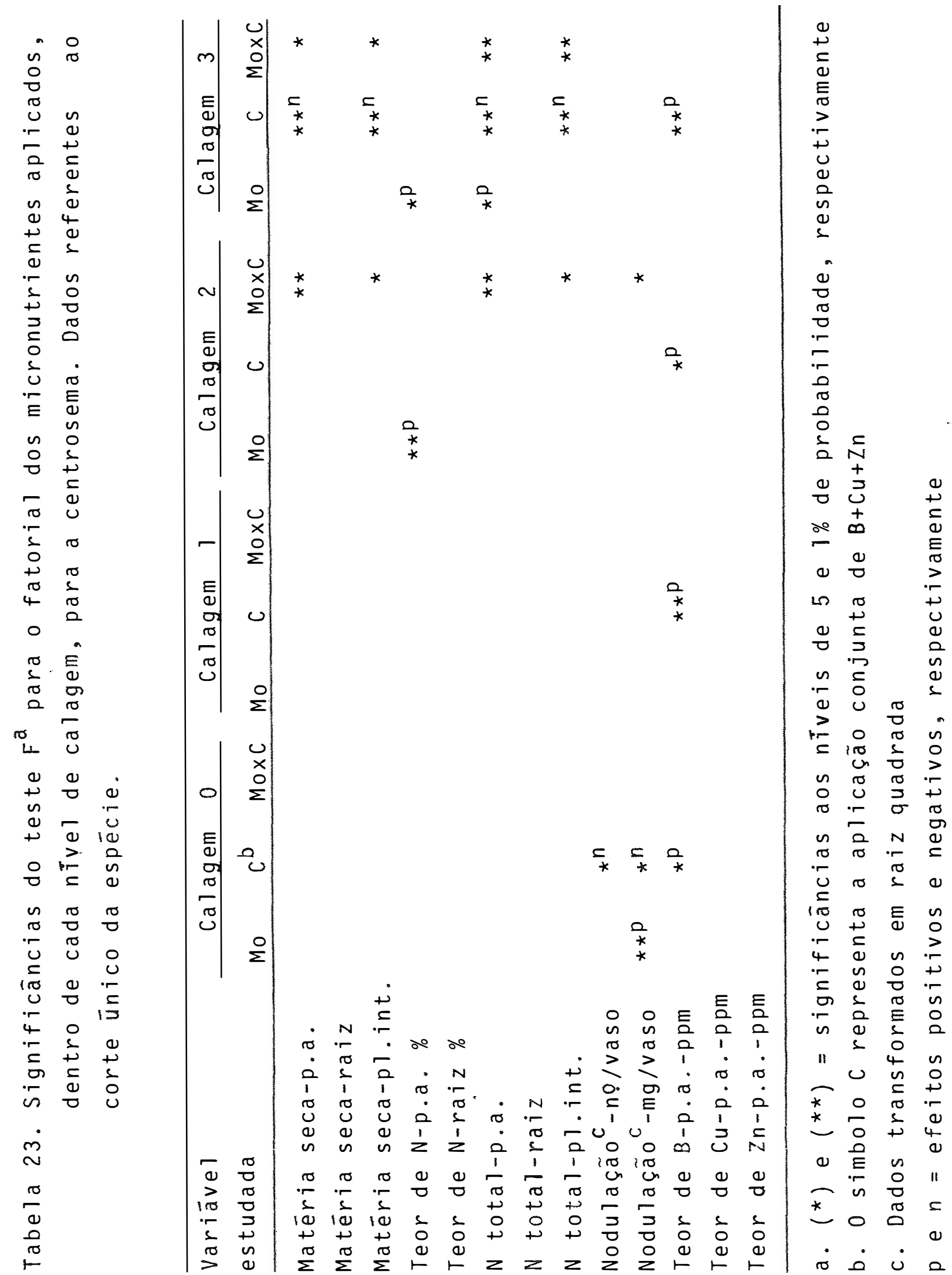


A produção de matéria seca da parte aērea e da planta inteira (Tabela 23) foram significativamente deprimidas pela aplicação de boro + cobre + zinco, em presença do nỉvel 3 de calagem ( $p H$ inicial $=5,6$ e final $=5,7)$. Essas mesmas variāveis tiveram interações significativas para os micronutrien tes, nos niveis 2 e 3 de calagem. 0 desdobramento dessas interações dentro da dose 2 de calcārio (pH inicial $=5,4$ e final $=5,5)$ revelou efeito negativo e significativo para o molibdénio na presença dos outros trés micronutrientes. Dentro da dose 3 , entretanto o efeito do molibdénio na auséncia de boro + cobre + zinco foi significativo e positivo para a produção de matéria seca da planta inteira e esteve próximo da significância para a produção de matéria seca da parte aérea. A presença conjunta de boro, cobre, molibdēnio e zinco em solo com pH 5,8-5,9, também foi constatada ser depressiva para a produção de matéria seca da centrosema, por WERNER e MATTOS (1972).

o teor de nitrogēnio na parte aērea (Tabela 23)

foi significativamente incrementado pelo emprego do molibdénio, dentro dos niveis 2 e 3 de calagem. Semelhantes resultados foram obtidos com centrosema por TEITZEL e BRUCE (1972), WERNER e MATTOS (1975), MONTEIRO et alii (1975), WERNER et alii (7975) e DE-POLLI et alii (1976).

O nitrogēnio total na centrosema (Tabela 23) tan to na parte aërea como na planta inteira foram deprimidos pela aplicação de boro + cobre + zinco, dentro da dose 3 de calagem. Entretanto o emprego do molibdēnio juntamente com o nivel 3 de 
calagem teve efeito positivo no nitrogênio total na parte aérea enquanto o molibdēnio na ausência de boro + cobre + zinco aumen tou significativamente o nitrogēnio total na parte aérea e na planta inteira, quer no nível 2 ou no nível 3 de calagem. Aumen tos semelhantes nessas variāveis, com centrosema são relatados por WERNER e MATTOS (1975), MONTEIRO et alii (1975), WERNER et alii $\left(1975^{b}\right)$ e DE-POLLI et alii (1976).

os dados coletados para as raízes (produção de ma tëria seca, porcentagem de nitrogēnio e nitrogēnio total) não exibiram qualquer variação significativa mediante o emprego dos micronutrientes testados.

A aplicação de boro + cobre + zinco, em ausēncia de calagem ( $p H$ inicial $=4,7$ e final $=5,0)$, deprimiu significa tivamente o número e o peso de nōdulos na centrosema (Tabela 23). Dentro desse mesmo nivel de calagem, o molibdēnio teve efeito positivo no peso de nódulos. Entretanto, esses efeitos não resultaram em qualquer alteração no nitrogēnio fixado nessa leguminosa, pois não se constatou qualquer efeito dos micronutrientes na porcentagem de nitrogēnio ou no nitrogēnio total dessa espēcie, na dose 0 de calagem.

0 desdobramento da interação significativa dentro do nível 2 de calagem, para o peso de nódulos (Tabela 23) evidenciou um efeito significativo e negativo para o molibdénio na presença dos demais micronutrientes testados.

Ao se analisar os teores de boro, cobre e zinco na parte aérea da centrosema, em função do emprego dos micronutrientes, somente se constatou efeitos positivos e significati- 
vos do emprego de boro + cobre + zinco, na concentração de bo ro na planta, em presença de qualquer dos níveis de calagem (Tabela 23).

Fazendo-se um apanhado geral dos resultados obti dos com o emprego dos micronutrientes na centrosema, verificase que efeitos realmente positivos são encontrados mediante a adubação com molibdênio (em geral na ausēncia de boro + cobre+ zinco) dentro dos niveis 2 (1,66 toneladas de calcärio por hec tare) e 3 de calagem $(2,49 t / h a)$.

A Figura 8 evidencia, esses efeitos do molibdé nio na ausência de boro + cobre + zinco, dentro dos níveis mais elevados de calagem, para a produção de matéria seca da planta inteira e o peso de nódulos na centrosema.
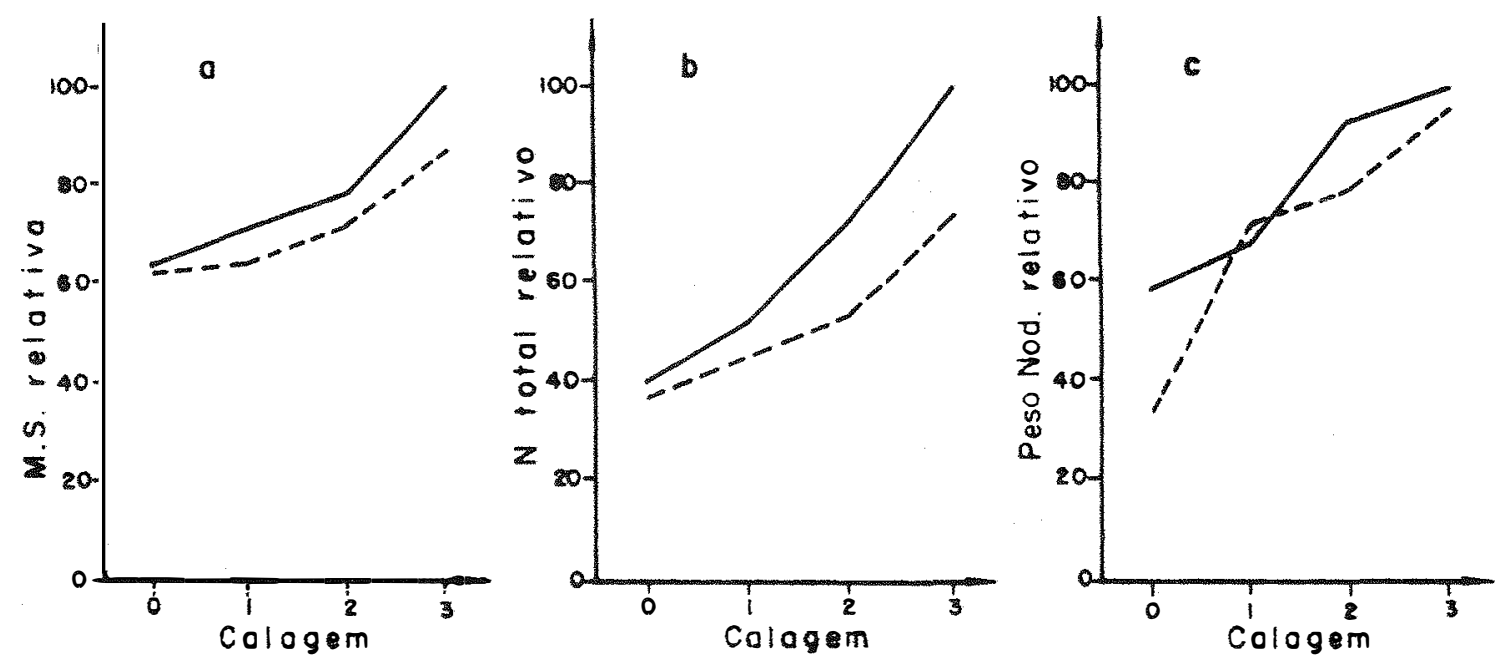

Fig. 8. Variações relativas na produção de matēria seca (a) e no nitrogénio total da planta inteira (b) e na nodula ção (c) da centrosema, mediante os nỉveis de calagem e adição (-) ou não (-.--) de molibdēnio, em ausência de boro + cobre + zinco. 


\subsubsection{Siratro}

AS significâncias verificadas pelo teste $F$ para o emprego dos micronutrientes, dentro de cada nivel de calagem, e nas variāveis estudadas através do cultivo do siratro, são apresentadas na Tabela 24.

Em termos de produção de matēria seca, de porcen tagem de nitrogénio e nitrogēnio total na planta (Tabela 24), não se obteve qualquer efeito para os micronutrientes testados, dentro do nível 0 de calagem $(p H$ inicial $=4,7$ e final $=5,2)$. Ainda dentro do nível 0 de calagem, pode-se notar na Tabela 24 que a aplicação de molibdēnio ou a de boro + cobre + zinco resultou em efeito negativo significativo para o nümero de nödulos nas plantas de siratro. Efeito negativo para o molibdenio sobre o nümero de nōdulos da leguminosa cultivada em pH 5,5 é relatado por DE-POLLI et alii (1976).

Quando se aplicou a dose 1 de calcärio (pH ini cial $=5,1$ e final $=5,4)$, dose esta que proporcionou os sensi veis acréscimos nas variāveis estudadas, observou-se efeitos significativos e positivos da aplicação do molibdénio (Tabela 24) na produção de matéria seca da parte aérea, no teor de nitrogênio (parte aérea e raizes), no nitrogēnio total (parte a ê rea, raizes e pianta inteira) e no peso de nōdulos no siratro. Semelhantes resultados para produção de matēria seca do siratro foram obtidos por TRUONG et alii (1967) e TEITZEL e BRUCE (1973) e para matéria seca e peso de nódulos nessa leguminosa por MATTOS (1972). Aumentos na porcentagem de nitrogênio e no 


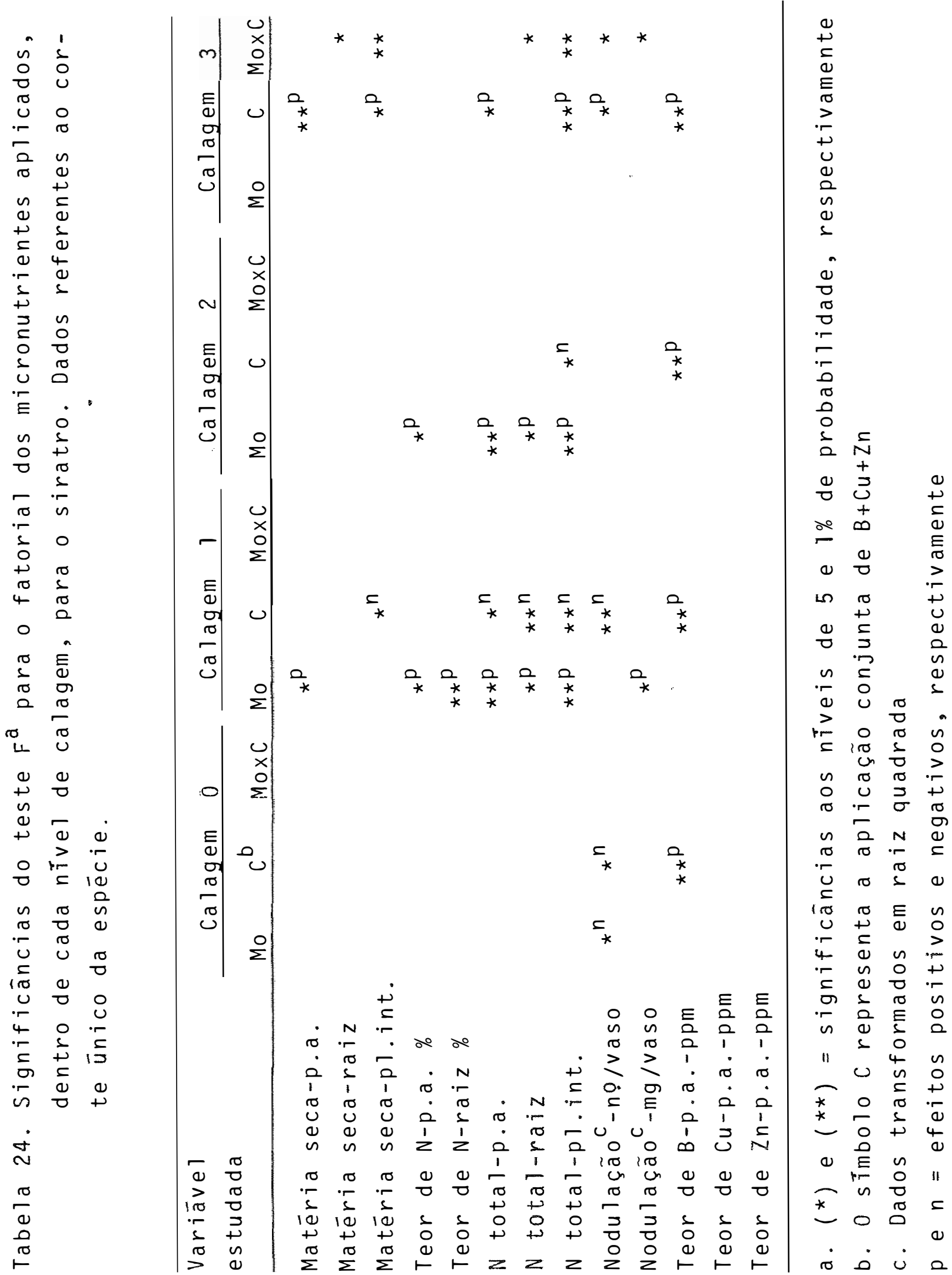


nitrogènio totál pelo emprego do mol ibdēnio em leguminosas foram apresentados por WERNER e MATTOS (1974), MONTEIRO et alii (1975), WERNER et alii $\left(1975^{b}\right)$ e DE-POLLI et alii (1976).

Em presença do nível 1 de calagem $(0,83$ toneladas de calcārio por hectare), o emprego de boro + cobre + zin co mostrou efeito significativo e depressivo (Tabela 24 ) sobre a produção de matéria seca da planta inteira, nitrogénio total (parte aérea, raízes e planta inteira) e número de nōdulos por vaso. Reduções significativas no nitrogênio total, quando se aplicava boro + cobre + zinco para o cultivo de leguminosa forrageira, são relatadas por WERNER e MATTOS (1975).

0 emprego do molibdênio, dentro da dose 2 de cal cärio (pH inicial $=5,4$ e final 5,7) resultou em aumentos significativos no teor de nitrogēnio na parte aérea e no nitrogênio total (parte aérea, raízes e planta inteira). De acordo com o jā discutido, esses aumentos também são relacionados na literatura. Ainda dentro do nível 2 de calagem, a aplicação de boro + cobre + zinco proporcionou significativo decréscimo no nitrogénio total da planta inteira de siratro.

Com relação ao efeito dos micronutrientes dentro do nivel 3 de calagem (pH inicial = 5,6 e final 5,9) pode-se verificar na Tabela 24 que o molibdênio não influenciou em alteração significativa em qualquer das variáveis estudadas. Entretanto o emprego de boro + cobre + zinco resultou em signifi cativos aumentos na produção de matéria seca (parte aērea e planta inteira), no nitrogénio total (parte aérea e planta in- 
teira), bem como no número de nōdulos por vaso. Efeitos positi vos de um ou mais desses nutrientes nas variāveis referidas, foram constatados em siratro, por TRUONG et alii (1967), TEITZEL (1969); TEITZEL e BRUCE (1973), TRIGOSO E FASSBENDER (1973) e FRANCO (1978). Aumento no número de nódulos no siratro, pela aplicação conjunta desses três micronutrientes, em pH elevado, foi obtida por MATTOS (1972).

A aplicação do molibdênio na presença de boro + cobre + zinco resultou em efeitos significativos e depressivos na produção de matēria seca (raízes e planta inteira), nitrogê nio total (raízes e planta inteira) e número e peso de nódulos no siratro. Semelhantes reduções na produção de matéria seca são relatadas por MATTOS (1972) enquanto tal menção para produ ção de matéria seca, nitrogênio total, peso e número de nōdulos é apresentada por WERNER e MATTOS (1972).

Dos resultados mostrados na Tabela 24 e da dicus săo apresentada para o siratro, facilmente se pode depreender que o molibdènio não resultou em efeitos positivos, em presença do nível 0 e do nível 3 de calagem. Enquanto isso o emprego do boro + cobre + zinco somente alterou positivamente algumas variāveis estudadas, na presença do nível 3 de calagem. Esses resultados concordam plenamente com WERNER (1975), admitindo-se que a dose 3 de calcārio seja elevada para o siratro (conforme jā discutido). Para o molibdennio, pode ter ocorrido que na ausência de calagem, mesmo o nutriente aplicado teria se tornado indisponível pela adsorção às partículas do solo (KAMPRATH,1972, 
SIqUEIRA e VELOSO, 1978 e ASHER, 1979). Todavia, à medida que se aplicou calcārio (doses 1 e 2) não teria ocorrido essa fixação e poderia ter havido liberação do adsorvido, o que resultou em efeitos significativos para esse micronutriente, na quelas doses de calagem. Já, em presença do nível 3 de calagem, possivelmente a quantidade de molibdènio liberado do so10 poderia ter sido suficiente para o desenvolvimento do sira tro, naquela dose de calcārio.

Para o boro + cobre + zinco, teria ocorrido uma diminuição na disponibilidade de um ou mais deles, em presença do nível 3 de calagem, a ponto de a aplicação dos mesmos ser necessāria naquela condição. Entretanto, cabe ressaltar que em presença do nível l de calcārio, o emprego desses três micronutrientes resultou em efeitos prejudiciais a s siratro. Nessas condições, além de maior disponibilidade pela aplica ção deles, poderia ter ocorrido um aumento na capacidade de absorção pelas raízes (ASHER, 1979), o que resultou num efeito prejudicial de um ou mais deles para o siratro. Em niveis mais elevados a menor disponibilidade dos micronutrientes citados teria predominado.

A Figura 9 ilustra o que se discutiu para o molibdēnio ou para o boro + cobre + zinco, em função dos nīveis de calagem, para a produção de matēria seca e do nitrogê nio total da planta inteira e da nodulação no siratro.

Em termos de teores dos micronutrientes na parte aērea do siratro nota-se, pela Tabela 24, que somente a concentração de boro foi significativamente aumentada median- 
te o emprego de boro junto ao cobre e zinco, em qualquer dos niveis de calagem.
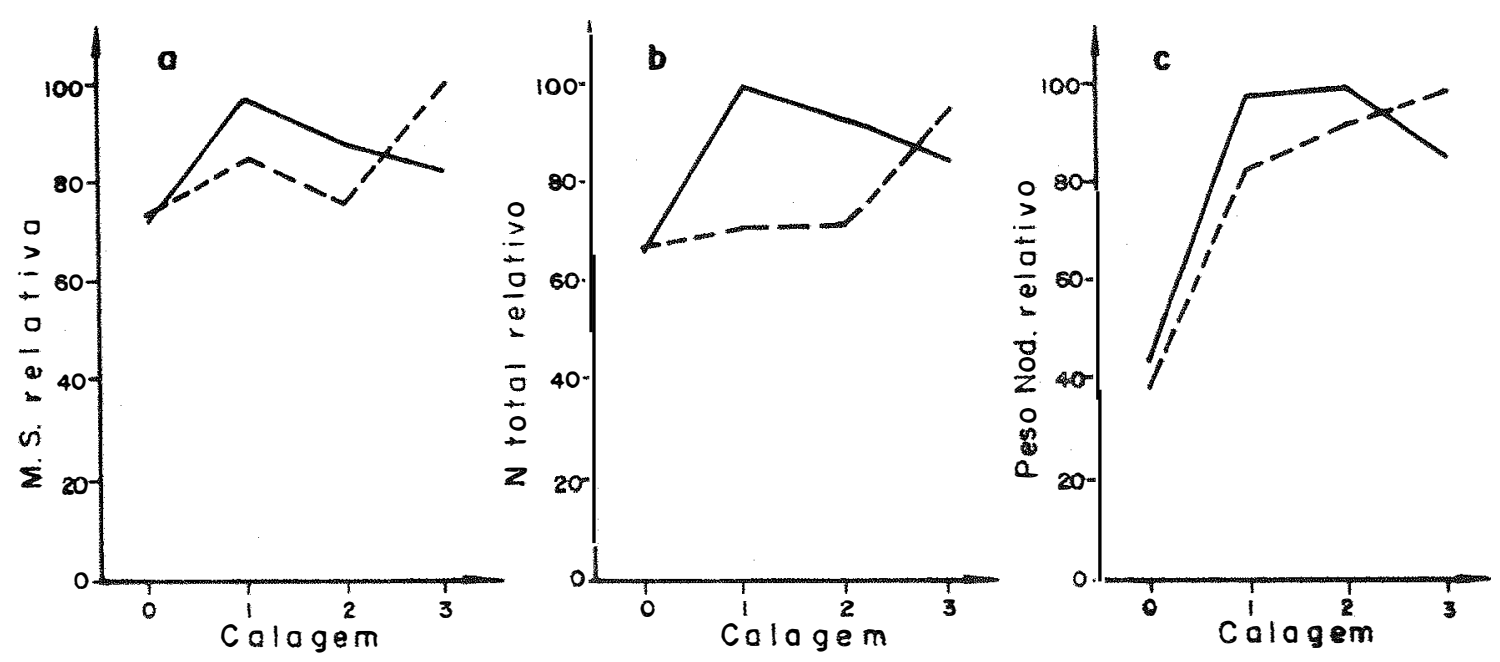

Fig. 9. Variações relativas na produção de matéria seca (a) e no nitrogênio total da planta inteira (b) e na nodulação (c) do siratro, mediante os nîveis de calagem, e adição de molibdēnio (-) ou de boro + cobre + zin$\operatorname{co}(--\longrightarrow)$.

4.3.4. Galactia

As significancias obtidas pelo teste $F$ para 0 efeito dos micronutrientes aplicados no cultivo da galactia, dentro de cada nível de calagem, constam nas Tabelas 25 e 26.

As anālises dos dados obtidos no primeiro corte da galactia (Tabela 25) revelam um efeito significativo e nega tivo da aplicação de boro + cobre + zinco na produção de matéria seca da parte aérea, dentro do nível 3 de calagem ( $p H$ inicial $=5,6$ e final $=5,8)$. Efeitos semelhantes, foram obtidos no presente experimento com soja perene e com centrosema, o 
que realça o fato de se estar deparando com algum problema específico para essas trēs espēcies, nessas condições.

Tabela 25. Significāncias do teste $F^{a}$ para o fatorial dos micronutrientes aplicados, dentro de cada nivel de ca lagem, para a galactia. Dados referentes à parte a rea obtida no primeiro corte da espēcie.

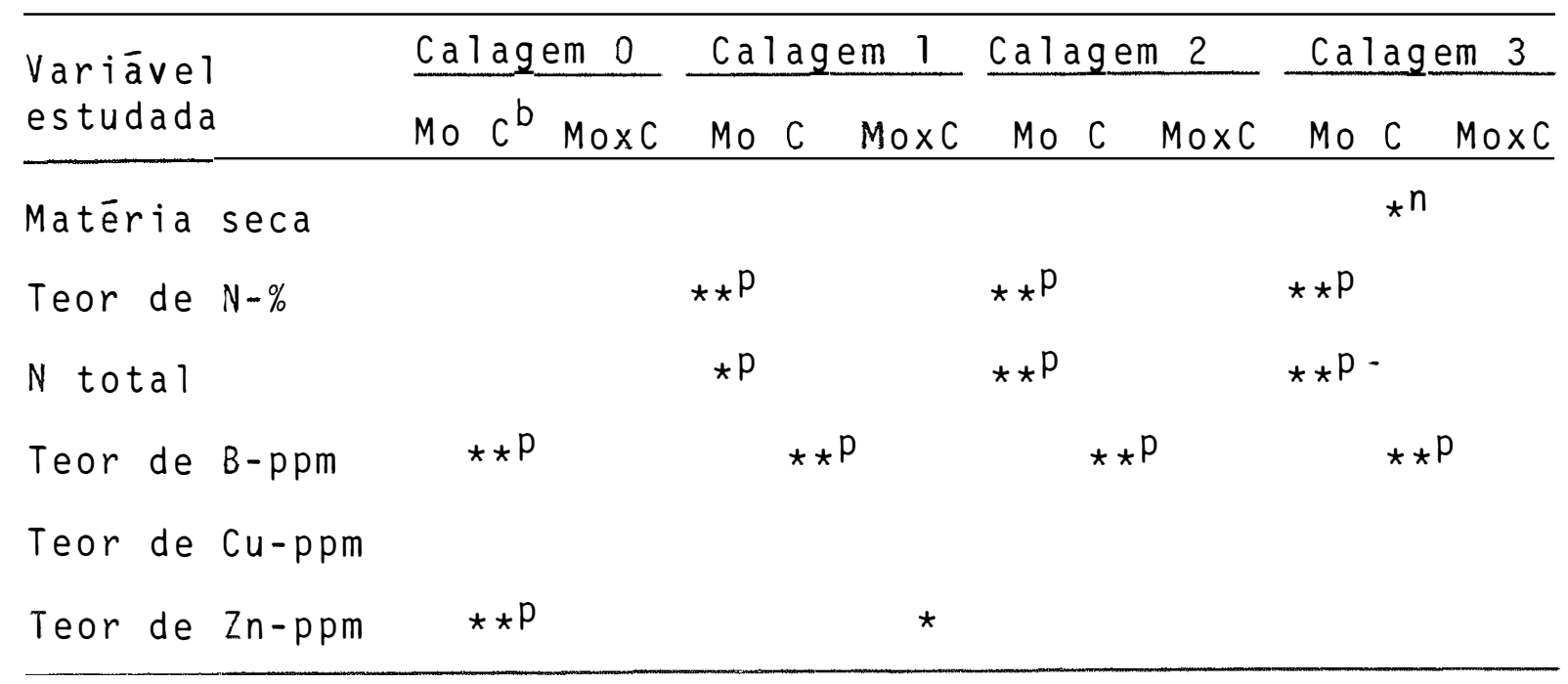

a. $\left({ }^{*}\right)$ e $(* *)=$ significàncias aos niveis de 5 e $1 \%$ de probabi lidade, respectivamente.

b. O simbolo C representa a aplicação conjunta de $B+C u+Z n$

p e $n$ = efeitos positivos e negativos, respectivamente.

Tanto a porcentagem de nitrogēnio quanto o nitro gênio total da galactia no primeiro corte (Tabela 25), foram significativamente incrementados pelo emprego do molibdénio, em presença dos níveis 1 (pH inicial = 5,1 e final = 5,3), 2 $(\mathrm{pH}$ inicial $=5,4$ e final $=5,6)$ ou 3 de calagem (pH inicial $=$ $5,6$ e final $=5,8)$. Efeitos semelhantes em leguminosas forra - 


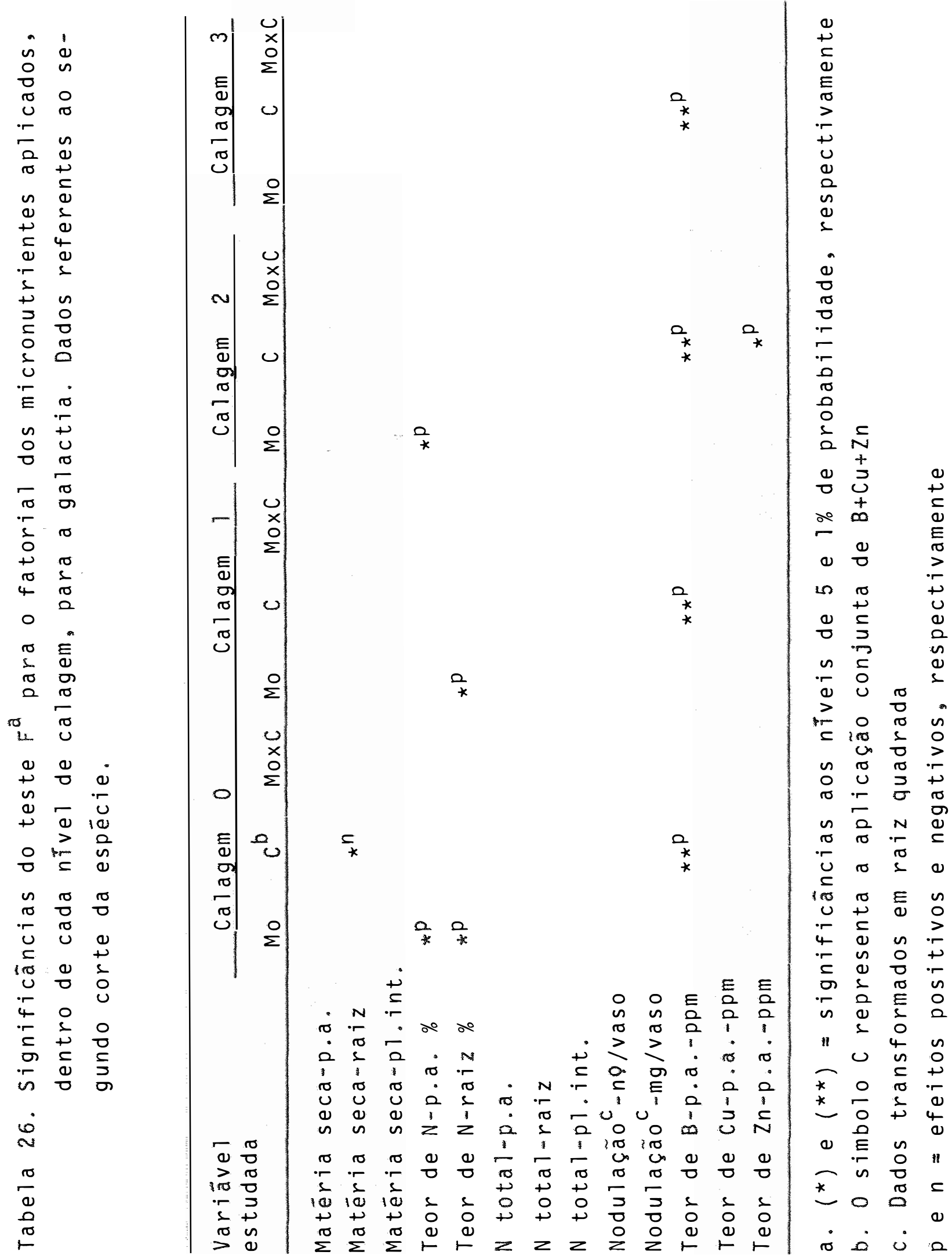


geiras foram observados por FRANÇA et alii (1973), WERNER e MATTOS (1974), MONTEIRO et alii (1975), WERNER e MATTOS (1975) e DE-POLLI et alii (1976).

Em termos da produção de matéria seca (parte aérea, raizes e planta inteira) verificada no segundo corte da leguminosa, o único efeito significativo da aplicação de micro nutrientes foi obtido com a adição de boro + cobre + zinco no nivel 0 de calagem ( $p H$ inicial $=4,7$ e final $=4,9)$ (Tabela 26). Tal efeito ocorreu com a produção de matéria seca das raízes.

A aplicação do molibdēnio, dentro do nível o de calagem, proporcionou acréscimo significativo no teor de nitro gênio na parte aérea e nas raízes da galactia (Tabela 26). Efeitos semelhantes para essa variável na parte aêrea, foram ve rificados dentro da dose 2 de calcário e nas raízes, dentro do nivel I de calagem. Conforme o discutido com os dados do pri meiro corte dessa espécie, a literatura aponta efeitos positivos do molibdènio sobre essas variáveis.

0 nitrogénio total no segundo corte da galactia e a nodulação observada, não sofreram qualquer variação significativa mediante o emprego dos micronutrientes estudados, em qualquer dos niveis de calagem.

A concentração de boro na parte aērea da galac tia, em ambos os cortes realizados e dentro de todos os niveis de calagem testados, foi significativamente aumentada pela aplicação de boro + cobre + zinco (Tabelas 25 e 26). MIRANDA (1979) verificou aumentos no teor de boro na parte aérea da ga 
lactia, cultivada em dois solos, mediante a aplicação desse mi cronutriente ao solo.

$$
\text { O teor de zinco na parte aérea da galactia, no }
$$
primeiro corte, foi significativamente aumentado como resultado da aplicação de boro + cobre + zinco em calagem o ou median te o emprego dos trés micronutrientes em ausência de molibdé nio, dentro do nīvel 1 de calcārio (Tabela 25). Já no segundo corte, esse efeito positivo somente ocorreu na aplicação de bo ro + cobre + zinco, na dose 2 de calagem (Tabela 26). Aumentos no teor desse micronutriente na parte aérea da galactia, com a adição do elemento na adubação, são relatados por MIRANDA (1979) em trabalho com um solo Podzólico Vermelho Amarelo. 
Com base nos resultados obtidos no presente tra balho pode-se apontar as seguintes conclusões:

1. O emprego das doses de calcārio dolomítico, avaliado à época do plantio das leguminosas, fez variar alguns parâmetros da anāilise química do solo nas seguintes faixas: pH de 4,7 a 5,6; alumínio trocável de 0,80 a 0,08, cálcio trocável de 0,30 a 1,18 e magnésio trocável de 0,10 a 0,60 equivalentes miligrama por cem mililitros de solo, porcentagem de saturação de bases de 12,1 a 44,8 por cento e por centagem de saturação de aluminio de 63,0 a 4,1 por cento;

2. Tanto a soja perene variedade Tinaroo como a centrosema apresentaram aumentos significativos e lineares na produção de matéria seca, no nitrogénio total acumulado e na 
nodulação até a maior dose de calcário aplicada (2,49 toneladas por hectare), planejada para elevar o pH do solo a 6,5, mas que efetivamente elevou o pH a 5,6 e conseguiu anular o aluminio trocável do solo. Os valores máximos para essas variáveis seriam obtidos com calagens superiores ao máximo nível testado, para esse solo e com ambas as leguminosas;

3. A produção de matēria seca e nitrogēnio to tais bem como a nodulação do siratro se deram segundo uma equação do terceiro grau, em relação à calagem. O máximo valor do nitrogénio total no siratro seria obtido, no solo estudado, com o emprego de uma tonelada de calcário dolomítico por hectare, o que proporcionaria no solo um pH de 5,18; aluminio trocável de 0,35 , cálcio mais magnēsio trocáveis de 1,03 equi valentes miligrama por cem mililitros de solo, porcentagem de saturação de bases de 27,2 por cento e porcentagem de saturação de aluminio de 24,8 por cento, à época do plantio do experimento.

4. Para a galactia, a produção de matéria seca e o nitrogênio total da parte aérea, no primeiro corte do ensaio seguiram uma variação linear, em função da calagem. No segundo corte do experimento, a produção de matēria seca, nitrogênio total da planta e a nodulação seguiram uma equação de terceiro grau. O valor máximo para o nitrogênio total na segunda colheita ocorreria, nesse solo, mediante a aplicação de 0,72 toneladas de calcārio dolomitico por hectare. Essa ca lagem resultaria, à ëpoca do plantio do ensaio, em valores no solo de pH=5,05; alumīnio trocável de 0,45, cálcio mais magne 
sio trocáveis de 0,86 equivalentes miligrama por cem mililitros de solo, uma porcentagem de saturaçào de bases de 23,2 por cento e uma porcentagem de saturação em aluminio de 33,2 por cento;

5. Na ausēncia de calagem, a soja perene variedade Tinaroo mostrou altos teores de manganés na parte aérea, que resultaram em sintomas visuais de toxidez desse micronu triente nessa leguminosa. 0 excesso desse micronutriente seria um dos problemas nas condições mais ácidas do solo estuda do, para normais nodulação e desenvolvimento dessa espécie;

6. O emprego dos níveis de calcário dolomitico resultou em variações significativas nos teores de macro e mi cronutrientes na parte aérea das leguminosas testadas;

7. O molibdénio foi, entre os micronutrientes, - que proporcionou as maiores respostas favoráveis nas legumi nosas estudadas, porém essa ação benēfica não ocorreu ém ausência de calagem, quando o solo tinha um pH de 4,7, por ocasião da semeadura do experimento;

8. Para a soja perene variedade Tinaroo, o molibdênio proporcionou respostas positivas quando empregado em presença das doses de 0,$83 ; 1,66$ ou 2,49 toneladas de calcário dolomitico por hectare;

9. O molibdēnio, em ausência da aplicação de bo ro, cobre e zinco, resultou em efeitos benëficos para a centrosema, ao ser adicionado em solo que havia recebido 1,66 ou 
2,49 toneladas de calcário dolomitico por hectare. Nas condi ções da mais elevada calagem, o emprego conjunto de boro, sobre e zinco proporcionou efeitos negativos na produção de matēria seca da parte aérea e da planta inteira dessa leguminosa.

10. Em presença da dose menor de calagem (de 0,83 toneladas de calcário dolomítico por hectare), o siratro teve efeitos favoráveis da aplicação do molibdēnio e depress $\underline{i}$ vos do emprego conjunto de boro, cobre e zinco. Estes trés mi cronutrientes juntos, tiveram efeitos positivos no siratro, quando aplicados ao solo que recebera a maior dose de calagem (2,49 toneladas por hectare).

11. A galactia, a se julgar pelo que ocorreu no primeiro corte do experimento, mostrou expressivas respostas ao emprego do molibdénio, quando o calcário dolomítico foi adicionado ao solo;

12. A aplicação conjunta de boro, cobre e zinco resultou em significativos acréscimos no teor de boro na parte aérea das quatro leguminosas e em qualquer dos níveis de calagem testados. 
6. LITERATURA CITADA

ANDREW, C.S. E D.O. NORRIS. 1961. Comparative responses to calcium of five tropical and four temperate legume species. Aust. J.agric. Res., Melbourne, 12:40-45.

ANDREW, C.S. 1962. Influence of nutrition on nitrogen fixation and growth of legumes. In: Comittee of the Division of Tropical Pastures, CSIRO, Austrālia, Ed. A review of nitrogen in the tropics with particular reference to pastures; a symposium. Farnham Royal, Bucks, Commonwealth Agricultural Bureaux, p. 130-146. Bulletin 46.

ANDREW, C.S. P P.M. THORNE. 1962. Comparative responses to copper of some tropical and temperate pasture legumes. Aust. J. agric. Res., Melbourne, 13:821-835. 
ANDREW, C.S. e M.P. HEGARTY. 1969. Comparative responses to manganese excess of eight tropical and four temperate pasture legume species. Aust. J.agric. Res., Melbourne, 20: 687-696.

ANDREW, C.S. e W.H.J. PIETERS, 1970. Manganese toxicity symptoms of one temperate and seven tropical pasture legumes. Tech. Pap. Div. Trop. Past. CSIR0 Aust., Melbourne, n. 4. $8 p$.

ANDREW, C.S., A.D. JOHNSON E R.L. SANDLAND. 1973. Effect of aluminum on the growth and chemical composition of some tropical and temperate pasture legumes. Aust. J.agric. Res., Melbourne, 24:325-339.

ANDREW, C.S. 1976. Effect of calcium, pH and nitrogen on the growth and chemical composition of some tropical and tempe rate pasture legumes. I. Nodulation and growth. Aust. J. agric. Res., Melbourne, 27:611-623.

ANDREW, C.S. 1978. Legumes and acid soils. In: DÖBEREINER, J., R.H. BURRIS e A. HOLLAENDER, ed. Limitations and poten. tials for biological nitrogen fixation in the tropics. New York, Plenum, p. 135-160.

ASHER, C.J. 1979. Revisão sobre a natureza geral dos problemas de fertilidade dos solos ácidos. In: BOOK, A. e A.L. GARDNER, ed. Nutrição de plantas forrageiras em solos tro. picais ácidos. Campo Grande, M.S., Centro Nacional de Pes quisa de Gado de Corte, p. 4-20. 
BRAZON, C.A.A. 1971. Efeitos da aplicação de calcārio, fósfó ro, potássio e inoculante sobre a produção de matéria seca, nodulação e composição quỉmica de Phaseolus atropurpureus DC CV. Siratro. Piracicaba, ESALQ/USP, 61 p. (Disserta ção de Mestrado).

BUCKMAN, H.O. e N.C. BRADY. 1968. Natureza e propriedades dos solos; trad. E.B.N. Figueiredo Filho. Rio de Janeiro, Livraria Freitas Bastos, $594 \mathrm{p}$.

CAMARGO, O.A. e B. VAN RAIJ. 1976. Relações entre aluminio trocāvel, bases trocāveis e pH em solos. In: Anais do XV Congresso Brasileiro de Ciência do Solo, Campinas, p. 95101.

CARTWRIGHT, B. e E.G. HALLSWORTH. 1970. Effects of copper deficiency on root nodules of subterranean clover. Pl. So i1, The Hague, 33:685-698.

CARVALHO, M.M., G.E. FRANÇA, A.F.C. BAHIA FILHO e O.L. MOZZER. 1971. Ensaio exploratōrio de fertilização de seis leguminosas tropicais em um latossolo vermelho-escuro, fase mata. Pesq. agropec. bras. Rio de Janeiro, 6:285-290.

CARVALHO, M.M., O.L. MOZZER, J.G. FERREIRA e A.F.C. BAHIA FILHO. 1974. Efeito de fontes de fósforo e corretivos do so 10 em duas leguminosas tropicais. In: Anais da XI Reunião da Sociedade Brasileira de Zootecnia, Fortaleza, p. 326 327. 
CATANI, R.A. e 0. ALONSO. 1969. Avaliação da exigéncia de cal cário do solo. Anais Esc. sup. Agric. Luiz de Queiroz, Piracicaba, 26:141-156.

CATANI, R.A. e A.0. JACINTHO. 1974. Avaliação da fertilidade. do solo-métodos de análise. Piracicaba, Livroceres, $61 p$.

COLEMAN, N.T. e E.W. THOMAS. 1967. The basic chemistry of soil acidity. In: PEARSON, R.W. e F. ADAMS, ed. Soil acidity and liming. Madison, Am. Soc. Agron., p. 1-41.

DEFELIPO, B.V., J.M. BRAGA e C. SPIES. 1972. Comparação entre métodos de determinação da necessidade de calcārio de solos de Minas Gerais. Experientiae, Viçosa, 13:111-136.

DE-POLLI, H. e J. DOBBEREINER. 1974. Deficiēncia de micronutrí entes em um solo Podzólico Vermelho-Amarelo e sua correção com "pellet" de F.T.E.. Pesq. agropec. bras., Rio de Janei ro, 9 : $93-99$.

DE-POLLI, H., A.R. SUHET e A.A. FRANCO. 1976. Micronutrientes limitando a fixação de nitrogênio atmosférico e produção de centrosema em solo Podzólico Vermelho Amarelo. In: Anais do XV Congresso Brasileiro de Ciência do Solo, Campinas, $p$. $151-156$.

DÖBEREINER, J. e S. ARONOVICH. 1966. Efeito da calagem e da temperatura do solo na fixação de nitrogēnio de Centrosema pubescens Benth, em solo com toxidez de manganés. In: Anais do 90 Congresso Internacional de Pastagens, São Paulo, v. 2 p. $1121-1124$. 
EIRA, P.A., P.L. ALMEIDA e W.C. SILVA. 1972. Fatores nutricio nais limitantes do desenvolvimento de trés leguminosas forrageiras em solo podzólico vermelho-amarelo. Pesq.agropec. bras., Rio de Janeiro, $\underline{7}: 185-192$.

EMPRESA BRASILEIRA DE PESQUISA AGROPECUARIA. Centro Nacional de Pesquisa de Gado de Corte. 1979. Relatório técnico anual: 1976-78. Brasilia, 120p.

EPSTEIN, E. 1975. Nutrição mineral das plantas: princípios e perspectivas; trad. e notas de E. Malavolta. Rio de Janeiro, Livros Técnicos e Científicos; São Paulo, Editora da Univ. São Paulo, $341 \mathrm{p}$.

FRANÇA, G.E. e M.M. CARVALhO. 1970. Ensaio exploratōrio de fertilização de cinco leguminosas tropicais em um solo de cerrado. Pesq. agropec. bras., Rio de Janeiro, 5:147-153.

FRANÇA, G.E., A.F.C. BAHIA Filho e M.M. CARVALho. 1973. Influēncia de magnésio, micronutrientes e calagem no desenvol vimento e fixação simbiótica de nitrogênio na soja perene var. Tinaroo (Glycine wightii) em solo de cerrado. Pesq. agropec. bras., Rio de Janeiro, 8:197-202.

FRANCO, A.A. e J. DÖBEREINER. 1971. Toxidez de manganês de um solo äcido na simbiose soja-Rhizobium. Pesq. agropec. bras. $\underline{6}: 57-66$.

FRANCO, A.A. 1978. Micronutrient requirements of legume-Rhizo bium symbiosis in the tropics. In: DÖBEREINER, J., R.H. BURRIS e A. HOLLAENDER, ed. Limitations and potentials for 
biological nitrogen fixation in the tropics. New York, Plenum, p. 161-171.

FREITAS, L.M.M. e P.F. PRATT. 1969. Respostas de três legumí nosas a calcário em diversos solos ácidos de São Paulo. Pesq. agropec. bras., Rio de Janeiro, 4:89-95.

GAVAZONI, J.C., J.A. GOMIDE e J.C. GOMES. 1979. Resposta do siratro à aplicação de fósforo, potássio, calcārio e micro nutrientes. Revta. Soc. bras. Zoot., Viçosa, 8:407-420.

HALLSWORTH, E.G. 1958. Nutritional factors affecting nodulation. In: HALLSWORTH, E.G., ed. Nutrition of the legumes. London, Butterworths, p. 183-201.

HEWITT, E.J. 1958. Some aspects of mineral nutrition. In : HALLSWORTH, E.G., ed. Nutrition of the legumes. London, Butterworths, p. 15-42.

JACKSON, W.A. 1967. Physiological effects of soil acidity. In: PEARSON, R.W. e F. ADAMS, ed. Soil acidity and liming. Madison, Am. Soc. Agron., p. 43-134.

JONES, M.B. e L.M.M. FREITAS. 1970. Respostas de quatro legu minosas tropicais a fósforo, potássio e calcārio, num Lató sol Vermelho-Amarelo de campo cerrado. Pesq. agropec. bras., Rio de Janeiro, 5:91-99.

JONES, M.B., J.L. QUAGLIATO e L.M.M. FREITAS. 1970. Respos tas de alfafa e algumas leguminosas tropicais à aplicações de nutrientes minerais, em trés solos de campo cerrado. Pesq. agropec. bras., Rio de Janeiro, 5:209-214. 
JONES, R.J. 1974. Proposta de zoneamento de plantas forragei ras para o Estado de São Paulo. Zootecnia, São Paulo, 12: $177-190$.

KAMPRATH, E.J. 1970. Exchangeable aluminum as a criterionfor liming leached mineral soils. Proc. Soil Sci. Soc. Am., Madison, $34: 252-254$.

KAMPRATH, E.J. 1972. Soil acidity and liming. In: COMItTEE ON TROPICAL SOILS, ed. Soils of the humid tropics. Washington, National Academy of Sciences, p. 136-149.

KOLLING, J. J.G. STAMMEL e E. KORNELIUS. 1974. Efeitos da ca lagem e da adubação fosfatada sobre a nodulação, nitrogé nio total no tecido e produção de matéria seca de leguminosas forrageiras de clima tropical. Agronomia sulriogr., Porto Alegre, 10:267-280.

KORNELIUS, E. e J.G. STAMMEL. 1973. Respostas de duas legumi nosas tropicais a fósforo e calcārio em um solo ácido do Rio Grande do Sul. In: Anais da X Reunião da Sociedade Brasileira de Zootecnia e I Congresso Brasileiro de Forrageiras, Porto Alegre, p. 421-422.

LINDSAY, W.L. 1972. Inorganic phase equilibria of micronutri ents in soils. In: MORTVEDT, J,J., P.M. GIORDANO e W.L. LINDSAY, ed. Micronutrients in agriculture. Madison, Soil Sci. Soc. Am., p. 41-57. 
LOTT, W.L., J.P. NERY, J.R. GALLO e J.C. MEdCALF. 1956. A téć nica de anālise foliar aplicada ao cafeeiro. Bull. IBEC Res. Inst., New York, n. 9, 40p.

LOVADINI, L.A.C. 1972. Comportamento da soja perene (Glycine wightii Verdc) em solos ācidos, em função das variações de pH, Al trocável e do fósforo aplicado como fosfato solúvel. Piracicaba, ESALQ/USP, 94p. (Tese de Doutoramento).

LOVADINI, L.A.C., E.A. BULISANI E H.A.A. MASCARENHAS. 1977. Efeito de níveis de calagem, fósforo e potássio na produção de matéria seca de soja perene (Glycine wightii Verdc) em solos de cerrado. Revta.bras. Cienc. Solo, Campinas, I: $31-34$.

MALAVOLTA, E. 1976. Manual de quĩmica agrícola: nutrição de plantas e fertilidade do solo. São Paulo, Ed. Agronomica Ceres, 528p.

MATTOS, H.B. 1972. Efeitos da aplicação de calcārio e micronu trientes sobre a produção de matéria seca, nodulação e composição quîmica de Phaseolus atropurpureus DC CV. Siratro. Piracicaba, ESALQ/USP, 117p. (Tese de Doutoramento).

MATTOS, H.B. e J.C. WERnER. 1972. Efeito da aplicação de nutrientes minerais em Galactia striata cultivada em um solo de Nova Odessa. In: Anais da IX Reunião da Sociedade Brasi leira de Zootecnia, Viçosa, p. 261-262.

MATTOS, H.B. e P.B. ALCÃNARA. .1976. Galactia striata, promis sora leguminosa para o Brasil Central. Zootecnia, Nova 0- 
dessa, $14: 51-57$.

MIRANDA, M.T. 1979. Contribuição ao estudo da nutrição mineral e da adubação do siratro (Macroptilium atropurpureum, DC Cv. Siratro), galactia (Galactia striata, (Jacq.) Urb.) e soja perene comum (Glycine wightii, Willd) em dois solos do Estado de São Paulo. Piracicaba, ESALQ/USP, 132p. (Dís sertação de Mestrado).

MONTEIRO, F.A., J.C. WERNER E M.A. SANTOS. 1975. Fatorial BX MoxCuxZn em Centrosema pubescens Benth, com solo de Andradina, SP. In: Anais da XII Reunião da Sociedade Brasileira de Zootecnia, Brasilia, p. 82-83.

MUNNS, D.N. 1970. Nodulation of Medicago sativa in solution culture. V. Calcium and $\mathrm{pH}$ requirements during infection. P1. Soil, The Hague, 32: 90-102.

MUNNS, D.N. e R.L. FOX. 1977. Comparative lime requirements of tropical and temperate legumes. Pl. Soil, The Hague, 46: $533-548$.

MUNNS, D.N., R.L. FOX e B.L. KOCH. 1977. Influence of lime on nitrogen fixation by tropical and temperate legumes. P1. Soil, The Hague, 46:591-601.

NEME, N.A. e L.A.C. LOVADINI. 1967. Efeito de adubos fosfata dos e calcário na produção de forragem de soja perene em terra de cerrado. Bragantia, Campinas, 26:365-371. 
NePtUNe, A.M.L. 1975. Aplicação de calcário em culturas forrageiras. In: Anais do 20 Simpósio sobre Manejo da Pastagem, Piracicaba, ESALQ/USP, p.49-86.

NERY, M., J.R.R. PERES e J. DÖBEREINER. 1976. Efeito de micronutrientes na forma de F.T.E. na produção de legumino sas forrageiras e fixação de nitrogênio. In: Anais do XV Congresso Brasileiro de Ciência do Solo, Campinas, p. 157162.

NEYRA, C.A. 1978. Interactions of plant photosynthesis with dinitrogen fixation and nitrate assimilation. In: DÖBEREI NER, J., R.H. BURRIS e A. HOLLAENDER, ed. Limitations and potentials for biological nitrogen fixation in the tropics. New York, Plenum, p. $111-120$.

NORRIS, D.0. 1958. Lime in relation to the nodulation of tro pical legumes. In: HALLSWORTH, E.G., ed. Nutrition of the. legumes. London, Butterworths, p. 164-182.

NORRIS, D.0. 1959. The role of calcium and magnesium in the nutrition of Rhizobium. Aust. J.agric. Res., Melbourne, 10: $651-696$.

ODU, C.T.I., A.A. FAYEMI E J.A. OGUNWALE. 1971. Effect of pH on the growth, nodulation and nitrogen fixation of centrosema pubescens and Stylosanthes gracilis. J.Sci.Fd. Agric., London, 22:57-59.

PERKIN-ELMER CORPORATION. 1976. Analytical methods for atomic absorption spectrophotometry. Hartford, Perkin Elmer, $45 p$. 
PIMENTEL GOMES, F. 1970. Curso de estatistica experimental.

4. ed. Piracicaba, Livraria Nobel, $430 \mathrm{p}$.

PRICE, C.A., H.E. CLARK e E.A. FUNKHOUSER. 1972. Functions of micronutrients in plants. In: MORTVEDT, J.J., P.M. GIORDANO e W.L. LINDSAY, ed. Micronutrients in agriculture. Madison, Soil Sci.Soc. Am., p. 231-242.

QUAGLIATO, J.L. 1966. Produção de leguminosas forrageiras nos trópicos. Piracicaba, ESALQ/USP, 14 p. (Curso Pós-Graduado de Nutrição Animal e Pastagens).

QUAGLIATO, J.L. e P. NUTI. 1969. Efeito da calagem e micronutrientes na produção de leguminosas forrageiras em solos de cerrado. In: 1o Encontro de Técnicos da Região Centro-Sul para Discussão de Problemas Relacionados às Leguminosas For rageiras, Nova Odessa, $3 p$.

RiBEIRO, G.L., R. GARCIA, A.T. RADIM e J.A. GOMIDE. 1970. Res postas da soja perene (Glycine javanica) à inoculação com Rhizobium cowpea, calagem e adubação fosfatada e potássica. In: Anais da VII Reunião da Sociedade Brasileira de Zootecnia, Piracicaba, p. 16-17.

RORISON, I.H. 1958. The effect of aluminum on legume nutrition. In: HALLSWORTH, E.G., ed. Nutrition of the legumes. London, Butterworths, p. 43-61.

SARRUGE, J.R. e H.P. HAAG. 1974. Anālises quĩmicas em plantas. Piracicaba, ESALQ/USP, 56p. 
SIQUEIRA, C. e A.C. VELOSO. 1978. Adsorção de molibdato em solos sob vegetação de cerrado. Revta. bras. Cienc. Solo, Campinas, 2:24-28.

SOARES, W.V. e M.A.T. VARGAS. 1974. Ensaio exploratōrio de fertilização com duas leguminosas tropicais em trés solos sob cerrado do Distrito Federal. In: Anais do XIV Congres so Brasileiro de Ciēncia do Solo, Santa Maria, p. 448-460.

SOARES, W.V. 1979. Descrição geral dos solos de cerrado e progresso obtido na identificação de limitações reais e potenciais de nutrientes nos mesmos. In: B00K, A. e A.L. GARDNER, ed. Nutrição de plantas forrageiras em solos tro. picais àcidos. Campo Grande, M.S., Centro Nacional de Pes quisa de Gado de Corte, p. 32-46.

SOUTO, S.M. e J. DÖBEREINER. 1969. Toxidez de manganês em le guminosas forrageiras tropicais. Pesq. agropec. bras., Rio de Janeiro, $4: 129-138$.

TEITZEL, J.K. 1969. Responses to phosphorus, copper and potassium on a granite loam of the wet tropical coast of Queensland. Trop. Grass., Brisbane, 3:43-48.

TEITZEL, J.K. e R.C. BRUCE. 1971. Fertility studies of pastu re soils in the wet tropical coast of Queensland. 2. Grani tic soils. Aust. J. exp. Agric. anim. Husb., Melbourne, 11: $77-84$. 
TEITZEL, J.K. e R.C. BRUCE. 1972. Fertility studies of pastü re soils in the wet tropical coast of Queensland. 3. Basal tic soils. Aust. J. exp. Agric. anim. Husb., Melbourne, 12:49-54.

TEITZEL, J.K. e R.C. BRUCE. 1973. Fertility studies of pastü re soils in the wet tropical coast of Queensland. 6. Soils derived from beach sand. Aust. J. exp. Agric. anim. Husb., Melbourne, 13:312-318.

TISDALE, S.L. e W.L. NELSON. 1975. Soil fertility and fertilizers. 3. ed. New York, Mac Millan, 694p.

TRIGOSO, R. e H.W. FASSBENDER. 1973. Efecto de aplicaciones de Ca+Mg, P, Mo y B sobre la producción y fijación de nitrōgeno de cuatro leguminosas tropicales. Turrialba, 23: $172-180$.

TRUONG, N.V., C.S. ANDREW e P.J. SKERMAN. 1967. Responses by siratro (Phaseolus atropurpureus) and white clover (Trifolium repens) to nutrients on solodic soils at Beaudesert, Queensland. Aust. J. exp. Agric. anim. Husb., 7:232-236.

TRUONG, N.V., C.S. ANDREW e G.L. WILSON. 1971. Manganese toxicity in pasture legumes. II. Effects of $\mathrm{pH}$ and molybde num levels in the substrate. Pl. Soil, The Hague, 34:547560 .

VAN RAIJ, B. 1975. Interpretação da análise de terra. Campi nas, Instituto Agronómico de Campinas, $8 p$. 
YUAN, T.L. 1963. Some relationships among hydrogen, aluminum and pH in solutions and soil systems. Soil Sci, New Jersey, $95: 155-163$.

WERNER, J.C. e H.B. MATTOS. 1972. Estudos de nutrição da cen trosema, Centrosema pubescens, Benth. Bolm. Ind. anim., São Paulo, 29:375-391.

WERNER, J.C. E H.B. MATTOS. 1974. Ensaio de fertilização com alguns micronutrientes em soja perene, Glycine wightii, Willd. Bolm. Ind. anim., São Paulo, 31:313-324.

WERNER, J.C. 1975. Uso de micronutrientes em pastagens. In: Anais do 20 Simpósio sobre Manejo da Pastagem , Piracicaba, ESALQ/USP, p. 87-111.

WERNER, J.C. e H.B. MATTOS. 1975. Ensaio de fertilização com quatro micronutrientes em Centrosema pubescens, Benth. Bolm. Ind. anim., São Paulo, 32:123-135.

WERNER, J.C., F.A. MONTEIRO e H.B. MATTOS. $1975^{\text {a }}$. Emprego de micronutrientes na forma de elementos traços fundidos (F.T. E.) em leguminosas forrageiras tropicais. Bolm. Ind. anim., São Paulo, 32:347-361.

WERNER, J.C., F.A. MONTEIRO e M.A. SANTOS. $1975^{\mathrm{b}}$. Fatorial BX MoxCuxzn em Centrosema pubescens, Benth com solo de São Jo Sé do Rio Preto, SP. In: Anais da XII Reunião da Sociedade Brasileira de Zootecnia, Brasilia, p.68-69.

WERNER, J.C. 1977. Adubação de pastagens. In: IO Encontrode Atualização em Pastagens. São Paulo, NESTLE, p. 43-63. 
7. APENDICE 


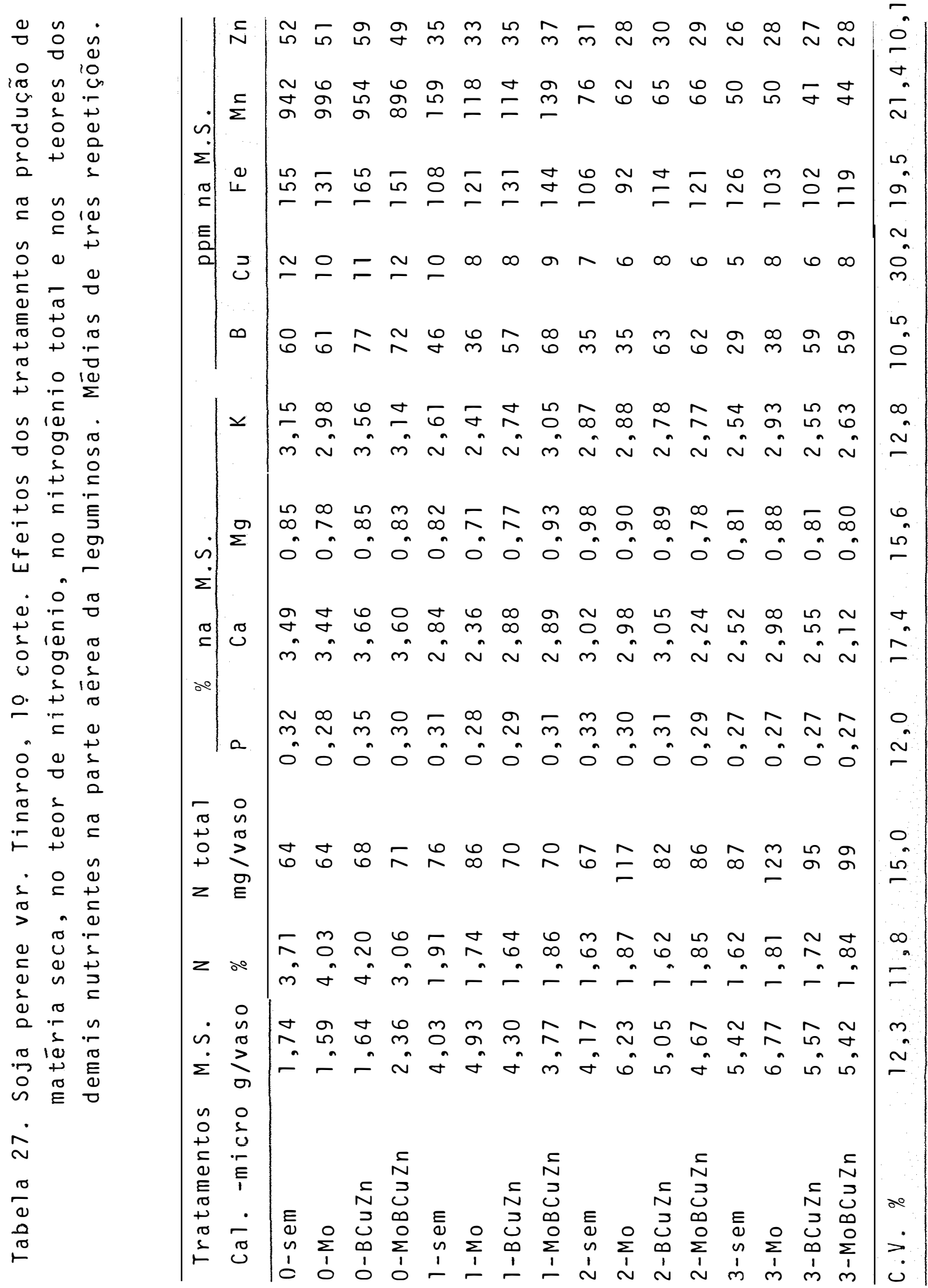



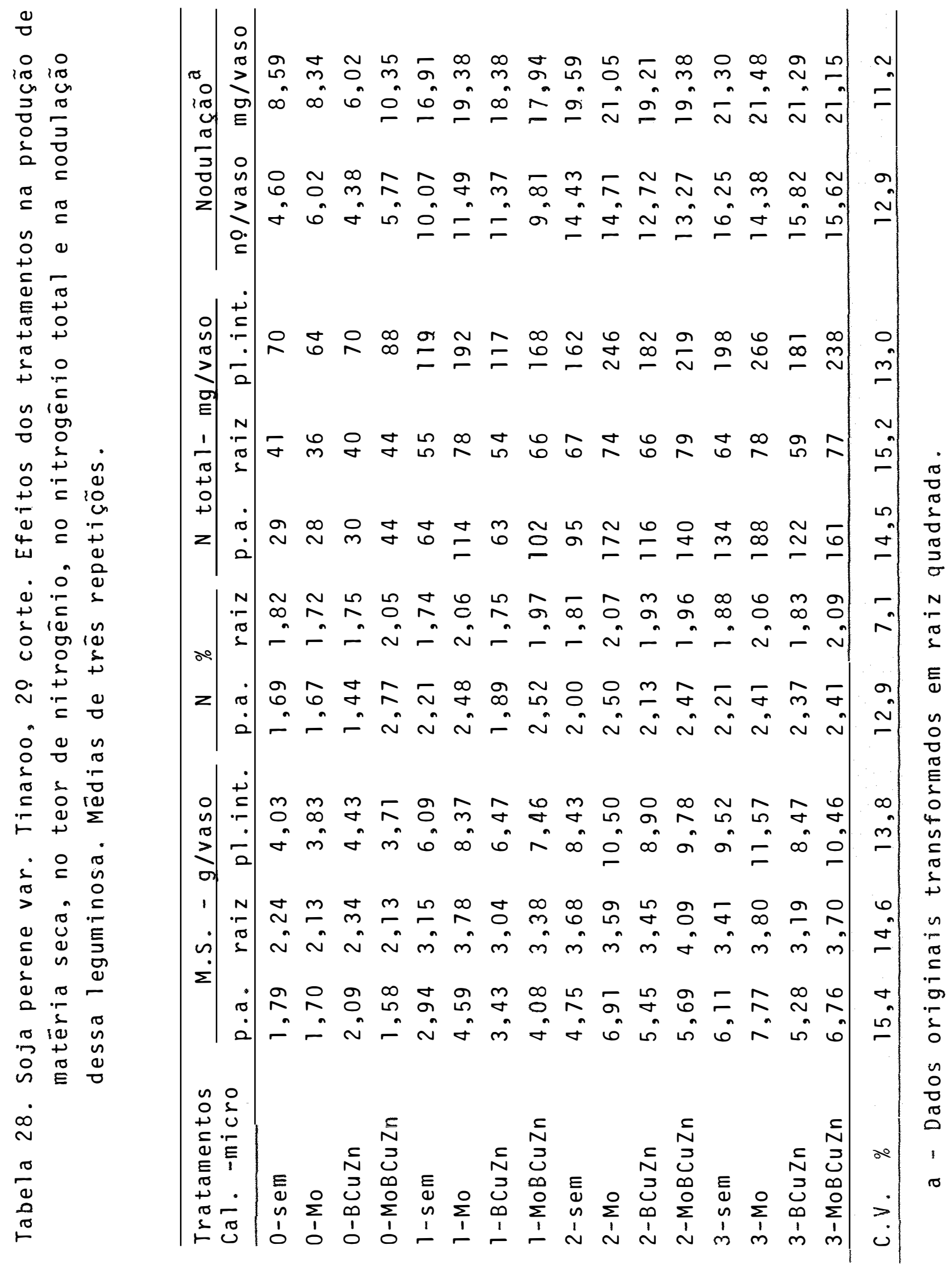


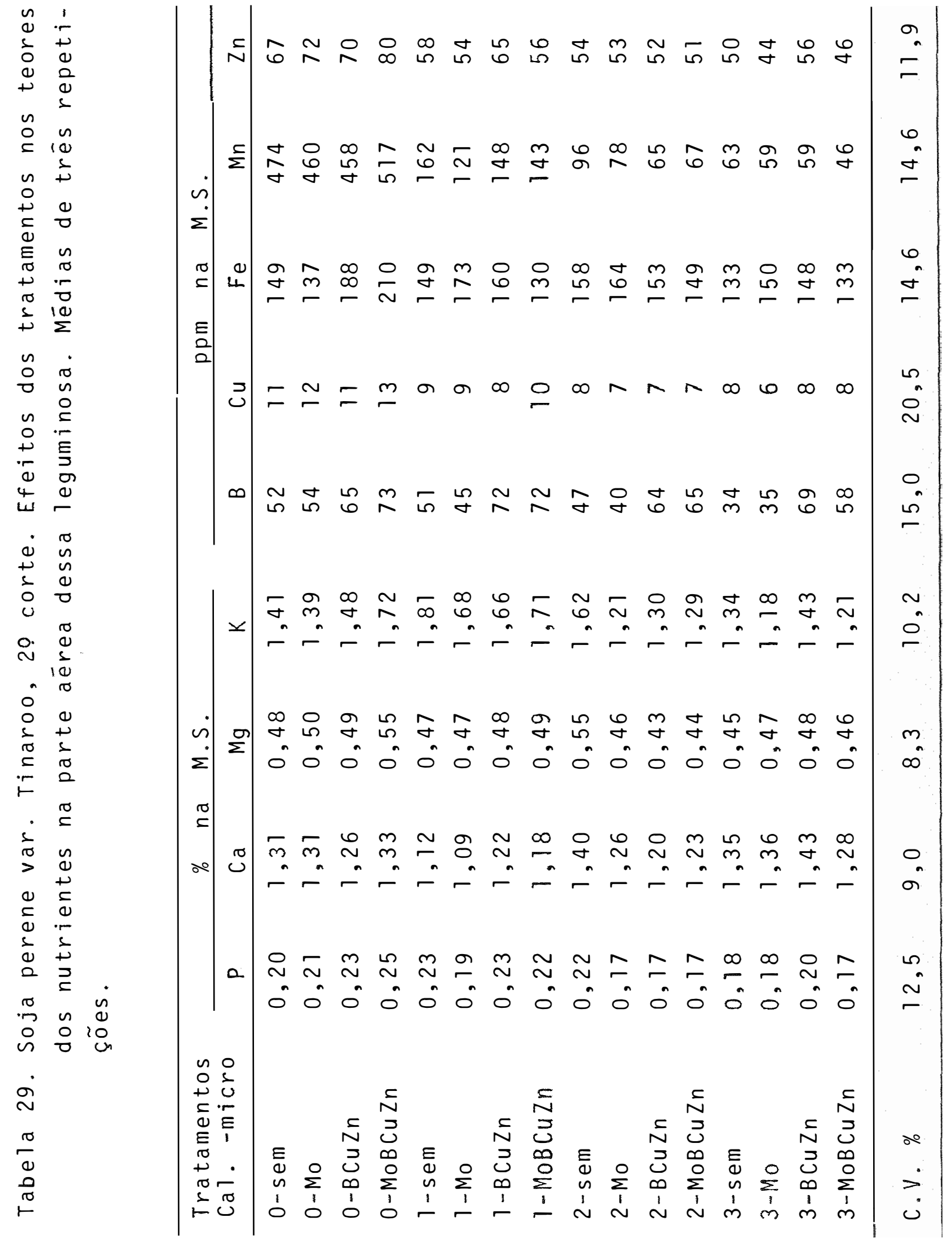




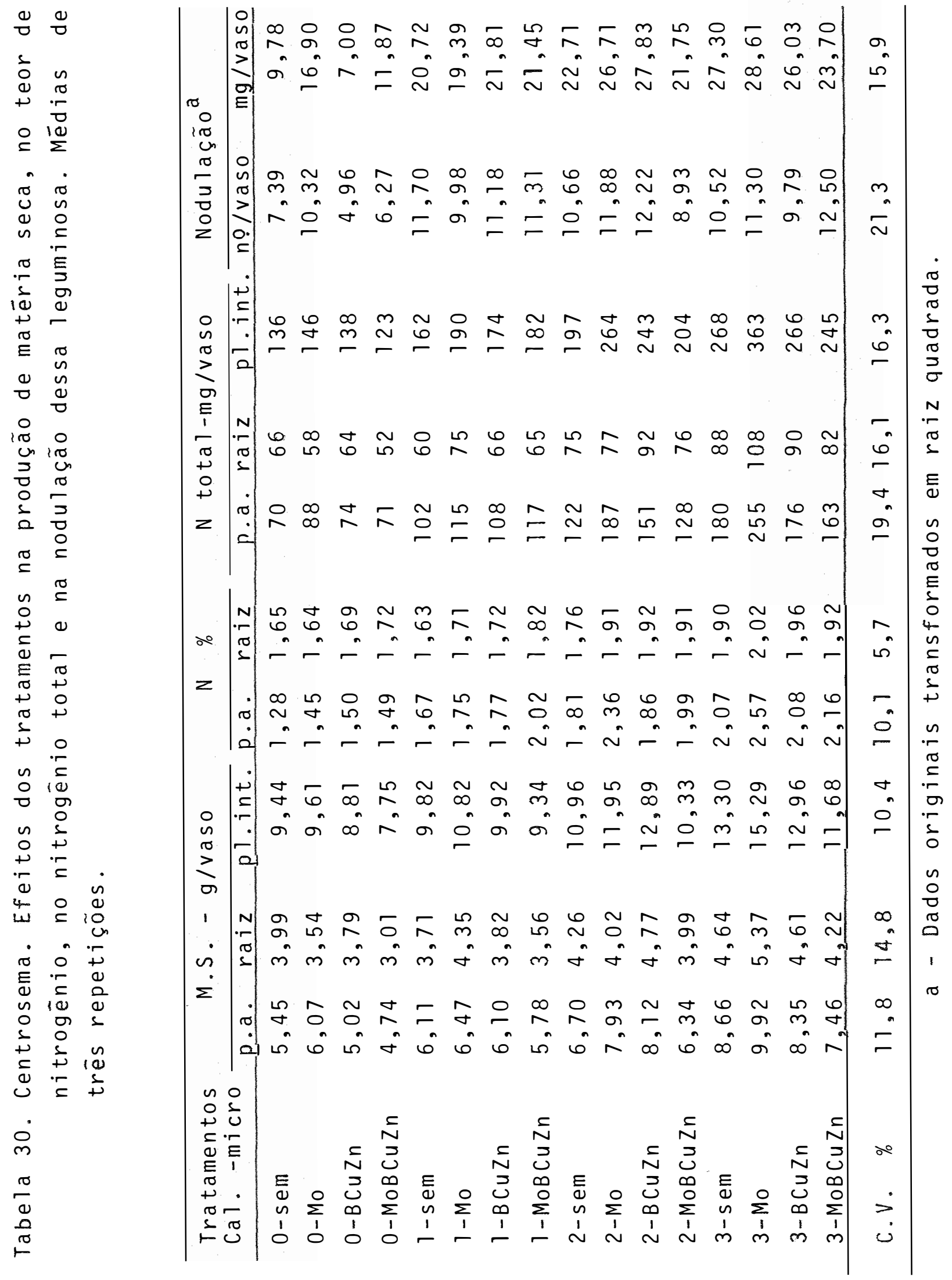




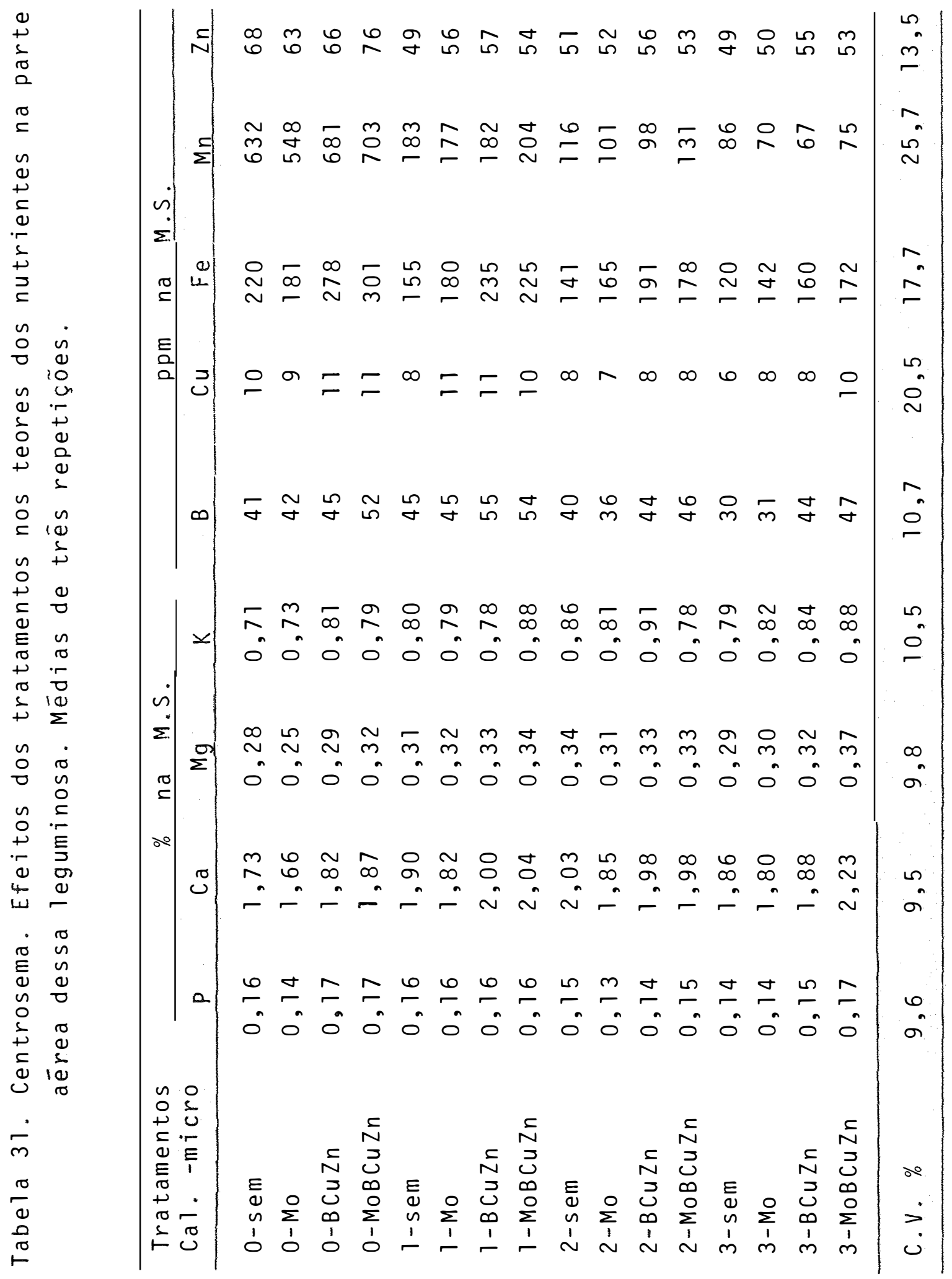



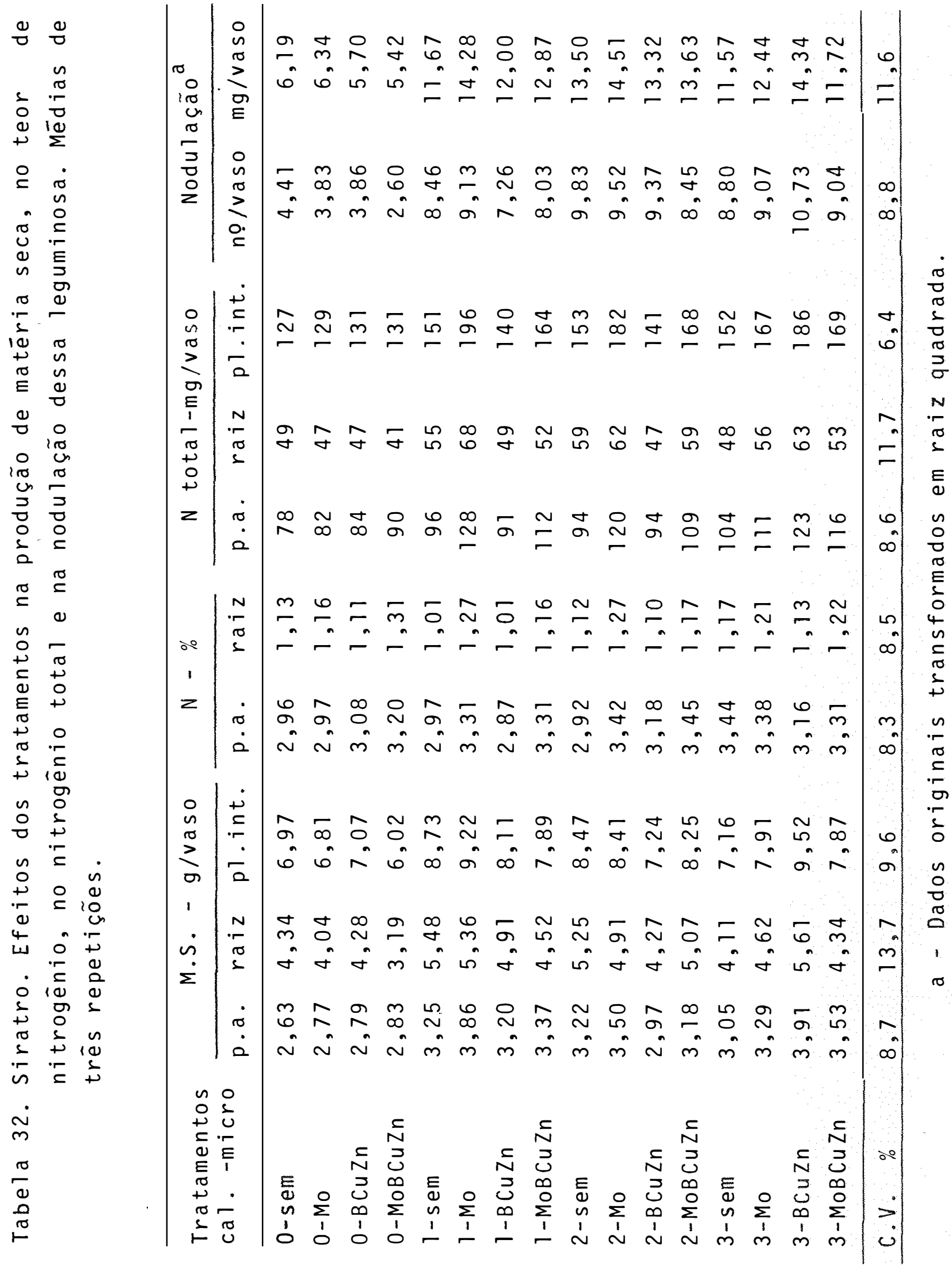


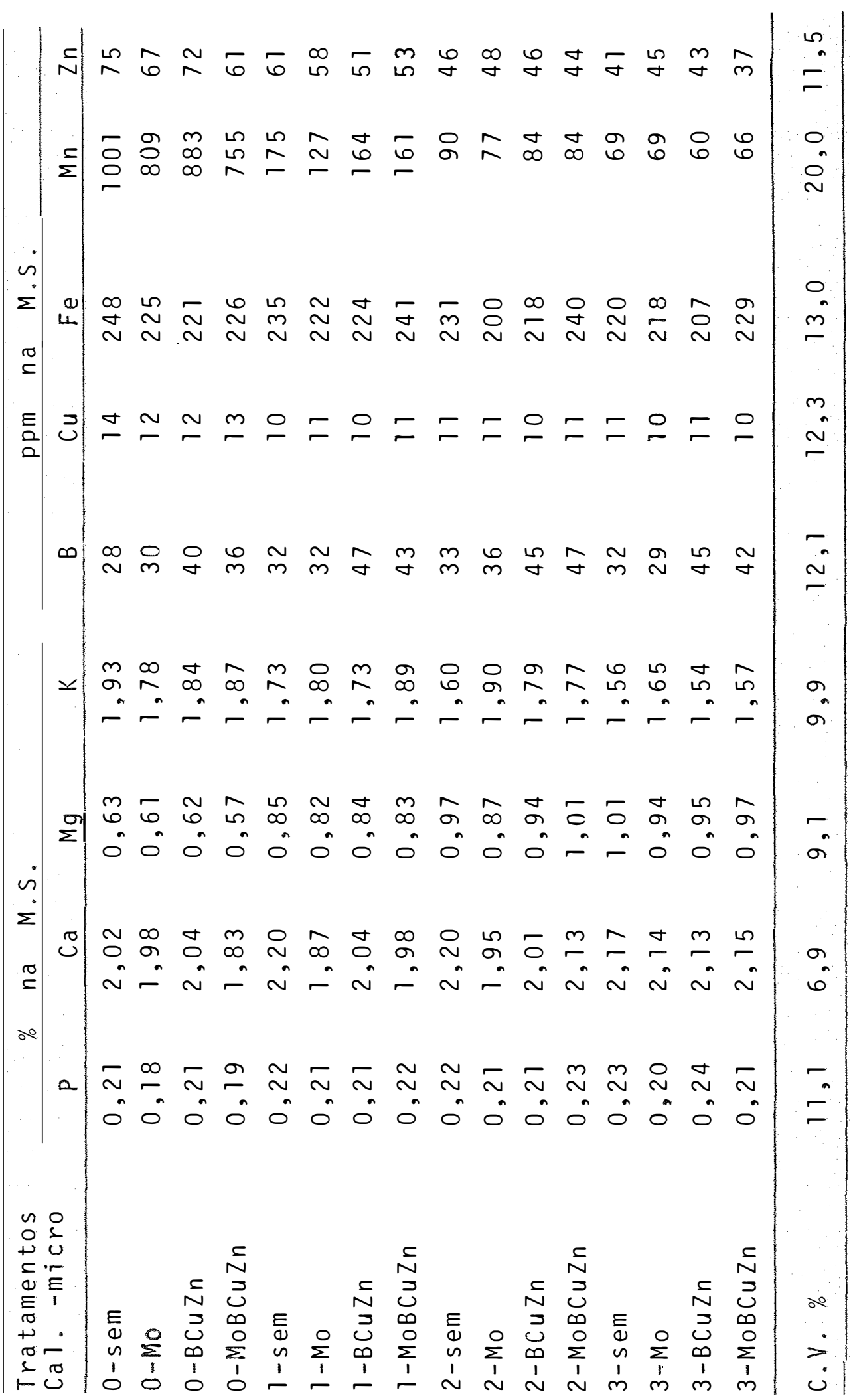




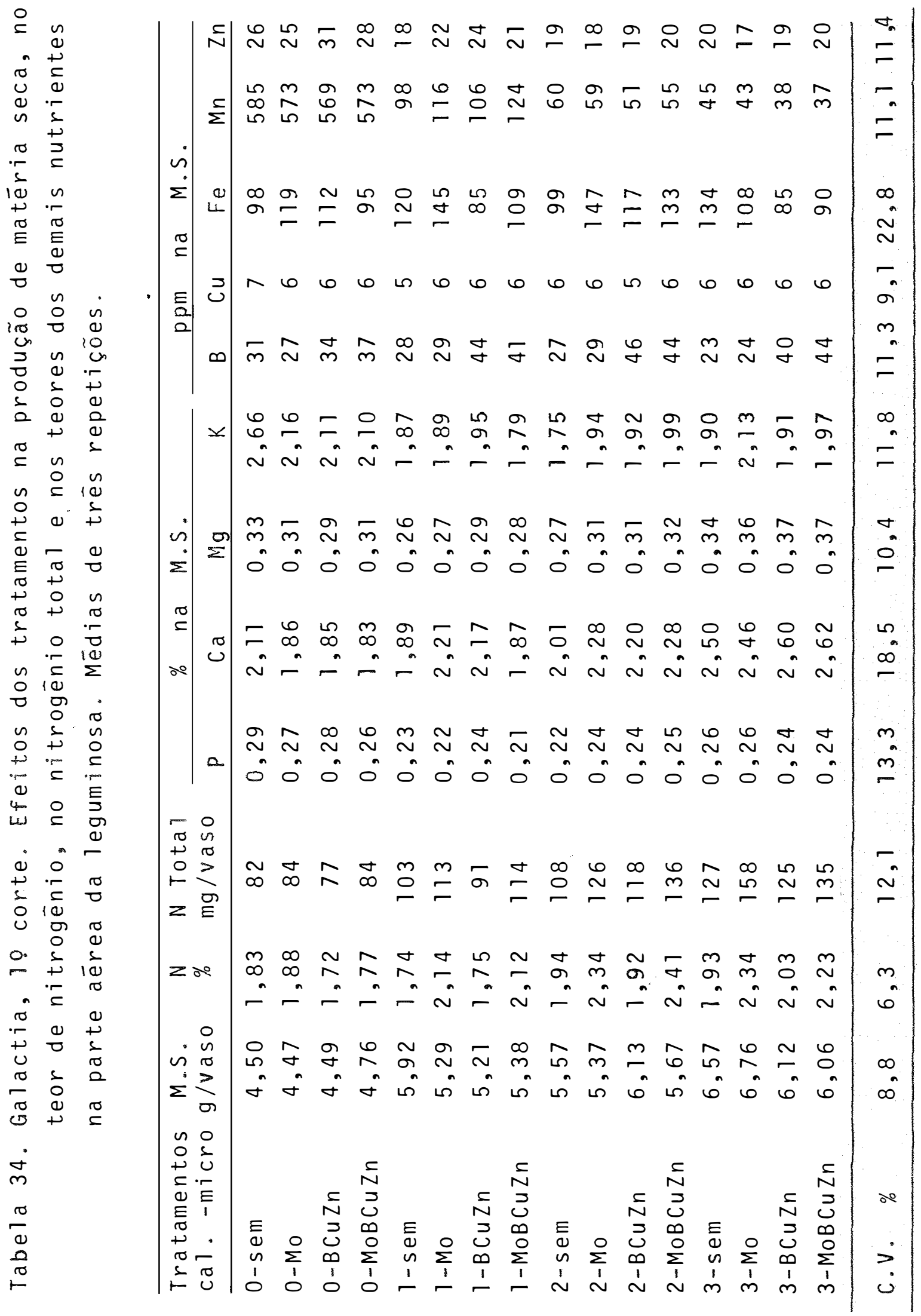




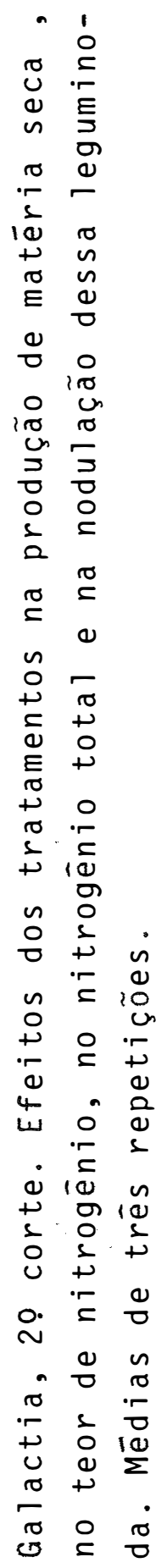

in

0
0
0
0

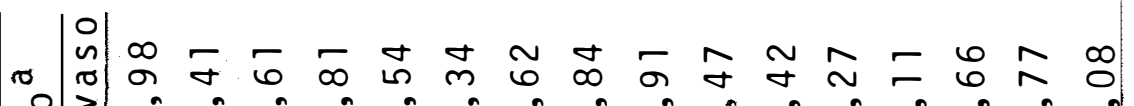

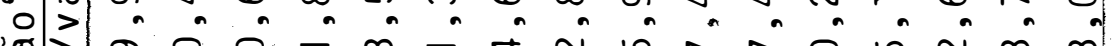

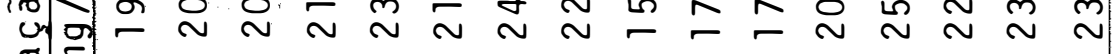
(T) 亏0

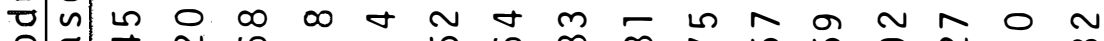

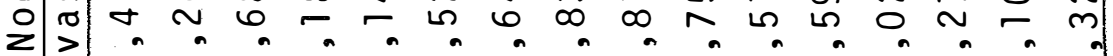

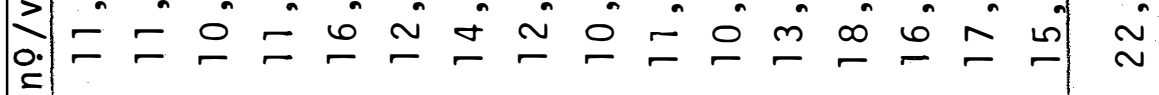

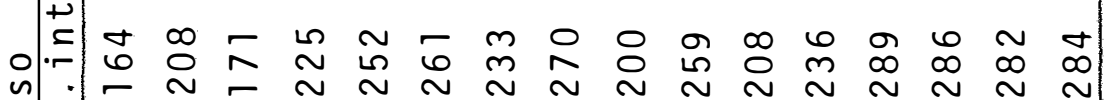
(ึ) $>2$ 애 $N$

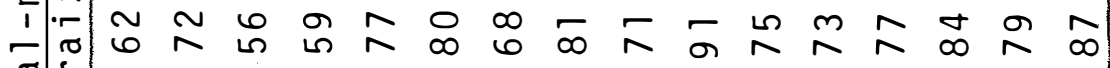
(1)

인.

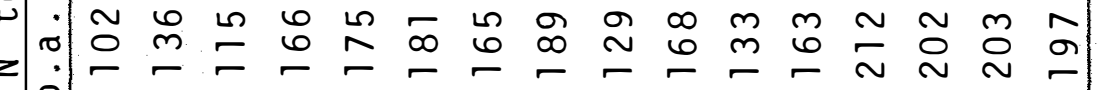
$z$

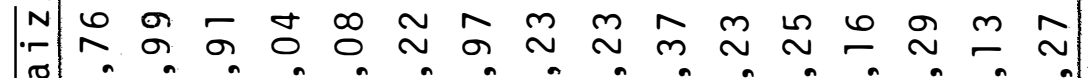

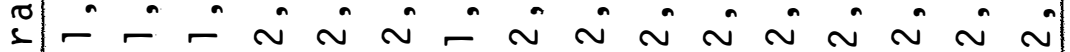
?

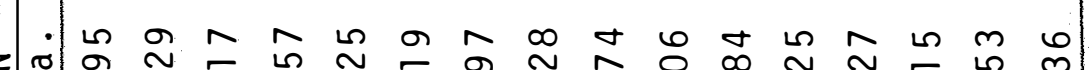

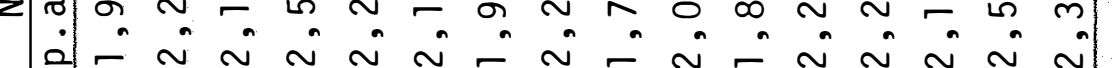

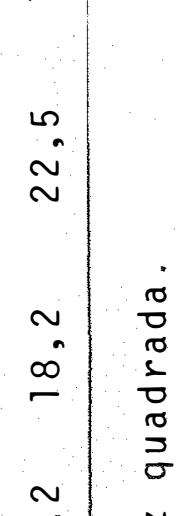
$\stackrel{n}{n} \frac{\pi}{\pi}$ $\infty \quad E$ $\approx$ $n$
0
0
0
$E$
0
0
4
$n$
$c$
0
1

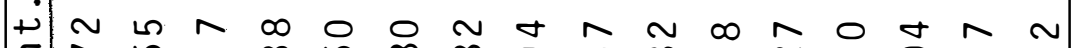

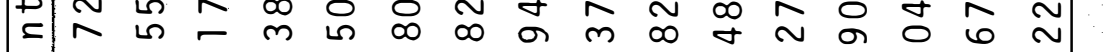

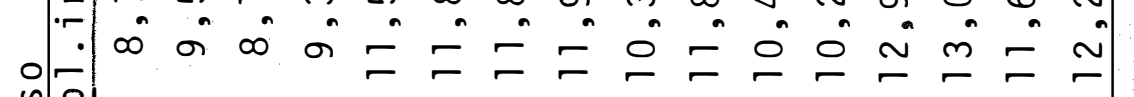
ㄴำ

$\geq$

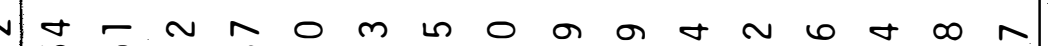

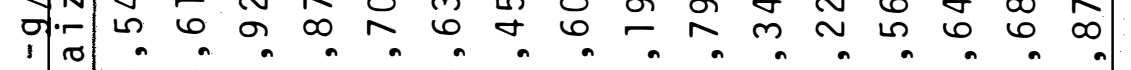
(s)

$\dot{\Sigma}$

$\Sigma$

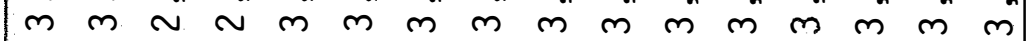

$m($

$-$

$\frac{\pi}{d}$

$\infty \quad \therefore$ - ó $-\frac{1}{2}$

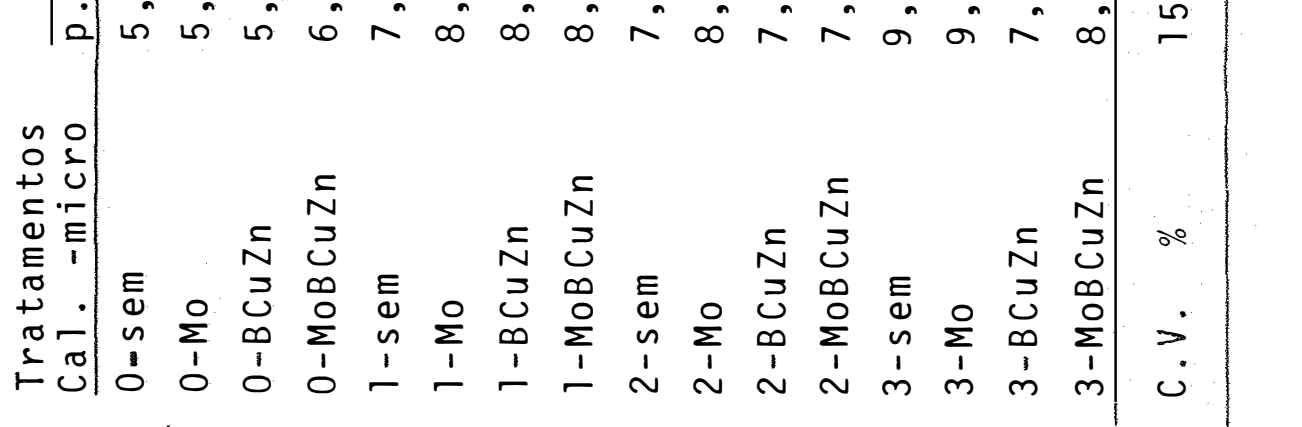


